\title{
7 Philological practices
}

Introductory remarks by the chapter editor, Caroline Macé

Although the stemmatological methodology is not per se restricted to any specific language or period in the history of literature, it has not penetrated every field of textual studies in the same way, and its application has led to various interpretations and evaluations. In the present chapter, examples of the historical development of the stemmatic method, taken from different fields, will be presented. It is, of course, impossible to cover every aspect of textual scholarship, but we hope to provide here a representative sample.

The first section, authored by Christian Amphoux, is devoted to the development of textual criticism in Greek New Testament studies (7.1). Historically, the rejection of the textus receptus of the New Testament may be considered the starting point of a text-critical awareness (Reynolds and Wilson 2013, 209). The difficulties inherent in the very large number of direct and indirect witnesses, and in the high degree of contamination, led to the early development of a specific methodology and of computer tools. The study of the New Testament was a field in which Karl Lachmann, the emblematic historical figure of the stemmatic method, was very active, as much as in classical philology (7.2) and mediaeval German philology (7.4). The two sections devoted to these latter disciplines largely discuss the heritage of Lachmann and the way it was challenged and adapted in the following two centuries. After sketching the history of the Lachmannian method in classical philology, Heinz-Günther Nesselrath shows, referring to a new edition of Lucian of Samosata's work (a Greek-speaking sophist and writer active in the second century CE), the difficulties of understanding the history of this large and complex tradition, represented mostly by late manuscripts (7.2).

As Frédéric Duval shows, mediaeval Romance philology, a domain in which Lachmann did not work himself, was a battlefield between proponents of the Lachmannian method - indeed, the first truly Lachmannian edition was produced by Gaston Paris in 1872 - and its fiercest opponents, such as Joseph Bédier (7.3). Ralf Plate uses editions of mediaeval German courtly epics as an example with which to follow the development of the method and editing techniques in Germanic philology from Lachmann to the present day (7.4).

As an example of philological work on oriental Christian manuscript traditions, Alessandro Bausi shows how philology developed in the field of Ethiopic studies, influenced by classical philology and biblical studies, but also by Romance philology (7.5). Chaim Milikowsky illustrates the different tendencies in editing rabbinic literature since the beginning of the twentieth century, from "best-text" editions to "radical eclecticism"; examples of application of the stemmatic method are very rare (7.6). Christopher Nugent pinpoints some distinctive aspects of the transmission of classical Chinese literature which make it very different from any Western or 
Near-Eastern mediaeval literary tradition (see 1.3), and therefore call for specific editorial responses (7.7).

The gradual introduction of printing technology in Western Europe marks a change of paradigm in the transmission of works. Taking a few Latin examples, Iolanda Ventura shows the methodological uncertainties arising when editing early modern printed texts, whose transmission is still partly conditioned by manuscript culture, but already partly resorts to the field of authorial philology (filologia d'autore), which focuses on authorial variants (7.8). Confronting textual criticism and "genetic criticism", Dirk van Hulle questions the very concept of authorship and of "purity" or "integrity" in contemporary textual scholarship. In doing so, he underlines the differences between several "national" schools within modern textual scholarship (reflecting partly the same "national" schools in mediaeval philology): the Anglo-American, the German, and the French schools, not to mention the Italian variantistica (see 6.2.5). Dirk van Hulle invites textual scholars to distinguish between different possible "orientations to text", which can be combined rather than opposed to one another, and to define different types of editorial strategies (7.9).

It was beyond the scope of this chapter to deal with all languages, periods, or literary genres. Classical Latin is not represented as such, but the situation is relatively similar to that of classical Greek, and several other sections in the book focus on the Graeco-Roman world or on mediaeval or Renaissance Latin. On mediaeval Latin, see, for example, C. Leonardi (1994) and P. Chiesa (2016, 2019). Equally partial is our treatment of the biblical corpus (or corpora), represented only by the Greek New Testament (its many translations into Latin and oriental Christian languages are alluded to), whereas the problems posed by the Hebrew Bible and its numerous translations are different and have not been solved in the same ways (see Tov 1992; B. Chiesa 2000, 2002; for an assessment of the impact of the discovery of the "Dead Sea Scrolls" on textual criticism of the Hebrew Bible, see e.g. Debel 2010). A very large portion of literature in many languages, be it parabiblical or apocryphal, is also neglected. As has been said above, Ethiopic literature is but one example, albeit a significant one, of the very rich and interesting oriental Christian traditions (in Armenian, Christian Arabic, Georgian, and Syriac - to name only some of the most important languages; see 7.5) which developed since late Antiquity (see Bausi et al. 2015). The Byzantine world and the vast continent of the Eastern European Middle Ages have merely been alluded to in other chapters $(3.2,4.5)$. Amongst the Western mediaeval literary cultures, only Romance philology is well represented (also in 2.34), although not so much is said about the Iberian literatures. Early German is dealt with in the present chapter, and alluded to in sections 3.1 and 6.3, whereas languages such as Old English (see 1.5, 6.3), Old Norse (see 6.1), or Old Saxon (see 6.2) are not fully treated. Many other languages are almost totally missing, such as Sanskrit and the vast universe of Indology (see Witzel 2014; see also 6.2.2 above).

A section on textual scholarship in the field of Arabic (Islamic) literature authored by Lucia Raggetti had been anticipated and would have been very welcome 
in the present chapter, but it was withdrawn at the very last moment by its author for unclear reasons and despite all editorial efforts. It would have been interesting to see the turn taken by textual scholarship in Arabic studies, especially after influential voices were raised against the Lachmannian method in that field (see Witkam 1988, 2013). Unfortunately, since this section had to be removed after the book had already been sent to the publisher, it was far too late to find a replacement.

Albeit incomplete, this survey of the impact of the genealogical method in different fields of textual scholarship is important in order to understand how the method has been reshaped differently to respond to different needs. It is also interesting to see how permeable the boundaries between the different disciplines are, and to what extent they have influenced one another in various manners and in different directions, definitely not only from classical philology towards the others, but also in many other ways. An often-mentioned principle should be remembered here: the only criterion for selecting a method is that it should be best suited to its object and to the aim that scholars have set for their work (this aim being shaped by several, sometimes contradictory, needs and constrains). The object varies very much indeed, and that in multiple respects:

- the language can be more or less actively known by the copyists (and even the writer), it may be more or less regulated, more or less artificial, and so on;

- the topic and the literary genre in which the transmitted work is written are of no little importance for the conditions under which it will be transmitted (poetry is not dealt with very much in this book, and nor - at the other end of the literary spectrum, as it were - are technical treatises and so on);

- the type of authorship can vary greatly, as can the involvement of other "textual actors" (see e.g. Schnell 1998 for a discussion of the concept of "author" in the Middle Ages, and P. Chiesa 2012, 381-382, for contrasting antique and mediaeval concepts of authorship); and

- the time gap between the composition of the work and its earliest witnesses is a determining factor in the choice of a suitable methodology, as is the more or less fragmentary character of the remaining tradition.

This list of factors that shape the object of textual criticism is far from being complete. Several publications gather case studies that can fill some of the gaps left by our survey, such as Dummer (1987), Hamesse (1992), Macé et al. (2015), and Göransson et al. (2016). 


\title{
7.1 The New Testament
}

\author{
Christian-Bernard Amphoux
}

The New Testament (NT) is a special case among the transmission of texts from (late) Antiquity because its textual tradition includes thousands of manuscripts and innumerable patristic quotations. Moreover, the Greek text varied a lot from the second to the fourth centuries; it has never been unified, and specialists are today divided on the interpretation of variants: are they "deformations" of a primitive text restored well by the current editors or, in some cases, milestones in a history of the text so complex that current editions are but a temporary solution that can still evolve further? This section provides some information with which to understand what textual criticism of the NT is all about.

The NT was written in Greek, although some of its sources might have been written in Aramaic. It was transmitted in its original language, as well as in about ten other ancient languages into which it was translated. From the beginning of the second to the end of the fourth century $\mathrm{AD}$, the text was unstable, until the time when - from the fifth century onwards - the text established in Antioch became the most widespread, without, however, the previous types of texts disappearing: they remained alive on the periphery of the Byzantine Empire. In the West, the printing press initially favoured the Byzantine text, which was replaced in the nineteenth century by the Alexandrian text. Neither of those texts, however, is "original"; they can both be proved to be the result of revisions undertaken at the beginning of the fourth century. So far, there has been no agreement amongst scholars regarding the details of this history, regarding how to distinguish between the different types of texts, and regarding the chronology.

This section is divided into two parts. First, I would like to present some insights concerning the history of the text, because this reveals much about the history of textual scholarship in modern times. Then, I will explain some of the methods developed over the last century to deal with such a complex textual history and the wealth of variant readings attested by the NT.

\subsubsection{History of the text of the NT}

\subsubsection{A short survey of the manuscripts of the Greek NT}

The NT has come down to us through an exceptionally high number of manuscripts copied from the middle of the second century to the end of the fifteenth century and beyond (see Vagany and Amphoux 1986, 21-84; trans. Heimerdinger 1991, 551; Amphoux 2014, 9-193; Ehrman and Holmes 2013, 1-113). The most important ones can be divided into four chronological categories: (i) papyri copied before 300; (ii) the first Greek Bibles from the fourth/fifth century; (iii) bilingual Greek and Latin manuscripts from the fifth/sixth century; and (iv) mediaeval manuscripts which are 
erratic witnesses to older variants. For a list of manuscripts of the NT and their sigla, see Kurt Aland (1994).

\section{Papyri copied before 300}

These are mainly fragments of books found during excavations in Egypt in the twentieth century. They attest an early form of the Alexandrian text. The most complete are $P^{75}$ (third century, containing Luke and John) and $P^{46}$ (end of the second century, containing the Pauline Epistles).

\section{Greek Bibles from the fourth century}

The first two Greek Bibles (Septuagint + NT), which are also the most important, are the Codex Sinaiticus (N.01), copied in Caesarea around 330, reproducing the recension of Pamphilus of Caesarea, Origen's successor, and the Codex Vaticanus (B.03), copied around 340, reproducing the Alexandrian recension of Hesychius of Alexandria. These two recensions are different but related, and constitute the Alexandrian text of the fourth century.

\section{Bilingual Greek-Latin manuscripts of the fifth/sixth century}

Two bilingual manuscripts witness an old text, in use in the second century, before the other text types: the Codex Bezae (D.05/VL 5), copied around 400, containing the Gospels and Acts, and the Codex Claromontanus (D.06/VL 75), copied in the fifth or sixth century, containing the Epistles of Paul.

\section{Mediaeval witnesses to older variants}

Most mediaeval manuscripts attest the Byzantine text, which is derived from a recension dating from the beginning of the fourth century, that of Lucianus of Antioch. A few of them, however, contain variants that pertain to a more ancient text type, attested by Origen (around 230); amongst them are an uncial manuscript copied in Georgia, the Codex Koridethi $(\Theta .038)$ and families 1 and 13.

As there is no agreement on the genealogy of those text types, I offer here the opinion I have formed on the basis of my own research: the Western text, attested by the bilingual manuscripts, is at the origin of the other text types; the Alexandrian text is derived from it by means of several recensions from the end of the second century; the Byzantine text is the most recent and is derived from a revision of the Caesarean text type, of which many variants are preserved in mediaeval manuscripts, originating with Origen; and the Caesarean text type is itself derived from the Western text through a process of recension.

\subsubsection{The printed editions}

As is well known, the very first book to be printed was Gutenberg's Latin Bible in 1455. It is only half a century later that the first printed edition of the Greek NT was produced (see Elliott 2014). 


\section{The reign of the textus receptus}

The first two editions were produced concurrently in Spain and in Switzerland. Xavier de Cisneros completed the printing of a polyglot Bible in Hebrew, Greek, and Latin in 1514 in Alcalá, although publication proper would occur only in 1522. The edition of the Greek NT prepared by Erasmus in Basle was first published in 1516, and was very well received in the reformed churches, where people would learn Greek in order to access the "original" text of the NT, confidence in the Vulgate having become weak. As early as 1517, Luther's sermons contained a doxology at the end of the Lord's Prayer ("For thine is the kingdom, the power, and the glory, for ever and ever") absent from the Vulgate but present in the Byzantine text which is the basis of Erasmus' edition. By 1535, Erasmus had produced five editions, which were reproduced by other publishers in - among other places - Venice, Hagenau, and Strasbourg (Reuss 1872, 28-31).

In 1534, in Paris, the edition of Simon de Coline was published and served as a basis for the French Bible translation by Pierre Robert Olivétan. This Bible was subsequently revised several times by Calvin in Geneva. Between 1546 and 1550, the editions of Robert Estienne, the printer of the king of France, were published, the last one in Geneva, to which he was forced to flee. In this fourth edition, the text is divided into verses for the first time (the division into chapters had been made for the Latin Bible at the beginning of the thirteenth century by the circle of Stephen Langton in Paris). After Estienne, Theodore Beza, Calvin's successor, published several editions in Geneva between 1565 and 1609, while Plantin printed a new polyglot Bible in Antwerp in 1572. In the introduction to the second edition, published in 1633 in Amsterdam by Elzevir, the expression textus receptus was used for the first time, and became the label for the type of text (Byzantine) printed since Erasmus. As more editions appeared and new manuscripts were consulted, the awareness that the text contained a great number of variants became more and more acute. The first systematic collations of Greek manuscripts of the NT were published in the polyglot Bible of London prepared by Brian Walton (1654-1657). It is not until the eighteenth century, however, that one sees a distinction being made between several recensions (Bengel 1734) and a first ordering of the manuscripts being proposed (Griesbach 1775-1807).

The evidence that eighteenth-century scholars had at their disposal was much scarcer than what we have today: in particular, all the papyri were lacking, since they were discovered in the twentieth century; the Codex Sinaiticus was not found until 1844, and most of the witnesses to the Caesarean type were still unknown; even the Codex Vaticanus, whose existence was known, was unavailable on account of Vatican policy. Although the attempts at classifying the witnesses were flawed by the shortcomings of this documentation, the outline of today's classification was nevertheless already in existence. The outcome of all this was that, until the beginning of the nineteenth century, the textus receptus was considered as the original text of the NT. 


\section{The triumph of the Alexandrian text}

In 1809, consultation of the Codex Vaticanus was made possible in Paris, and the examination of its writing allowed Johann Leonhard Hug to conclude that it was copied before Jerome's revision of the Latin version of the Gospels (Hug 1810). Because of some agreements between the codex and Jerome's revision against the textus receptus, noted by Lucas of Bruges and published in the polyglot Bible of London (1654-1657), the codex had hitherto been suspected of having been influenced by the Vulgate. Hug's conclusions rehabilitated it, and it became the oldest known manuscript of the NT, having already been used in Rome for the edition of the Septuagint (1586). An era of glory began for the manuscript, as from now on it represented the main witness to the Alexandrian text.

In 1831, Lachmann applied to the NT the method used for editing classical texts (Lachmann 1831; see Timpanaro 1981, 53-58). As the principal manuscripts of the earliest times, he chose the following: Alexandrinus (A); Vaticanus (B); Ephraemi rescriptus $(C)$, an incomplete Bible from the fifth century, whose text had been erased and overwritten in the twelfth century with patristic works; Codex Bezae ( $D$ for the Gospels and Acts); Claromontanus ( $D$ for the Pauline corpus); and the Vulgate. The text published by Lachmann was a sensation: it was full of new variants, mainly Alexandrian but also Western, thus highlighting that the textus receptus was not the original text but a relatively late revision. This opened up a new question: how can we reach the oldest form of the NT?

The discovery of the Codex Sinaiticus by Constantin Tischendorf in 1844 sanctioned the importance of the Alexandrian text: this manuscript often agrees with Vaticanus, they are both equally old, and its NT is complete. Some people suspected that the manuscript was a forgery; others believed that it had been revealed by divine intervention so that the faithful could finally know the original text of the NT! Tischendorf's critical edition (1869-1872) contains an Alexandrian text very heavily influenced by this manuscript.

But the "edition of reference" was still to come: this was the one published by Brook Foss Westcott and John Anthony Hort (Westcott and Hort 1881), without a critical apparatus but accompanied by a volume of introduction in which a theory was developed which is still today regarded as valid in the Anglo-Saxon world: the Vaticanus and the Sinaiticus manuscripts represent a "neutral text" dating from the time before the existence of recensions, whereas the other manuscripts depend on three main recensions, detected in the eighteenth century, called "Alexandrian", "Syrian", and "Western". A revision of the official English translation, the King James Version dating from the beginning of the seventeenth century, appeared in the same year, based on the new text and moving away from the textus receptus this revision is the Authorised Revised Version. Conservatives did not accept it, and two different texts of the NT therefore coexist in English: the textus receptus, favoured by the evangelical churches, and the Alexandrian text, of which the new model is very close to the Codex Vaticanus. 
In 1913, the edition by Hermann von Soden cast doubt on the idea of a "neutral text”. Again, three main types of texts were put forward: the Egyptian text, called $H$ after Hesychius, for which Vaticanus and Sinaiticus were the main witnesses; the Byzantine text, called $K$ after the Greek word koine, that is, the common text, the one attested by the majority of manuscripts; and a text called $I$ after the initial of "Jerusalem", a very diverse text that gathers together everything from before the fourth century, that is, material that is now, after the discovery of many papyri, distinguished into the Western and the Caesarean types of texts. In parallel, Caspar René Gregory published a volume of Prolegomena (1894²) to Tischendorf's edition, then Textkritik des Neuen Testaments (1900-1909), which continued the search for NT manuscripts, giving one unique identification number to each manuscript. This directory would be completed by Kurt Aland $\left(1994^{2}\right)$ following the same principles. The preparatory works of von Soden were also published (1902-1910), but he adopted another system of numbering the manuscripts which makes it difficult to use his edition today. Von Soden's merits must be acknowledged, however, since he made many fresh collations of manuscripts and recognised the existence of a multiform text prior to the text of the Codex Vaticanus and the Codex Sinaiticus.

This, however, could not change the powerful trend of editing the Alexandrian text, and editors would simply ignore other works and continue favouring the Vaticanus and Sinaiticus text as the basis for editions of the NT. It was in vain that several scholars highlighted the anteriority of the Western text to the Egyptian one, and also questioned the position of the Caesarean type. The new critical editions that were undertaken - those by Stanley Charles Edmund Legg (1935, 1940; Mark and Matthew respectively) and then by the Institut für neutestamentliche Textforschung in Münster (Catholic Epistles: B. Aland 1997-2005), but also that by Reuben Swanson (1995-2005; Matthew to Galatians) - all of them partial, favoured the Alexandrian text. The only exception is the International Greek NT Project (1984-1987; Luke), which chose to edit the textus receptus again. In actual fact, the making of a critical edition of the NT is rendered difficult because of the tension between the critical examination of the variant readings, on the one hand, which leads to priority for the Western text, and, on the other hand, the older age of the witnesses to the Alexandrian text, reinforced by the discovery of papyri copied around 200. The Western text, even though it is older, is not attested in its entirety and, more importantly, it is not suitable for use in churches: it is an old scholarly text which has been in decline since the end of the second century; it was not read or commented on in Antiquity, and had almost completely disappeared by the Middle Ages - it would make no sense to give it priority today in church use. On the other hand, the Caesarean type of text is not completely known either, because its witnesses are late and all contaminated by the Byzantine text, which was initially a revision of it. In comparison, the Alexandrian text, with its two main witnesses, the Codex Vaticanus and the Codex Sinaiticus, is complete, even though these two witnesses reflect an attempt, which would be abandoned and replaced by the Byzantine text, to construct a model for copying the Greek Bible. 


\subsubsection{How to deal with the variant readings}

Because of the number of manuscripts and of variants and the even higher number of lost intermediaries, but also because of the nature of the transmission of the text, which occurred through a series of successive revisions, the Lachmannian method today seems impracticable for NT textual criticism, especially because of the contamination from the Byzantine text. Only for small groups of manuscripts is it possible to propose a stemma codicum, as, for example, in the case of family 13, which includes a dozen manuscripts of the Gospels all copied in southern Italy (Lafleur 2013, 158-241). The possibility of using statistical, and later automated, methods may change this situation, but so far the results obtained by those methods have not proved to be any better than a philological examination of the variants one by one. In what follows, we will present first the philological method applied to the NT, and then several attempts at using automated means to treat the variants of the NT.

\subsubsection{Philological examination of the variant readings one by one}

For the NT, the method that has been used and refined over time to deal with variant readings is divided into three successive steps.

\section{Verbal criticism}

The first step consists of looking for mistakes arising from the copying process, with the aim of eliminating them from the text. In practice, these mistakes have been removed in the standard editions (Nestle-Aland, Novum Testamentum Graece, 28th ed. 2012; B. Aland et al., The Greek New Testament, 5th ed. 2015) but are not fully documented in the critical apparatuses, which are incomplete; in more advanced editions (von Soden 1913; Legg 1935, 1940; Swanson 1995-2005), on the other hand, the documentary basis is greater but much still needs to be done as far as verbal criticism is concerned.

Some types of variant readings can be quite easily eliminated.

- Orthographical errors (deviating from the established rules for standardisation of written Hellenistic Greek).

- Haplographies or dittographies (i.e. omitting or repeating a syllable or a word).

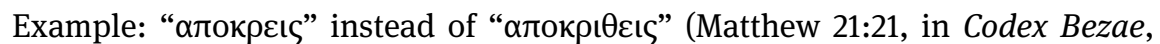
f. 70v, line 1; cudl.lib.cam.ac.uk/view/MS-NN-00002-00041/126).

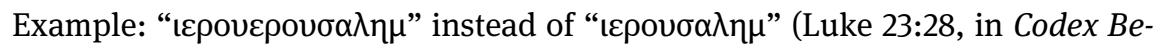
$z a e$, f. 278v, line 17; cudl.lib.cam.ac.uk/view/MS-NN-00002-00041/537).

- Homoeoteleuton or homoeoarcton (i.e. omission of a group of words because of the similarity of letters at its beginning and end, causing the eye to jump; see 4.3.2).

Example: this type of mistake is found very often in the Codex Sinaiticus (codex sinaiticus.org/en/manuscript.aspx), where omitted passages are supplied in the margins. 
- "Harmonising” variants, especially in the Gospels: a passage in one Gospel is made closer to the parallel passage in another Gospel.

Example: in Mark 6:3, Jesus is called "o $\tau \varepsilon \kappa \tau \omega \nu$ " [the carpenter], but in a few

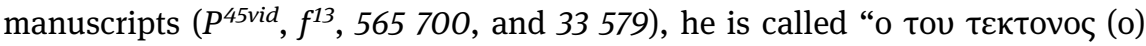
vio૬” [the carpenter's son], in accordance with Matthew 13:55.

All these variants, because they are unintentional, can be left out of the apparatus, whereas those that are intentional should be noted in the apparatus. In practice however, except for obvious writing mistakes, it is generally hard to say whether a variant is intentional or not, and most cases will need to be carefully examined.

\section{External criticism}

This analysis consists of gathering all existing information concerning manuscripts and text types, in particular their dates and locations. It is important to bear in mind that the time when a manuscript was copied and the date of the text it contains are not necessarily the same. For example, patristic quotations allow the Western text contained in the Codex Bezae (D.05), which was copied around 400, to be dated at least to the second century. On the other hand, the Alexandrian text of the first papyri, copied between 180 and 230, is not attested before 175. Therefore, for the text of Luke, for instance, the Codex Bezae offers an older text than papyrus $P^{75}$ and is very close to the Vaticanus text (Duplacy 1973, 111-128).

This external criticism leads to the following conclusion: the Western text, attested essentially by the Codex Bezae but also by second-century citations, and to a lesser extent by the Old Latin and Syriac translations, existed before the Alexandrian text, which in turn predates the Byzantine text that took shape during the fourth century. On the other hand, since the Western text is attested in regions that are far away from each other, it has been considered "universal" (Vaganay and Amphoux 1986, 160-161; trans. Heimerdinger 1991, 110), whereas the Alexandrian text is present mainly in Egypt, and the Byzantine text, as its name suggests, in the Byzantine Empire. But these conclusions remain hypothetical because the fact that a text is attested in an older witness does not mean that the text is genealogically older. To settle the question, it is necessary to carry out an internal analysis of the variants.

\section{Internal criticism}

This type of criticism is divided into two aspects: (i) a search for the variant-source (or primary variant) by comparing all variants found at one locus, and (ii) an examination of how those variants fit into their context.

(i) Searching for the source-variant

The central issue is to determine, if several variants occur in one place, in what order they came into existence. Some of the criteria developed to answer this ques- 
tion go back to Gerardus de Trajecto Mosae (Gerard of Maastricht) in his 1711 edition of the NT (Vaganay and Amphoux 1986, 121-122; trans. Heimerdinger 1991, 79-80), the most important ones being brevior lectio probabilior (the shortest reading is the most probable) and difficilior lectio potior (the most difficult reading is preferable). In other words, experience shows that copyists tend to expand the text rather than shorten it, and to make it simpler rather than complicate it. Here are two examples of those principles.

- Mark 1:41: a leper asked Jesus to cure him, and in some manuscripts Jesus got

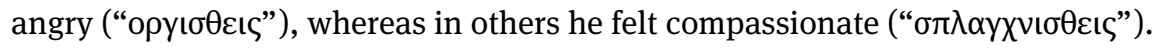
Regardless of the manuscripts in which it appears, the first variant seems more difficult to understand in the context, and it must therefore be the primary reading.

- Luke 11:2-4: some manuscripts offer a "complete” Pater noster with seven requests, whereas others attest a shortened prayer with a shorter address and only five requests. According to the principles stated above, the shorter version must be primary.

But these principles alone are inadequate, and the choice of the primary variant should always be justified by stronger arguments. In Mark 1:41, one has to interpret Jesus's anger: it is possible to read the passage in such a way that Jesus is not angry at the leper as a sick person, but at a group of people whom the leper represents and of whom Jesus disapproves. As for Luke 11:2-4, Tertullian states that the shorter version of the Pater noster in Luke was revised by Marcion (Tertullian Adversus Marcionem 4.26.1-4; Harnack 1924, 207^; Amphoux 1987, 106, 110). Marcion published his revision of Luke around 140, and he suppressed many passages. Is it therefore possible that he shortened the Pater noster, too? And if so, what did he want to suppress from the original prayer?

In the Gospels, many variants are "serious" in the sense that they present difficulties such as those in the two variants presented above. Many more variants are "slighter", however, as they have less impact on the meaning of the text and are therefore less interesting. Those "minor" variants have to do with grammar and literary style, and most of them are due to the copying process, in which the copy is never completely identical to the model (Dain 1964, 30-37; Amphoux 2014, $12-$ 15). In all cases, the point of comparing the variants found at any one place is to determine the source-variant, that is, not the variant attested by the oldest witnesses but the variant from which all the others can be explained.

(ii) Appropriateness to the context

The search for the source-variant leads to one or more possible solutions, and it is necessary to verify the hypotheses by testing them against the context of the variants, this context being immediate or wider.

To provide just one example: in Mark 1:41, which we examined above, Jesus's anger occurs in an immediate context, where Jesus "blames" the leper (verse 43) 
and shows hostility towards him, which is not found in the parallel passages. But this still does not explain what the leper represents in the passage. To understand this, one must look at Leviticus 13-14, where leprosy is considered the sickness of impure priests. So, the leper in Mark 1:41 represents a category of employees of the Temple with whom Jesus is angry. This metaphorical meaning of the leper, being too complicated, was abandoned in some manuscripts by changing the word for "angry" into that for "compassionate".

This example, and many others which we could mention, reveal a new issue in the history of the NT text, an issue that is often ignored by exegesis: the NT text may have had other meanings in the course of time than that which has been transmitted. This also shows the complexity and the importance of applying textual criticism to the NT.

Given this complexity, is it possible to treat the variants automatically?

\subsubsection{Towards an automated treatment of the variant readings (Pastorelli 2014)}

In 1742, Johann Albrecht Bengel was the first to try to classify the manuscripts of the NT according to their variants and to establish significant groups of manuscripts, which would later become the witnesses of the various "recensions".

\section{Quentin's method}

In the 1920s, Henri Quentin (see 2.3.4) applied to the manuscripts of the Vulgate a new method, in which the number of common variants between manuscripts is compared using groups of three manuscripts: if two manuscripts have no (zero) agreement against a third one (what Quentin called the "zéro caractéristique"), then this third manuscript must be either an intermediary between the two or their common ancestor. This method, based on numbers and not requiring any philological analysis of the variants, was a first step towards systematisation and, ultimately, automation of the processing of variants.

\section{Multiple Readings Method (Colwell)}

In 1947, Ernest Cadman Colwell rejected the use of the genealogical method for the NT, using tables of variants to group manuscripts instead, and especially seeking to add other manuscripts to already existing groups as defined by previous research. This method has been applied with success by several scholars, among whom are William L. Richards (1977), Larry Hurtado (1981), and Eldon J. Epp and Gordon D. Fee (1993). See also Jean Duplacy (1975).

\section{Claremont Profile Method (CPM)}

With the arrival of computers, the Multiple Readings Method (Colwell 1969) gave birth to the International Greek NT Project, aimed at providing a critical edition of 
Luke (1984-1987) based on 1,666 Greek manuscripts. Starting from base manuscripts that had already been classified, a number of characteristic variants for each group were selected, and each new manuscript was classified on the basis of these variants. This method is useful for rapidly grouping the Byzantine manuscripts, but it does not allow us to see if, among the variants, some manuscripts shift from one group to another.

\section{Comprehensive Profile Method (Ehrman)}

In 1986, Bart Ehrman refined the Claremont Profile Method and distinguished several categories of variants: (i) distinctive readings, attested by most witnesses of one group and only by them; (ii) exclusive readings, attested by at least two witnesses of one group and only by them; and (iii) primary readings, attested by witnesses of several groups. This method was applied successfully to the Gospel quotations of Didymus the Blind; then by Darrell Hannah (1997) to the quotations of the First Epistle to the Corinthians in Origen; by Roderic Mullen (1997) to the Gospel quotations in Cyril of Jerusalem; by Jean-François Racine (2004) to the quotations of Matthew in Basil of Caesarea; by Carroll D. Osburn (2004) to the quotations of Acts and the Pauline and Catholic Epistles in Epiphanius of Salamis; by Carl Cosaert (2008) to the Gospel quotations in Clement of Alexandria; and so on. It is apparent that this method is used to classify quotations rather than manuscripts.

\section{Index of variation (weighting variants)}

To take account of the relative importance of textual variations, I proposed an "index of variation" which I applied comparatively to the method of Quentin and to data analysis by computer (Amphoux 1988). This index gives more weight to lexical substitutions than to transpositions, and to substitutions of verbs or substantives than to those of prepositions or conjunctions. The results were promising, allowing a better classification of the manuscripts, but a huge amount of interpretation remains to be done by scholars, and this index should be further developed and finetuned.

\section{Coherence-Based Genealogical Method (Mink)}

Finally, in 1993, Gerd Mink set out to adapt the method of the stemma codicum to the Gospel manuscripts by establishing one $\mathrm{sub}$-s te m ma for each variation unit, and then automatically gathering all sub-stemmata into a "textual stream" (see 5.3.7.3 above). This idea is very appealing, because, as I have shown above, the processing of variants in the NT is complicated by several phenomena. But the results are disappointing: used in Münster for the Editio critica maior of the Catholic Epistles, it led to the reproduction, with very few differences, of the edition of Nestle.

In short, all those formal approaches have as their point of departure the premise that the evolution of a text can be reduced to formal questions. Indeed, to a 
large extent, minor variations can be dealt with in such a way, and for them formal approaches may prove useful. As for major variants, however, it is necessary to approach them with the type of philological examination that I have elucidated above.

\subsubsection{Implications}

Scholars working on the NT face a contradictory situation: on the one hand, the NT, as a reference for Christian faith, needs to be edited as a fixed, non-fluctuating text; on the other hand, the history of this text is such that it has in reality changed considerably over the course of time, precisely because it was a reference text at the centre of ecclesiastical, liturgical, and dogmatic rivalries. It is therefore impossible, in view of the documentation that we have, to offer at the same time a unified text and its oldest possible state. As a result, the edited text can only be a compromise, and several solutions are possible. Most scholars nowadays tend to give preference to the text of the Greek Bibles from the beginning of the fourth century. Other scholars would rather go back to the Byzantine text, which was the most widely read in the Greek world in the Middle Ages - a solution close to that proposed by the supporters of the textus receptus. Personally, I am in favour of an edition that would show several - at least three - states of the text synoptically: the Western text above, and the Alexandrian and Byzantine texts in two columns below, with a critical apparatus gathering the main variants at the bottom of the page.

\section{Acknowledgements}

The author would like to thank Caroline Macé and Jenny Read Heimerdinger (University of Wales Trinity Saint David) for their help in translating this text into English, as well as David Pastorelli (Université d'Aix-Marseille) for suggesting additional bibliographical references.

\section{Further reading}

To learn more about the classification of the NT manuscripts and about the specific problems caused by the overabundance of documentation, see Duplacy (1975) and Pastorelli (2014). Interesting recent contributions are, for example, van Reenen, den Hollander, and van Mulken (2004); Carlson (2015); Gurry (2017); and Wasserman and Gurry (2017). 


\subsection{Classical Greek}

Heinz-Günther Nesselrath

Until recently, in the field of classical philology, the Lachmannian method had been almost unchallenged, at least in theory, since its invention. After a historical introduction to the development of the Lachmannian method, and some considerations about the challenges faced when applying this method to real cases, I will focus on a specific example, that of the edition of Lucian of Samosata's work, which poses particular problems in Greek philology.

\subsubsection{The development of stemmatology in Greek and Latin classical philology}

In the field of Greek and Latin classical philology, stemmatology is closely associated with (if not in fact identified by) what is commonly called "Lachmann's method" (on the emergence of the term, see below). It is therefore all the more remarkable that Karl Lachmann (1793-1851) - who was not only a classicist but also an editor of mediaeval and modern German texts - was, in many of his editions (of Propertius, 1816 and 1829; of Tibullus, 1829), not "Lachmannian" at all (see Timpanaro 2005, 76-79; Trovato 2017, 83), and that his edition of Catullus of 1829 was based on a mathematical reconstruction of the archetype that was, even quite recently, severely criticised by Fiesoli (2000, 61-85). In other editions, however, like those of the New Testament (editio minor, 1831; editio maior, together with Philipp Buttmann, 1842-1850), Lucretius (1850), the Nibelungenlied (1826), and other Middle High German poems (1820s-1840s), he at least came close to the methodological approach which later received his name. His New Testament edition is not to be noted so much for its improvements to the text as for being the first to abandon the old textus receptus (established by Erasmus in the early sixteenth century; Fiesoli 2000, 147; see also 7.1 above). Even his highly acclaimed edition of Lucretius ("an dem wir alle die kritische Methode gelernt haben" [using which we all have learned the critical method]; von Wilamowitz-Moellendorff 1921, 59) exhibits errors in methods of judgement (Fiesoli 2000, 257), and in his editions of Middle High German texts he more than once proceeds with a "Bédierist" (see below) preference for just one manuscript (Fiesoli 2000, 289, 295, 302, 329).

Timpanaro has pointed out that Lachmann had important predecessors - in the fifteenth century the Italian humanist Angelo Poliziano, in the eighteenth century the New Testament editor Johann Albrecht Bengel (the discoverer of the principle of lectio difficilior) - and that Lachmann's contemporaries, among them the Danish classicist Johan Nicolai Madvig and the Jewish German classicist Jakob Bernays (who published his own Lucretius edition in 1852), did fundamental work with regard to establishing stemmata codicum and reconstructing archetypes (Timpanaro 2005, 46-74, 97-98, 104-106; see also Kenney 1974, 103-105). 
The most basic principle of the "method of Lachmann" - that, for establishing the relationships between manuscripts (as a precondition for the construction of a stemma), "what is significant [...] is not agreement in true readings [...], but agreement in readings of secondary origin, namely corruptions and emendations, provided that they are not such as might have been produced by two scribes independently" (West 1973, 32; see now Trovato 2017, 54-56, 109-117, insisting on the importance of distinguishing between "mere" variants and significant or indicative errors) was not formulated (or even consciously applied) by Lachmann but by textual critics in the second half of the nineteenth century. According to Michael Reeve (1998, 68), Gaston Paris deserves the "title of the first scholar to have applied systematically the principle that only shared errors establish families of textual witnesses; and the first explicit formulation remains Paul Lejay's in 1888" (see also 2.3 above). However basic this principle is, even in recent times there have still been editors who (though claiming to use the stemmatological method) have not applied it consistently enough (see Reeve 2000, 201-202).

All in all, it is quite ironic that the "method of Lachmann" received its name from the anti-Lachmannian Bédier (see P. L. Schmidt 1988) and from others who criticised the method (Quentin, Greg, Pasquali; see Fiesoli 2000, 355-452).

\subsubsection{Challenges of the method: Contamination, interpolation, Bédier's optimus codex}

If the transmission of texts proceeded only in single "vertical" lines (producing new copies of a text by using just one older manuscript as exemplar), the stemmatic method would work perfectly well; however, the phenomenon of "contamination" (i.e. using more than one source of textual information, be it another manuscript or additional variants recorded in the margins or above the lines of the exemplar manuscript) can all too easily blur the picture and obscure relationships between manuscripts (see 4.4). Already in 1926, Paul Maas concluded: "Gegen die Kontamination ist kein Kraut gewachsen” (Maas 1960, 30) [No specific has yet been discovered against contamination] (trans. Flower 1958, 49). And contamination seems to be a more widespread phenomenon than stemmatologists would like. On the other hand, as Michael Reeve $(1986,39)$ pointed out, stemmatology is the one method that helps us detect contamination, and thus it should still be possible to discover "basic" relationships between manuscripts, even if contamination has caused some disturbances. In any case, the presence of contamination is a major obstacle "for the automatic generation of stemmata used in computer-assisted philology" (Trovato 2017, 136; see also below).

In the early twentieth century, Joseph Bédier (1864-1938; see 7.3), after initially following the stemmatic method (in his first edition of the Lai de l'ombre in 1890), became its most vehement critic and began to champion a radically different ap- 
proach, that is, the privileging of the optimus codex. First in his new edition of the Lai de l'ombre in 1913, and then in a substantial article, "La Tradition manuscrite du Lai de l'ombre: Réflexions sur l'art d'éditer les anciens textes” (1928), he pointed out what is still known as Bédier's paradox: the fact that, of all the stemmata editors have drawn up following Lachmann's method, a suspiciously high percentage are made up of bipartite stemmata (i.e. ones consisting of only two main branches), resulting in an unnatural forest of only bifid trees. From this, Bédier inferred that "Lachmannian" scholars somehow - perhaps unconsciously, perhaps also because something is wrong with the method - interpreted the evidence of their stemmatological research always (or almost always) in such a way as to arrive at bipartite stemmata, which then would give them a choice between two variants found in the two branches (while, with more branches, the variant found in the majority would always have to be chosen as representing the archetype).

In the course of the twentieth century, a number of scholars have tried to grapple with Bédier's paradox. Giorgio Pasquali downplayed the high number of bipartite stemmata and confidently asserted that any number of "three-, four-, fivebranched stemmas" (1934, 130-131) could be found; he did not, however, repeat this argument in later publications because, even among editions of classical texts, bipartite stemmata represent a clear majority, as Arrigo Castellani also had to admit in 1957 (see Timpanaro 2005, 159-160). In 1986, Michael Reeve expressed his continuing confidence in the stemmatic method:

I believe that pluripartite stemmata are commoner among classical Latin texts than he [Timpanaro] allows; that Greg's hypothesis of decimation has not been refuted, though it will never be confirmed (or for that matter refuted) by purely mathematical calculations; that many bipartite stemmata are both textually and historically as certain as one can hope; that [...] interpolation is a more frequent cause of false bipartite stemmata than contamination; and that stemmatic method remains valid. (Reeve 1986, 69)

Recently, Paolo Trovato (2017, 85-93) has drawn attention to a solution to Bédier's paradox provided by Weitzman (1987), whose mathematical model "indicates a $77 \%$ probability for two-branched trees for Greek texts, and $71 \%$ for Latin texts” (Trovato 2017, 89). Trovato sees this confirmed by his own research. He also very pertinently points out that reconstructed stemmata are of course not "accurate depictions of the historical vicissitudes of transmission" (Trovato 2017, 144), because they can only take account of witnesses of a text that still exist (and not of the possibly many more lost ones, which, if still extant, might significantly alter a stemma). A quarter of a century earlier, James Grier had, in fact, already found some advantages in the possible over-representation of bipartite stemmata as a result of the stemmatological method:

The key issue [...] is the question of reasonable competing readings [...] If the bipartite stemma is preferred in each case, this category is enlarged considerably and so too the number of readings on which critics must exercise their judgement and decide on the basis of their interpretation [...]. This is the procedure Lachmann hoped to avoid. The alternative, however, is 
even less attractive: that is to elevate some of those readings [...] to the level of certainty by eliminating their competitors and there can be no doubt that, among those so elevated to the archetype, some will be false. (Grier 1989, 274)

And he goes even further:

My conviction is that, if the stemma is determined on textual grounds alone, no multipartite divisions and no codices descripti should be accepted at any level. My guidelines will thus result in a more responsible application of Lachmann's method. Even if the proposed bipartite relationships are false, they do not eliminate good readings, only those that would have been eliminated in any event by a true multipartite stemma. (Grier 1989, 277)

In this way, Bédier's argument - that editors proceeding according to Lachmann's method subconsciously (?) want to preserve their freedom to choose between readings - is actually turned on its head.

There is yet another challenge to the stemmatological method. In recent decades, attempts have increasingly been made to involve computer programs in the critical editing of texts; preliminary stages to these attempts can be seen in the work of two Benedictine monks, Henri Quentin in the 1920s and Jacques Froger in the 1960s (see 2.3). Like Bédier, Quentin impugned the common-errors method and chose to speak only of "variants"; Froger built on this idea and tried to pave the way to automated coverage of all variants. Within the field of Greek and Latin classical philology, such approaches still face major scepticism and, it seems, justifiably so. Michael Reeve $(2000,345)$ has cited an example of an edition of a Latin text which used the computer for collating thirty-seven manuscripts, but took more than twenty years to do so and still left more than fifty manuscripts out of the picture. In many cases, the texts of classical authors are transmitted by considerably fewer manuscripts, and in such cases computers may not really seem necessary to do the required collating. It is, however, not to be denied that digitisation can nowadays make excellent reproductions of manuscripts available (they can - thanks to the possibilities of magnification - even be clearer to read than the originals); I have myself greatly benefited from this technology for the production of a new critical edition of the Emperor Julian's writings from the time of his sole reign. In any case, Trovato $(2017,246)$ has well pointed out the limitations of computers for editorial work: "there are stages in editorial work that are not mechanical or serial, and hence cannot be delegated to machines", and even the distinction between what are "good" or "corrupt" readings can only be made by human minds, which will only change when an artificial intelligence of such capacity is developed that it will probably replace human dominance on this planet.

\subsubsection{A concrete example of a stemmatological challenge: (Re)constructing a stemma for a new critical edition of the works of Lucian of Samosata}

In my current project of re-editing the works of Lucian of Samosata for the Oxford Classical Texts series (OCT), I myself face the limitations of the stemmatological 
method discussed above (the possibility of an "open recension”, a not fully satisfactory bipartite stemma, the presence of "contamination").

The last OCT critical edition of Lucian (by Matthew D. Macleod, 1972-1987) is based mainly on the results of an enquiry by Karl Mras (1911) into the transmission and manuscripts of Lucian that, at the time of Macleod's edition, was already more

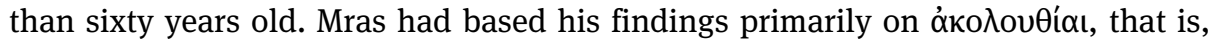
the sequence of Lucianic works in the manuscripts, which he used to establish lines of kinship between them, as a result of which he posited two families (thus, we have a bipartite stemma again), $\beta$ and $y$ - which, however, were not coextensive (i.e. family $\beta$ comprised considerably fewer works than family $y$ ) - as well as a class of codices mixti. Even very soon after Mras, however, Bruno Keil (1913, 512n1) pointed out that certain lines of dependence can only be established by the comparison of textual readings and variants. More recent editions of single Lucianic works (Coenen 1977; Itzkowitz 1986, 1992) have collated afresh all possibly relevant manuscripts and thus come to results that are at least partially different from Mras's findings. Moreover, shortly after Mras, another scholar, Hermann Wingels (1913), came to some rather different conclusions regarding the way the Lucianic œuvre came together: Wingels believed that the two main manuscript traditions observable in the transmission of Lucian came about not by the purposeful work of individual redactors (as Mras believed), but by the gradual accumulation or fusion of smaller editions of single or a few works.

In the case of a number of Lucian's works, these different perspectives have led to some disagreement over whether the transmission really took place in two distinct families or not. Thus, Mras and Macleod believed that for works 32 (Somnium) and 53-54 (Tyrannicida, Abdicatus) - the numbers are given here according to the sequence in one of the main Lucian manuscripts, Città del Vaticano, Biblioteca Apostolica Vaticana, Vat. Gr. $90(\Gamma)$, which has become the basis for the arrangement of Lucian editions since the early twentieth century - a double tradition exists. According to Wingels, however, there is only a single tradition for these works. In the case of works 36 (De mercede conductis) and 39 (Asinus), Mras himself was unsure whether there were two traditions or just one, while Macleod posited one. Coenen (1977, cix-cx) pointed out that in works 15-19 (De calumnia, Lis consonantium, Symposium, Soloecista, Cataplus) and 25 (Timon), the differences between the two manuscript families ( $\beta$ and $y$ ) are much smaller than elsewhere; in works 52-54 (Deorum concilium, Tyrannicida, Abdicatus), he sees so little difference between them that it becomes unclear whether their manuscripts can be divided into two different families at all.

All these results tend to favour Wingels's thesis that the two corpora (which then became two families) grew only slowly over time and that their earliest parts probably exhibit the biggest differences. Furthermore, in those cases where only a single family seems to be extant, it is not always clear to which of the two mentioned families the works in question belong: works 1-12 are found in the namesake 
of the $\beta$ tradition, $B$ (Wien, Österreichische Nationalbibliothek, phil. gr. 123), which is a composite manuscript assembled (it seems) from groups belonging to the two families; but where did the switch occur, before works 1-12 or after them? This is not an idle question, because the two traditions - where they can be found in one and the same work and are clearly distinguished by variae lectiones - exhibit some remarkably different features: $\beta$ seems more prone to "editing" or tampering with the text than $y$; thus, the question of whether a given work belongs to the $\beta$ or the $y$ tradition may be important for deciding whether a reading is a faithful witness to an original tradition or might have been subsequently changed by an editor.

There also remain further questions about the internal "set-up" of the two families which cannot be treated in detail here, but which suggest that relations between manuscripts may really vary from work to work and thus make it difficult to come to more general conclusions covering the whole corpus (or even large parts of it).

As one can see, the open questions regarding the tradition and textual history of Lucian's works are still considerable; but I am fairly confident that patient and consistent application of the stemmatological ("Lachmann's") method should help to obtain answers.

\section{Further reading}

Apart from West (1973), which is a good introduction to textual criticism in the field of classical philology, Bernabé and Hernández Muñoz (2010) deal specifically, and in a more practical way, with Greek classical and mediaeval texts. A new Oxford Handbook of Greek and Latin Textual Criticism should appear soon (de Melo and Scullion forthcoming).

\subsection{Mediaeval Romance Philology}

Frédéric Duval

Mediaeval Romance philology occupies a central place in the debates that have left their mark on the history of textual editing from ca. 1870 until the present. This can be explained by the richness of literature from mediaeval France (both in langues $d$ 'oil, $R$. and Occitan), which is an inevitable meeting point for mediaevalists, not only from French-speaking countries. Through them, Romance philology has exerted some theoretical and methodological influences on other linguistic and cultural areas and, in turn, has received elements from other traditions. The stemmatic method has been at the core of these debates since the edition of the Vie de Saint Alexis by Gaston Paris (Paris and Pannier 1872).

The present section follows a chronological order, but without any teleological implications, since new approaches have never fully replaced previous trends. Ro- 
mance philology has not undergone anything akin to a homogeneous evolution, due to national traditions and linguistic barriers that have temporarily hindered or isolated new trends. Italian neo-Lachmannian philology (see 2.4), for example, was largely neglected by Anglo-American "New Philology", even though the latter was largely supported by Romanists (and Germanists), and it was only in the last quarter of the twentieth century that neo-Lachmannian philology started to become widespread in Spanish philology.

\subsubsection{Gaston Paris and the application of textual criticism to Romance literature}

Romance philology established itself as an autonomous discipline very slowly from ca. 1830, first in Germany, where its development accelerated from ca. 1860 onwards. In the beginning, chairs of modern philology (comprising Romance and Germanic philology) were created as distinct from traditional chairs of classical philology. In the last decades of the nineteenth century, Romance philology began to differentiate itself from Germanic philology at the university level.

German influence on Gaston Paris (1839-1903), who was educated in Bonn and in Göttingen, was decisive when, in 1872, he published his edition of the Vie de Saint Alexis, which is considered to be the first application of textual criticism to any Romance text (see 2.3). Paul Meyer (1840-1917), who together with Paris promoted textual criticism, noted that, in his Saint Alexis, Paris was influenced by Karl Bartsch's edition of the Nibelungenlied (P. Meyer 1911, 632). Before this, textual criticism had actually been applied to a Romance text - in Gustav Gröber's dissertation on the manuscript tradition of Fierabras (1869) - but not to the extent of producing an edition.

Paris's Saint Alexis is distinguished by its methodological aspects and description of innovative concepts. In the introduction, one finds the seeds of many key concepts that would continue to be discussed or refined thereafter. Paris's goal was clear: he wanted to break with previous editing methods that either adhered to a codex optimus or that presented a composite text combining the readings of several manuscripts according to the taste and skill of the editor. Paris was conscious of his innovative work: "Les principes de la critique des textes n'ont guère été appliqués jusqu'à présent à l'ancienne littérature française, et particulièrement à la poésie épique" (Paris and Pannier 1872, 7) [The principles of textual criticism have hitherto hardly been applied to ancient French literature, especially not to epic poetry].

He wanted to impose a rigorous editing method which, through a reasoned comparison of manuscripts, would eliminate the subjectivity of the editor. Paris refused to accept that the scientific standards of the edition of a Romance text should be inferior than those of a text from antiquity, since the "exigences [de la critique], on ne saurait trop le dire, sont absolument les mêmes pour les productions du moyen-âge que pour celles de l'antiquité” (Paris and Pannier 1872, 7) [critical exi- 
gencies, it cannot be repeated often enough, are absolutely the same for the products of the Middle Ages as for Antiquity].

He was fully aware, however, that the conditions of transmission of these texts differed greatly from one another. In particular, he highlighted that mediaeval texts were subject to more significant alterations, due both to the actions of "innovaters" ("renouveleurs") and to the degradation inherent to the copying process. These ideas contain the germ of the later distinction between innovation and error. Paris did not draw any methodological conclusions from the specificity of mediaeval vernacular traditions, apart from the fundamental distinction between the analysis of readings ("critique des leçons") and analysis of forms ("critique des formes"). Forms, themselves highly unstable, are continuously "renewed" in the course of the copying process. This variation renders the genealogical method ineffective for the analysis of forms.

For Paris, these renewals could only damage the text. He kept to the idea that textual traditions were subject to progressive "degeneration": "l'éloignement de l'original conduit toujours à une version inférieure, car moins originale justement" [moving away from the original always leads to an inferior version, precisely because it is less original]. The aim of his edition was therefore to print a text that was as close as possible to the original:

La critique des textes a pour but de retrouver, autant que possible, la forme que l'ouvrage auquel elle s'applique avait en sortant des mains de l'auteur. Ce but, elle ne l'atteint jamais complètement: elle s'en rapproche plus ou moins suivant que les conditions où elle s'exerce sont plus ou moins favorables. (Paris and Pannier 1872, 8)

[Textual criticism's goal is to reconstruct as far as possible the form the work under study had when it left the author's hands. It can never reach this goal completely; it approaches it more or less closely depending on whether its working conditions are more or less favourable.]

From the outset, Paris excluded the possibility of recovering the original in all respects and considered the result he obtained as something to be perfected and, when necessary, questioned.

One of Paris's major contributions was to apply the analysis of common errors and innovations as a basis for establishing the readings of a text:

la critique des textes, ou du moins l'une de ses parties les plus essentielles, repose en effet sur cette idée que des scribes différents, copiant un même texte, ne font pas les mêmes fautes; pour les œuvres du moyen-âge qui ont subi des renouvellements, il faut compléter cette formule par celle-ci: des 'renouveleurs' différents, travaillant sur un même poème, ne font pas les mêmes modifications. (Paris and Pannier 1872, 10)

[textual criticism, or at least one of its most essential parts, rests in reality on the idea that different scribes copying the same text do not commit the same mistakes. For mediaeval works which have been subjected to innovations, this formula has to be extended by the following one: different innovators working on the same text do not make the same modifications.] 


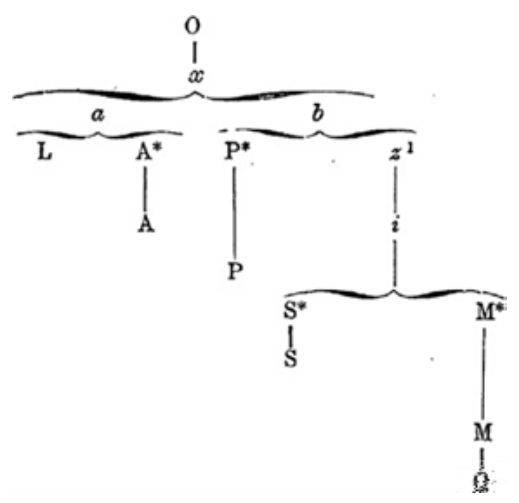

Fig. 7.3-1: Gaston Paris's stemma of the manuscripts containing the Vie de Saint Alexis (Paris and Pannier 1872, 27). Source: Gallica, Bibliothèque nationale de France, gallica.bnf.fr/ark:/12148/bpt6k33044x/f43.item). Image: CC-BY-NC.

Paris thus promoted the common-errors method, which was not an invention of Lachmann, but was instead formulated in Romanist circles (see also Gröber 1869). He went on to distinguish between classical philology, which can rely solely on common errors, and mediaeval philology, which must also take common innovations into account.

\subsubsection{Joseph Bédier: The solution of the "good manuscript"}

The efforts of Gaston Paris and Paul Meyer to introduce textual criticism in France were effective. At the same time, German scholars continued their work of publishing Romance texts by applying the stemmatic method. Among their great achievements, one should mention the edition of Bernart de Vantadorn by Carl Appel (1915) and that of Chrétien de Troyes by Wendelin Förster, completed by Alfons Hilka (Foerster and Hilka 1884-1932). On both sides of the Rhine, reconstructive editions appeared, which were based on the comparison of witnesses and on their genealogical classification.

This method gradually became established until Joseph Bédier, a former pupil of Gaston Paris, became aware of its limitations and recommended it be abandoned for the establishment of the text. A debate took shape around Bédier's edition of Jean Renart's Lai de l'ombre. In 1890, Bédier published a first edition which was consistent with Paris's teaching. However, Bédier's examination of the tradition led to a bifid stemma, which Paris contested in a review: "il résulte de ces remarques que bien probablement le Lai de l'Ombre nous est conservé non par deux, mais par trois familles, $y, v, E$, et que par conséquent l'original commun se reconstitue, à coup sûr, par l'accord de $y$ ou de $v$ ensemble ou avec E' (Paris 1890, 611) [it follows from these remarks that it is rather probable the Lai de l'ombre is extant not in two 
but in three families, $y, v, E$, and that therefore the common original is reconstructed with certainty by the agreement of $y$ and $v$ with each other or with $E$ ].

Questioning the stemma undermined the logic leading to the establishment of the text, especially since Paris had already pointed out in his Saint Alexis the methodological implications of a stemma with two vs three branches.

Bédier resumed his work and, in 1913, republished the Lai de l'ombre following a single manuscript, which he had chosen as the "base" of his edition. He thus abandoned the reconstruction of a textual state that was supposedly closer to the original on the basis of the whole of its manuscript tradition, and only corrected the text of his manuscript when absolutely necessary. After a debate with Quentin, who proposed reviewing the principles of recensio by first rejecting the notion of the common mistake (Quentin 1926), Bédier (1928) provided a long argumentation in support of his theory. He noted the significant fact that the stemmata of editions are almost always bifid (in seventy-eight out of eighty cases he examined; for the term, see 4.1.4 above). In addition, several competing stemmata could, in many cases, be offered for the same text. The application of the stemmatic method is therefore problematic, since, depending on the stemma one selects, one ends up with a different critical text; in the case of a bifid stemma, the editor's choice is decisive, leading to a discordant collaboration between the editor and the mediaeval author. Finally, Bédier recommended

\footnotetext{
un extrême 'conservatisme', un extrême vouloir, porté, jusqu'au parti pris, d'ouvrir aux scribes le plus large crédit et de ne toucher au texte d'un manuscrit que l'on imprime qu'en cas d'extrême et presque évidente nécessité: toutes les corrections conjecturales devraient être reléguées dans quelque appendice. (Bédier 1928, 356)

[an extreme "conservatism", an extreme wish carried out, to the point of partisanism, to afford the scribes as much as possible faith and not to touch a manuscript to be printed except in extreme and obviously necessary cases: all conjectural corrections should be delegated to some kind of appendix.]
}

Bédier was the first to associate the common-errors method with the name of the Berlin scholar Karl Lachmann (1793-1851). Since then, the opposition between the "method of Lachmann" and the "method of Bédier" has remained a necessary element in any introduction to the edition of texts in the field of Romance philology and beyond. These terms should, however, be considered with some circumspection, since, on the one hand, Bédier's criticism touches upon Paris's method much more than upon Lachmann's and, on the other, Bédier himself did not propose any method stricto sensu, but rather a set of editorial principles.

Abandoning the reconstructionist edition in favour of a conservative one led to the edition of a good manuscript. The choice of the latter depends on multiple criteria, sometimes contradictory, of which Bédier gave no systematic presentation. Let us simply note that the relationship to the original is only one criterion among others. This manuscript, called the "base manuscript" (Bédier 1913, xlii), is corrected only in the case of an obvious mistake, a concept that again is very vague and 
leaves the editor a considerable degree of latitude. The aim of such an edition is to present, as far as possible, a text that is as close as possible to what had been read by the mediaeval reader - in other words, a text that was used ("texte usagé"), rather than a hypothetical reconstruction. Bédier did not condemn recensio, since the stemma can be useful for the choice of the base manuscript and for discussing the probability that a reading is authentic or not. On the other hand, he contested the use of the stemma for the establishment of the text, because at this stage of the edition, especially in the case of a bifid tradition, the stemmatic method, far from producing an objective and firm result, leads to the construction of a largely subjective text that was never read as it is.

Bédier's "method" prevailed in France, to some extent in Belgium, in Great Britain, and the United States. In France, it continues to be applied, but with varying degrees of editorial interventionism. In the introductions to editions, one observes a tendency towards the declaration of principles, especially about faithfulness to the base manuscript, which are far from corresponding to the actual practices of the editors.

The interwar period brought some improvements to Bédier's principles. In order to regulate the editor's interventions in the edited manuscript, Eugene Vinaver (1939) proposed that a dubious reading cannot be considered erroneous if it is not possible to explain the origin of the error with a reasonable degree of probability. This approach leads the editor to rely naturally on recensio, since the analysis of variants often sheds light on the aetiology of mistakes. However, Vinaver takes this a bit too far, as some obvious mistakes remain inexplicable, especially in the absence of their immediate model.

At the same time, a shared desire emerged to find a middle ground between Bédier's conservatism and "Lachmannian" interventionism. Alexandre Micha (1939) proposed a compromise solution that consists of choosing a good manuscript which is then "controlled" using a suitable representative of each of the families of manuscripts discovered through the analysis of the tradition. At the theoretical level, this solution does not hold, because the degree of intervention by the editor is not specified: between the correction of an obvious error and the wish to get closer to the original, the editor has a very wide margin of freedom, in which personal taste and subjectivity may play a large role. Consequently, the edition delivers neither the text of a specific manuscript nor the most authentic readings. While the method of "control manuscripts", which experienced relatively large success in France, does not deserve to be applied generally, it offers an acceptable pragmatic solution for certain texts such as long romances transmitted by a large tradition, as has been shown by the edition of the Tristan en prose directed by Philippe Ménard (1987-1997).

\subsubsection{Neo-Lachmannism: Refining and adapting Textkritik}

While Bédier rejected the use of the genealogy of manuscripts for establishing the text, others sought to amend the genealogical method (see also 2.4). This was the 
case with Henry Quentin, who proposed a new computational method which did not rely on the subjective concept of common errors to classify manuscripts (1926). His method, reviewed by Jacques Froger (1968), inspired stemmatologists, but, although it was applied to the Lai de l'ombre, it had little effect on the work of Romanist scholars.

In Italy, Romanists were at the forefront of introducing textual criticism of German and French origin. In spite of the edition of Arnaut Daniel by Ugo Angelo Canello (1883), which relied on conjunctive and separative errors, and the methodological openness of Pio Rajna (1847-1930), it was not until the edition of Dante's Vita Nuova by Michele Barbi in 1907 that one saw the first rigorous application of the commonerrors method to an Italian text endowed with a rich tradition (Barbi 1907).

The systematic treatise on textual criticism by Paul Maas (1927) was decisive in the development of Italian n e o- L a ch man n is m (see 2.4). Outlined in a review of Maas's booklet (Pasquali 1929), the reflections of the Hellenist and Latinist Giorgio Pasquali (1885-1952) later resulted in a masterwork, Storia della tradizione e critica del testo (1934). The title is methodologically indicative: the history of textual traditions and their individual specificities must be taken into account in the application of the stemmatic method. Pasquali therefore encouraged a more flexible practice adapted to each tradition, emphasising especially the difficulties of stemmatic criticism by developing concepts such as horizontal tradition, contamination, authorial variant, and open recension.

The influence of Pasquali is reflected in the now-classic essay by Barbi, La nuova filologia e l'edizione dei nostri scrittori da Dante a Manzoni (1938). A critical and constructive revision of the Lachmannian method, adapted to the tradition of vernacular, mediaeval, and modern texts, was thereby encouraged. In line with Pasquali, the "nuova filologia" aimed at combining stemmatic rigour and attention to the textual tradition by considering witnesses individually as the products of a specific cultural context rather than as mere reservoirs of variants. Gianfranco Contini (1912-1990) pursued the renewal of editorial methods advanced by this school, now known as neo-Lachmannism (Contini 1986). Contini emphasised in particular the limits of a mechanical application of the stemma and insisted that the status of the critical edition cannot be presented as definitive but always remains a working hypothesis. This last point is a clever answer to Bédier's scepticism. Contini deepened, reformulated, and applied some concepts already used by Pasquali to Romance texts. He also proposed other concepts, such as diffraction (the process by which a lectio difficilior is modified by substitutions that differ from one copyist to another, resulting in a diffuse scattering of variants) or the diachrony of the text, which one can only perceive through a genealogical approach. The next generation further pursued these theoretical reflections, developing, for example, the concept of the text as a diasystem (Segre 1979) or the idea of active or quiescent traditions (Vàrvaro 1970; see, in more detail, 2.4.3 above).

The attention given to the history of textual traditions by the neo-Lachmannians encouraged them to claim a partial autonomy from classical philology: the temporal 
and cultural gap between original text and copy differs between antique and mediaeval texts, as does the authority they enjoyed; and classical languages display a degree of standardisation unknown to mediaeval vernacular languages. It is important that Romance philologists take these differences into consideration.

This moderate Lachmannism, which has become a trademark of the Italian school, spread particularly in Hispanic philology in the last quarter of the twentieth century, following the publication by Giorgio Chiarini of the Libro de buen amor (1964) and the teachings of two neo-Lachmannian scholars, Alberto Blecua (1983) in Barcelona and Germán Orduna (2000) in Buenos Aires. For linguistic reasons, the intense methodological reflection of the neo-Lachmannians did not find the audience it deserved: the "New Philology" (see 2.3.7) ignored their work, and the French tradition, largely atheoretical after Bédier, did not know it well. Efforts, with a hint of proselytism, have been made in recent years to win over French- (e.g. L. Leonardi 2003), English- (e.g. Trovato 2017), and Portuguese-speaking (Spaggiari and Perugi 2004) audiences.

\subsubsection{Textual scholarship emancipated from author and original}

Getting closer to the lost original was the goal of Gaston Paris, and it is still shared by the neo-Lachmannians, even though their approach is more cautious, adapting itself to each textual tradition. So-called Bédierist editions have a more ambiguous position. According to Bédier, the chosen good manuscript did not need to be the closest to the original. But one of his most influential disciples, Félix Lecoy (1978), spoke of the possibility of evaluating the authenticity of the readings printed in the apparatus. In fact, the criterion of proximity to the original often prevails. "Bédierist" editions are thus de facto oriented towards the mediaeval author, just like their Lachmannian cousins. Both are based, at least initially, on a conception of the text as an individual creation.

A third editorial trend has developed, which does not operate in terms of originals. Its origins are manifold and in some cases completely independent in their development: Spanish neo-traditionalism, advanced by Menéndez Pidal and the literary criticism of lyric texts, considers mediaeval texts not as fixed individual creations but as the result of a collective enterprise, always capable of evolving. The logical consequence of this, in editorial terms, is the publication of each manuscript or a representative of each family or group of manuscripts. Castilian neo-traditionalism anticipated the concept of mouvance formulated by Paul Zumthor (1972), and even that of variance promoted by Bernard Cerquiglini $(1989,111)$ and the "New Philology”. It also joins the sociology of texts put forth by McGann, who, with respect to the modern period, postulates that "literary works are fundamentally social rather than personal or psychological products” (1983, 43). Finally, Avalle, at first an orthodox neo-Lachmannian, concludes that there is a double truth: that of the 
authoritative text sought in the reconstructionist edition, and that of the document. For Avalle, "Bédier's method makes sense only if it is applied on the basis of the mediaeval book and not of the original" (1972b, 554). The correction of the manuscripts by Bédier's followers does not make sense from this perspective. Avalle in turn emphasises the complexity of the manuscript, a crystallisation of several actors whose exact role is difficult to determine. In order to reach the truth of the document, it is necessary to multiply the editions of manuscripts. Avalle thus echoes the concerns of material philology.

The "New Philology", which places the manuscript (and no longer the text) at the heart of its thinking, appeared in the United States in the late 1980s and early 1990s, before its influence expanded; it first developed in the milieu of mediaevalists. In many respects, it converged with the views of Menéndez Pidal or Avalle, although it was independent of them. Cerquiglini's essay, Eloge de la variante: Histoire critique de la philologie (1989), which was quickly translated into English, contributed to its growth. In editorial terms, the "New Philology" could be considered as a radicalised form of Bédierism, which explains its lack of success in Italy. On the other hand, Spanish philologists familiar with Menéndez Pidal's work welcomed it warmly, especially following the publication of John Dagenais's The Ethics of Reading in Manuscript Culture: Glossing the Libro de Buen Amor (1994).

The stemmatic method, which assumes an orientated and orderly ranking of witnesses and an evaluation of readings (possibly authentic readings vs erroneous readings), has been rejected, sometimes violently, by the "New Philology", which adopts an undirected point of view. The latter has enjoyed support from technological developments, in particular in photography and computer science. The digitisation of manuscripts was the most radical proposal that the "realistic" "New Philologists" could make in order to distance themselves from the old "idealist" philology. As for computer science, thanks to "multi-fenestration" (Cerquiglini 1989) and hypertext, it is possible to simultaneously and conveniently display several transcriptions or reproductions of manuscripts of the same work.

The concurrent development of new theories of the text, of which the "New Philology" is an emanation, and progress in computer science led to the realisation of documentary digital editions which do not rely on a stemma, often also in the choice of the manuscripts to be transcribed. In terms of electronic publishing, a focus on the document largely dominates, and critical editions are being abandoned for the sake of digital archives or libraries, as in the project of the Roman de la rose led by Nichols (2014).

The importance of Romance philology in editorial practice is due to the now age-old debate initiated by Joseph Bédier. In each of the editorial approaches that have ensued, the fate of the stemmatic method differs: whereas neo-Lachmannians still utilise it for the establishment of the text, the Bédierist tradition stops using it after the initial recensio, which is useful both for choosing the base manuscript and analysing variants. The "New Philology" is more radical, because it envisions the manuscript as both its point of departure and its point of arrival. 
One of the last articles by Cesare Segre, a great figure of Italian neo-Lachmannism, celebrates the end of the war between Lachmann and Bédier (Segre 2016). Segre admits the plurality of approaches: it is legitimate to look for the authentic reading, but also to examine as such the reading of a given manuscript, regardless of the genealogy of the witnesses. Digital technology today makes it possible to combine the two approaches within the same project (for examples, see 6.3.3). At a time when digital documentary editions and archives dominate, it is possible to imagine that integral transcriptions of the witnesses of a work will lead to a reelaboration of stemmata thanks to the progress of stemmatology. For the moment, the application of stemmatology to mediaeval Romance texts is still at an early stage because it requires not only the encoding of all the witnesses but also their lemmatisation. Experiments are sporadically attempted, but a large-scale application has not yet been envisioned. In addition to the Amsterdam school initiated by Anthonij Dees (see van Reenen and Schøsler 2000, 31-32, 53-54, for a first assessment; see also de Visser-van Terwisga 1999, 200-211), there have been a few other, relatively isolated, initiatives (Trovato 2017, 179-227; Camps and Cafiero 2014). Stemmatology is dependent on progress in the automated lemmatisation of highly variable language states, like Old French, even though the rise of machine learning opens up new possibilities. In the meantime, the stemma can already serve as a gateway to the textual and codicological data of digital libraries. In the field of Romance philology, much of the work in this respect still remains to be undertaken.

\section{Acknowledgement}

The text was translated from the French by Caroline Macé and Laura Endress.

\section{Further reading}

An overview of philological practices in Europe can be found in Duval (2006). Montanari (2003) provides an Italian translation of Maas (1927) with a commentary situating the importance of Maas's method in Italian philology. Stussi (2006) is influential on the methodology of textual criticism in Romance philology. Readers interested in knowing more about the practice of philology in the study of mediaeval Spanish could refer to Altschul (2015). 


\subsection{Mediaeval German}

Ralf Plate

Scarcely less extensive than the variation in the mediaeval German textual tradition of the manuscript era is the multiplicity of types of editions which, from their beginnings in the early nineteenth century, have been grappling with these texts. Between the extremes of diplomatic documentation and reconstruction by means of arbitrary conjectural criticism lies the domain of stemmatics. In this context, there is, right from the start, a wide range of goals, methods, and forms of realisation that have survived even the "iconoclasm of the "New Philology" (Heinzle 2003, 1; "der Bildersturm der 'New Philology”'). The following short historical survey can only outline, by means of examples, the main stages and aspects, concentrating on the way in which variation is handled and the role that is assigned, or alternatively denied, to stemmatics. It focuses on the stemmatics of the courtly epic around $\mathrm{AD} 1200$, since it is here that the great controversies have flared up, right up to the present day.

\subsubsection{Lachmann's recensio of the courtly epic ca. AD 1200}

Lachmann, as is well known, never provided a stemma in his editions and was altogether sparing with the details he provided of the manuscript relationships this applies not only to Lachmann the classical philologist (Timpanaro 2005) but also to Lachmann the Germanist (Sparnaay 1948; Ganz 1968; Fiesoli 2000, 269-358). In the case of Middle High German poetry, the reason for this was not so much Lachmann's oracular style (Timpanaro 2005, 96, 117) but the result of his recensio. It was always directed at the oldest attainable text in the manuscript tradition; Lachmann was interested in the history of a textual tradition not in its own right but only insofar as it was necessary for the establishment of the critical text, just as in the case of classical texts (Timpanaro 2005, 72). Three texts with an extensive manuscript tradition may serve as examples.

In the case of the Nibelungenlied (1st ed. 1826, notes (with full variants) 1836, 2nd ed. 1841), the main problem with any assessment of the manuscript tradition is the transition from oral tradition to the book epic and its written tradition, which took place in various stages at the beginning of the thirteenth century (for an overview of the subject from a modern perspective, see Heinzle 2013, 998-1006). The complex problems cannot be explored here in detail. According to Lachmann's recensio, the oldest stage of the text is represented by only one manuscript $(A)$; all others go back to an adaptation, ${ }^{*} B$, which appears in a subgroup in a further comprehensive adaptation, ${ }^{*} C$. For the establishment of the text of ${ }^{*} A$, the textual tradition of ${ }^{*} B$ and ${ }^{*} C$ is - because of their character as adaptations - only of limited value, that is to say, significant only when it allows the reading of $A$ to be supported 
or, in the case of deviations from it, allows corruptions of the archetype ${ }^{*} A$ to be established: "every word that is not in $A$ is of no greater importance than a conjecture. All other manuscripts are teeming with obvious conjectures" (Lachmann 1841, $\mathrm{x}$; "jedes wort das nicht in A steht, [hat] keine größere beglaubigung als eine conjectur. alle anderen handschriften wimmeln von augenscheinlichen conjecturen”). By this, Lachmann meant that emendations had been made to passages in the older text, ${ }^{*} A$, "where readers and scribes of the thirteenth century took offence" (Lachmann 1841, x; "woran leser und schreiber des dreizehnten jahrhunderts anstoß nahmen”). Lachmann's edition offers the reconstructed text of ${ }^{*} A$. The apparatus contains the variant readings of adaptation ${ }^{\star} B$, as far as they could be reconstructed; otherwise, it gives the readings of individual manuscripts which could help establish the text of ${ }^{*} B$. Whereas ${ }^{*} A$ is transmitted directly in only one manuscript, Lachmann had at his disposal eleven manuscripts for ${ }^{\star} B$ and six for ${ }^{*} C$ (Lachmann 1841, $\mathrm{x})$. Since Lachmann attempted to reconstruct the places where adaptation ${ }^{\star} B$ varied from ${ }^{*} A$, one might expect him to have provided details of the manuscript relationships in this group. However, we find only the conclusion that the manuscripts of ${ }^{*} B$ in part diverge substantially and then do not permit the reconstruction of ${ }^{*} B$. Lachmann's edition offers no more specific explanation of his findings regarding the manuscript tradition, probably because he assumed this to be obvious. As we learn from Lachmann's 1817 review of von der Hagen's edition of the Nibelungenlied, based on manuscript $B$ (1816), he posited in the case of ${ }^{*} B$ (and, by analogy, probably also of ${ }^{*} C$ ) an unstable archetype: at the beginning of the manuscript tradition of the adaptation ${ }^{*} B$, there existed a manuscript with the text of ${ }^{\star} A$, in which the ${ }^{*} B$ adapter had noted his changes and additions in the margin; in part the copies of ${ }^{*} B$ took over the changes and additions, in part they ignored them, and in part they introduced their own (Lachmann 1876, 1:87).

The basic picture of the manuscript tradition in the case of Iwein presents itself to Lachmann in a scarcely more favourable light (the establishment of the text and the variants in this edition are by Lachmann; see Lutz-Hensel 1975, 337-342). He states:

The oldest manuscript, $A$, does not show a closer relationship to any of the others: changes that are clearly intentional are never shared with another manuscript. Thus, the critical rule of following this manuscript where it is not found to be in isolation established itself automatically, since it is nearest to the original source of the manuscript tradition. Each of the manuscripts used [...] has, through agreement with $A$, contributed something to our decisions. (Benecke and Lachmann 1877 [= 2nd ed. 1843], 362)

(Die älteste handschrift A ist mit keiner der andern näher verwandt: veränderungen die erkennbar absichtlich sind, hat sie niemahls gemein mit einer andern. so ergab sich von selbst die kritische regel, ihr, da sie der ersten quelle der überlieferung am nächsten ist, zu folgen, wo sie nicht allein steht. jede der gebrauchten handschriften [...] hat durch übereinstimmung mit A etwas zur entscheidung beigetragen.)

In his introductory remarks on the variants, Lachmann provides no further information about the genealogy of the manuscript tradition (he did, however, mention some 
of his findings in his discussion of the variants; see Ganz 1968, 22-23, with a tentative stemma). The reason for this may be similar to that in the case of Nibelungenlied ${ }^{*} B$, for, as Lachmann already knew (Ganz 1968, 23) and Henrici's study later showed (see 7.4.3), the manuscript tradition of Iwein eludes genealogical description.

Concerning Wolfram von Eschenbach’s Parzival, Lachmann in 1833 states: "The numerous manuscripts of Parzival fall [...] into two classes, which consistently display a different text” (in Schirok 1999, xiv; "die zahlreichen handschriften des Parzivals [...] zerfallen [...] in zwei klassen, die durchgängig einen verschiedenen text haben"), so that "in most cases, the reading of one class is of equal value to that of the other" (Schirok 1999, xvii; "in den allermeisten fällen [ist] die lesart der einen klasse mit der andern von gleichem werth"). Lachmann consistently compared the principal manuscripts of both classes ( $D$ and $G$ ); he compared others only in the case of disagreement between these two manuscripts. The constitution of the text rests largely on $D$ - "admittedly a weakness of my text" (in Schirok 1999, xvii; "freilich eine schwäche meines textes") -, and the equally acceptable readings (presumptive variants) of ${ }^{*} G$ are emphasised, where appropriate, in the apparatus by placing the sign "=" before them. Lachmann gives no information about the internal division of both classes, most noticeably in the case of the considerably larger $G$ class; indeed, he specifically rejects the suggestion: "to what end should one pursue the investigation in the minutest detail" ("wozu sollte man die untersuchung ins kleinliche führen") when the equally acceptable readings that both classes demonstrate display nothing but "negligence, arbitrariness, and a craving for improvement, without any particular skill” ("nur nachlässigkeit, willkür und verbesserungssucht ohne sonderliches geschick") - when, that is, they are innovations of the manuscript tradition, not authorial variants ("no difference going back to the poet"; in Schirok 1999, xvi; "keine von dem dichter selbst ausgehende verschiedenheit")?

According to Timpanaro, the typically "Lachmannian" procedure in works of classical philology is characterised by an aversion against the eclectic selection of variants according to internal criteria and a consequent preference for mechanical recensio (Timpanaro 2005, 88-89, 116). French philologists have understood "Lachmann's method” in this sense since Bédier (see 7.3.2), Italian philologists likewise since Timpanaro's teacher Pasquali (Trovato 2017, 70-75), and Germanists have understood it thus since Stackmann (1964; see 7.4.4 below) at the latest. As we have seen, this is at any rate not accurate with regard to Lachmann's actual procedure when editing Middle High German literature (see also Fiesoli 2000, 269-358): Lachmann's recensio led in all three cases to a preference for one manuscript as the basis for the reconstruction of the text (Nibelungenlied A, Iwein A, Parzival D); his assessment of the three manuscript traditions and his editorial goals did not permit a mechanical selection of variants by the elimination of singular readings (eliminatio lectionum singularium) using a stemma as guide. In the case of Iwein, where the possibility of using a mechanical selection procedure seemed most likely (according to Lachmann's rule, where $A$ was in agreement with any other manuscript), internal 
criteria (especially metre, grammar, and stylistics) in many cases break the rule of recensio, as the study of Lutz-Hensel $(1975,337-432)$ has demonstrated. The application of "Lachmann's method" to the Middle High German classics remained the preserve of those who opposed Lachmann's ideas and tried to refute his often acerbically and provocatively formulated findings about the textual tradition - by means of stemmatics.

\subsubsection{Karl Bartsch's recensio and stemma of the Nibelungenlied $(1865,1870)$}

The first printed graphical displays of manuscript relationships in a stemma codicum are thought to have appeared around 1830 and then to have spread rapidly in the field of classical philology (see 4.1.2). The device was even used by Lachmann's pupils during his lifetime, whereas Lachmann himself did not make use of it, even in his last editions of Latin authors (Timpanaro 2005, 96). The technique of genealogical recensio had most likely been transferred from classical philology to that of the vernacular literatures. Saint Alexis by Gaston Paris (Paris and Pannier 1872) counts as the first edition of the new type in the field of Romance studies (see 7.3). It is known that Paris was influenced by Karl Bartsch's works on the Nibelungenlied (see 7.3.1 above; Trovato 2017, 50): the Untersuchungen [Studies] (Bartsch 1865); the editio minor of 1866 (this edition, in the revised version by Helmut de Boor, is by far the most frequently used to this day, Bartsch and de Boor 1979; see 7.4.5); and the editio maior (Bartsch 1870-1880), which appeared in three volumes: 1870 (introduction and text), 1876 (variants), and 1880 (glossary). Bartsch distinguishes between two adaptations of an older text which cannot be reconstructed: ${ }^{\star} A B$ (his siglum $X$ ) und ${ }^{*} C$ (his siglum $Y$ ), where the adaptation ${ }^{*} A B$, best represented by manuscript $B$, remains closer to the lost "original", whereas ${ }^{*} C$ is more distant from it. $A$ is considered by Bartsch as an abbreviated adaptation of ${ }^{*} A B$. In the text volume of the editio maior, as also in the editio minor, $X={ }^{*} A B$ is reconstructed; the critical apparatus notes in comparison the variant readings of $Y={ }^{*} C$. Bartsch does not yet provide a complete genealogy and rules for a mechanical selection of variants based upon it, nor does he give a graphical depiction of the manuscript relationships in the Untersuchungen; only in the editio maior does he sum up his remarks about this in a simplified diagram of his findings, which he calls a "table" ("Tabelle”; Bartsch 1870-1880, 1:xviii; see fig. 7.4-1 below). But Bartsch does differentiate subgroups of the manuscripts of a version; he argues using indicative (monogenetic) common errors, which he is able to distinguish from random agreements in secondary readings (polygenetic errors), and he discerns groups of manuscripts which alternately follow one version or another, or in some other way present “mixed texts" (Bartsch 1870-1880, 1:xviii-xxix; "gemischte Texte”). 
Folgende Tabelle stellt das Verhältniss der Handschriften übersichtlich dar.

X $\quad$ Y

Originale der beiden uns erhaltenen Bearbeitungen.

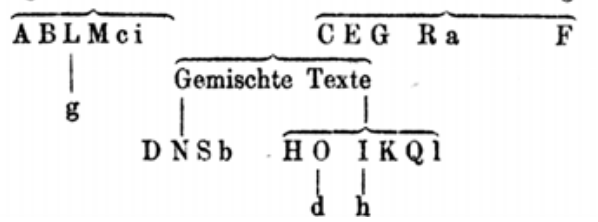

Fig. 7.4-1: Stemma for the Nibelungenlied. Source: Bartsch (1870-1880, 1:xviii).

\subsubsection{Neogrammarian genealogical reconstruction of the courtly epic between caution and mechanics (Paul and Braune, 1873-1901)}

It is perhaps no accident that the most prominent representatives of what counts today as "Lachmann's method" are two neogrammarians who were expressly opposed to the Lachmannian school, namely Hermann Paul and Wilhelm Braune. After having presented his own critical edition of the Gregorius of Hartmann von Aue in 1873 (replacing Lachmann's edition from 1838, partly due to new finds), in 1874 Paul launched, in the first volume of the neogrammarian periodical (Beiträge zur Geschichte der deutschen Sprache und Literatur), a general attack on Lachmann's text of Hartmann's Iwein in its second edition (1843), which until then had counted as "the exemplary critical edition, having had the greatest influence on the development of editorial technique as an unrivalled role model" (Sparnaay 1948, 79; "das Muster einer kritischen Ausgabe, das als unerreichtes Vorbild auf die Entwicklung der Editionstechnik den allergrößten Einfluss gehabt hat"). Paul accuses Lachmann of "arbitrariness and violence" (Paul 1874, 289; "willkür und gewalttätigkeit") in the establishment of the text. He claimed that Lachmann had failed "to employ an in-depth study of the mutual relationship of the manuscripts, which must be regarded as an essential prerequisite for the edition of a work that is contained in numerous manuscripts" (Paul 1874, 290; "eine eingehende untersuchung über das gegenseitige verhältnis des hss. anzustellen, was als notwendige vorbedingung für die herausgabe eines in zahlreichen hss. erhaltenen werkes angesehen werden muss"), and had instead evaluated the textual tradition on the basis of a system of metrical rules which totally lacked an adequate foundation but "according to which he constructed everything, leaving all other considerations aside" (289; "wonach er alles construierte mit hintansetzung jeder anderen rücksicht”). Paul's study, which is dependent almost entirely on Lachmann's critical apparatus, arrives in two steps initially "with tolerable accuracy" ("mit leidlicher bestimmtheit") at a stemma for the second, longer part of Iwein (Paul 1874, 336; see fig. 7.4-2 below). In this, nine textual witnesses are traced back over three reconstructed intermediate stages to two hyparchetypes of an archetype; the positing of one of the hyparchetypes is, 
Ich denke also, dass es gelungen ist für den von uns bezeichneten abschnitt mit leidlicher bestimmtheit das abstammungsverhältnis der hss. zu ermitteln, welches sich etwa in folgender figur darstellen würde, in der die griechischen buchstaben die nur erschlossenen mittelglieder bezeichnen:

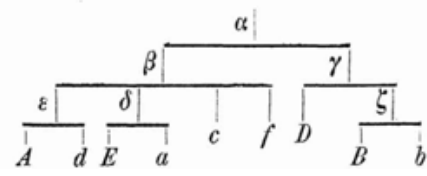

Fig. 7.4-2: Stemma for Iwein. Source: Paul (1874, 336).

however, designated as "dubious" ("zweifelhaft”), and further uncertainties are raised (Paul 1874, 337). For the first part of Iwein, an additional stemma is provided for the subsidiary sources of two of the manuscripts ( $B$ and $d$ ) which show contaminated readings (Paul 1874, 351). After formulating some critical key rules which he derives from this, Paul discusses, over more than forty pages, in detail and with reference to the constellations of the variant readings, the changes to Lachmann's text which his recensio indicates (Paul 1874, 359-401).

Paul's emphatic opposition to Lachmann's “arbitrariness” does not lead in the opposite direction, that is, towards the dogmatism of a mechanical recensio; the restricted ability of the stemma to help when evaluating variant readings in individual cases, as well as its hypothetical nature and potential for falsification, are clearly emphasised. Matters were different with Braune, whose studies of the manuscript relationships of the Nibelungenlied (1900) fill an entire year's volume of the Beiträge. Braune arrives at a stemma of the complete manuscript tradition without gaps, "right down to the individual manuscripts and fragments" (Braune 1900, 192; "bis zu den einzelnen hss. und fragmenten hinab"). Lachmann's $A$ is thereby reduced still further than with Bartsch to a secondary position, as a member of a subfamily of the hyparchetype which is best represented by $B$. The application of the stemma to the critical establishment of the text (Braune 1900, 212-215) as a rule permits the reading of the archetype to be recognised with pleasing accuracy; for the most part, the agreement of two manuscripts ( $B$ and $d$ ), which are not related and which each reproduce the text of one of the two assumed hyparchetypes $x$ and $y$ in a fairly conservative way, fully suffices for this purpose. When they stand together with a common reading, in opposition to a common reading of unrelated groups of the remaining manuscript tradition, a chance "secondary coincidence" (Braune 1900, 212; "secundäres zusammentreffen") is only seldom the case with these two manuscripts, whereas it occurs "in the majority of cases" ("in der mehrzahl der fälle”) with the others (213-214). Braune's detailed complete stemma has to be assembled from the partial stemmata which occur throughout his work (as in Brackert 1963, 174; see fig. 7.4-3 below). It represents the pinnacle of unbridled faith in genealogical reconstruction (in the field of the manuscript tradition of the courtly 


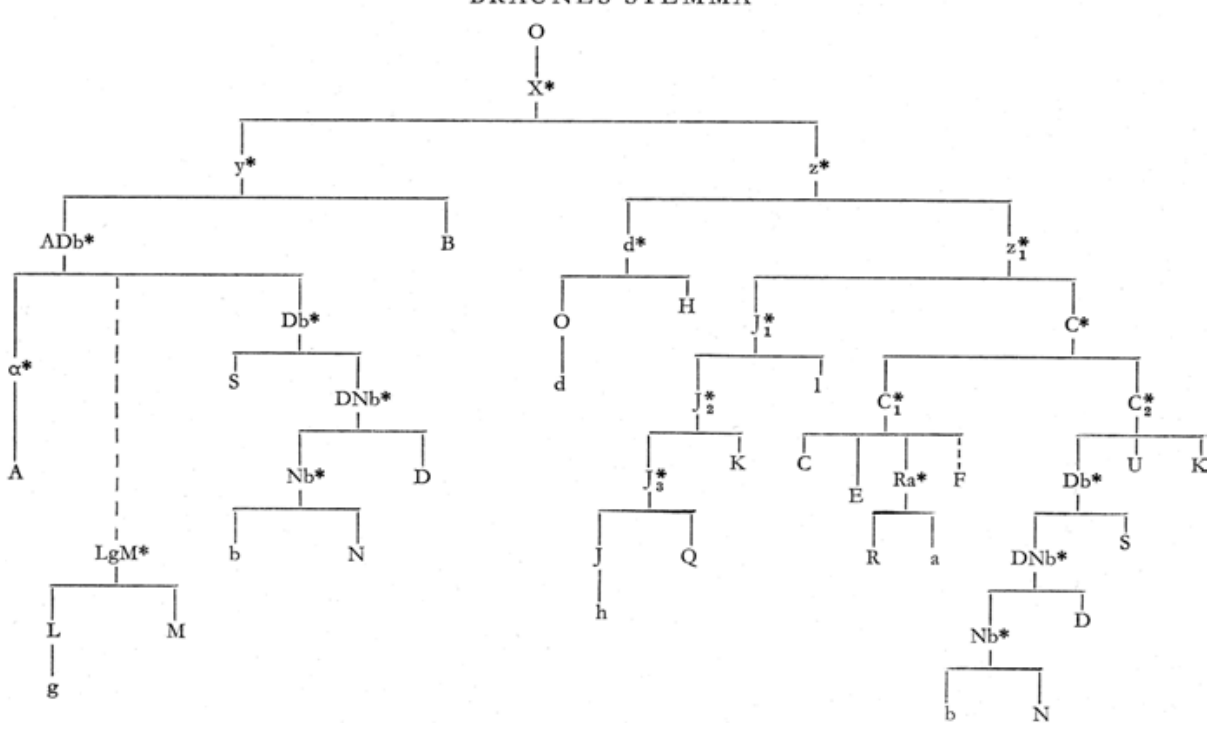

Fig. 7.4-3: Detailed complete stemma for the Nibelungenlied according to Braune (1900). Source: Brackert $(1963,174)$. (C) De Gruyter.

epic around $\mathrm{AD}$ 1200) that will then later, ironically, provoke fundamental criticism of "Lachmann's method" (see 7.4.5). Braune himself did not produce an edition, but the results of his study had an effect on the revision of the editio minor of Bartsch by Helmut de Boor (from the 10th ed., 1940, onwards; see 7.4.5 below).

However, Braune is not representative for stemmatics at the end of the century. Henrici, in his Iwein edition (text 1891, notes and variants 1893), was the first person to compare independently the entire known manuscript tradition. As a result, he rejects not only Lachmann's and Paul's recensio, but any possibility of a genealogy: contamination is rife, not only in the first part, as Paul assumed; it also occurs throughout the entire text and manuscript tradition, including $A$, even where Henrici confirms its relatively conservative unique position. Henrici considers it to be possible that there were several authorial versions, "several genuine Iweins" (Henrici 1891-1893, 2:xxxii; "mehrere echte Iweine") that are mixed together in the manuscript tradition.

Paul's handbook article on textual criticism, or more precisely, a short section in it about the determination of manuscript relationships (Paul 1901, 192-194) remains decidedly reserved about the possibilities of a genealogical recensio. He warns sternly against an unthinking mechanical approach: "the process must [...] not become a mechanical one” (Paul 1901, 193; “das Verfahren darf [...] kein mechanisches werden"). Paul stresses the need to determine genealogical relationships on the basis of "particular shared deviations from the original" (1901, 192; "besonderer gemeinsamer Abweichungen von dem Original”), that is, significant common errors/innovations, 
which indeed must "already be recognised on the basis of internal criteria" (193; "bereits auf Grund innerer Kriterien erkannt sein"). He points several times to the possibility of chance agreements in secondary readings (polygenetic errors/innovations), which can be assessed only according to probability ("to assess how much leeway may be attributed to chance is not an easy task", Paul 1901, 193; "abzuschätzen, wieviel Spielraum man dem Zufall zuweisen darf, ist keine so einfache Aufgabe”). He mentions the need to bear in mind the possibility of contamination ("the use by the same scribe of several source manuscripts", Paul 1901, 193; "Benutzung mehrerer Vorlagen durch den gleichen Schreiber”). He also determines that, all things considered, "there are enough cases where a decisive result is not reached" (Paul 1901, 193; "es Fälle genug gibt, in denen man zu einem entscheidenden Resultat nicht gelangt") - where the genealogical method, then, cannot be used. If a positive result is achieved and the method can be applied, however, the difficulties that were already encountered when the manuscript relationships were established recur in the selection of readings. Here, again, it is a case of using internal criteria and assessing the possibility of chance common secondary features; these uncertainties are multiplied when lost connecting links from manuscripts dependent on them have "to be constructed” (Paul 1901, 193; “zu konstruieren”), as Paul demonstrates with different constellations (194). Paul's reservations about the possibilities of a mechanical recensio are demonstrated by his own editions (first and foremost that of Hartmann von Aue's Gregorius; see 7.4 .5 below), and also by some of the critical editions by others in the Altdeutsche Textbibliothek series, founded by Paul and still in existence today (on the diverse programme of the series, see Kiening 2016).

A similar attitude with regard to Paul's reservations was later adopted by the Middle Latin scholar Hermann Kantorowicz in his introductory monograph to textual criticism (1921). After the appearance of Maas's account in 1927, which quickly achieved canonicity, both works, Paul (1901) as well as Kantorowicz (1921), unfortunately hardly enjoyed any further reception at all in the field of German philology.

\subsubsection{Editing post-classical and late mediaeval literature by printing "as good and as old a manuscript as possible": The Deutsche Texte des Mittelalters (1904-)}

When Joseph Bédier, in his second edition of Jean Renart's Lai de l'ombre in 1913, made a programmatic plea for the rejection of the genealogically reconstructive edition in favour of printing the "best manuscript" and accomplished this himself with an example (see 7.3.2 above), twenty-four volumes of the Deutsche Texte des Mittelalters (DTM) series of the Königlich Preußische Akademie der Wissenschaften, founded in 1904 and still in existence today, had already appeared. The DTM programme corresponded fairly exactly to Bédier's demands (or the other way round): "As good and old a manuscript as possible should consistently be reproduced” (Roethe 1904, vi; "Es soll 
durchweg eine möglichst gute und alte Handschrift wiedergegeben werden”). The programme represented "a deep incision in the methodology" (Fromm 1995, 77; "einen tiefen Einschnitt in der Methodengeschichte”) of mediaeval German literary editions, by rehabilitating the principle of the base manuscript. But, unlike in the case of Bédier, the programme was not principally directed against the genealogically reconstructive edition. That type of edition would not have been suitable anyway for some of the texts that were edited in the DTM series (because of traditions with a narrow or unique manuscript basis, or because they represented late mediaeval utilitarian prose texts). In the other cases, where it would appear to have been fundamentally possible, pragmatic considerations meant that the initial priority was instead a rapid supply of textual editions for the still largely unresearched areas of post-classical and late mediaeval literature (Roethe 1904, v; see also the assessment in Roethe 1913, 55-58). At any rate, this meant, in Roethe's opinion, “only a partial abandonment" ("nur teilweise einen Verzicht"), because the prints of the manuscripts "at the same time maintained their lasting independent value, inasmuch as they exemplify approximately the form in which the works of the Middle Ages were actually read" ("haben [...] zugleich ihren dauernden selbständigen Wert, insofern sie annähernd die Gestalt veranschaulichen, in der die Werke des Mittelalters wirklich gelesen worden sind"); in this function, they perform "services that could never be supplanted by critical editions" (Roethe 1904, vi; "Dienste, die durch kritische Ausgaben nie ersetzt werden können"). The print of a manuscript should show editorial interventions as little as possible (minor normalisations and sparing punctuation, insofar as this appeared essential for readability), and only obvious errors should be corrected. The use of corrective manuscripts was allowed as necessary; "a complete collation" ("eine vollständige Kollation"), on the other hand, "was not in accordance with the Academy's intentions” (Roethe 1904, vii; “entspräche [...] nicht den Absichten der Akademie”). This “one-manuscript rule” was often abandoned, even in the first phase of the DTM under Roethe's direction, because it would not have produced a satisfactory text, and even more often later, but it was adhered to in principle (overviews: Fromm 1995, 77-79; Stackmann 2005, 12-17). Though intended merely as a provisional solution, in some cases it has promoted the manuscript text chosen for print to become the textus receptus for all ensuing literaryhistorical research, despite the fact that its status within the manuscript tradition has never been clarified. A spectacular case in point is the world chronicle in verse of Rudolf von Ems (Ehrismann 1915 = DTM 20), a text with an extraordinarily broad transmission from the 13th through the 15th centuries (see Plate 2020).

\subsubsection{Missing prerequisites of “Lachmann's method", vote for a renewal of the eclectic critical edition (Stackmann 1964)}

Works of the classical courtly period and later texts in this tradition remained, even after the establishment of the DTM, the domain of the critical edition, partly because 
the DTM series of texts scarcely ventured into this field, and partly because when, contrary to the original plan, it did, critical editions were sometimes the result (Fromm 1995, 78-79; Stackmann 2005, 14-16), but first and foremost because people saw no reason to replace the old editions. Not until Stackmann in 1964 was their legitimacy discussed in depth, in what is today still one of the most frequently quoted essays about methods and problems of editing medieval German texts, albeit cited selectively by those who are opposed to critical editions in principle. The essay is dedicated to the question of the appropriate contemporary continuation of the critical edition. Stackmann seeks to connect with the methodological discussion that Bédier had initiated, principally concerning Romance and classical philology (Pasquali, Timpanaro), and takes from this discussion the picture of the "Lachmannian method" as that of mechanical stemmatic reconstruction as it was described by Maas (1927, 4th ed. 1960); he does not cite Paul (1901) or Kantorowicz (1921). Stackmann confronts this with a reference to its unquestioned prerequisites which, however, he maintains, are in reality rarely present. He states that the method rests on a "theory about a very special case" which is present only when the following criteria are satisfied (Stackmann 1964, 246-247): (i) the source of the manuscript tradition must be a single, clear-cut archetype; (ii) the manuscript tradition must follow an exclusively vertical path without contamination; (iii) the manuscript relationships must be recognisable on the basis of properly detected errors; and (iv) the manuscript tradition must be exclusively the work of copyists, and there must not be any unpredictable jumps between source and copy.

For confirmation that these conditions - at any rate in the tradition of the courtly epic - are rarely to be found, Stackmann could have appealed to Lachmann himself, as we have seen (7.4.1). In fact, Stackmann does not argue in terms of individual examples of unsuccessful genealogically reconstructive editions, so it remains unclear at what editorial practice the objection to the "Lachmannian method" is levelled; it is likely that Braune's stemma for the Nibelungenlied (see 7.4.3) lies behind it, as the spectacular dissertation by Brackert (co-supervised by Stackmann and published in 1963) had shortly before shown it to be fundamentally lacking and inadequate in all its details.

The conclusion that a genealogical recensio could not feasibly be employed presented various possibilities for editorial practice: either, with Bédier (and an eye to the DTM series) to give up resignedly the reconstruction of a text that is better than the manuscript tradition, that is, restricting editing to a cleaned-up print of the "best manuscript" - or alternatively deciding in favour of an eclectic critical edition (in the positive sense of the term), that is to say, one that is based on a profound knowledge of the manuscript tradition and critically reflective in method. Stackmann (1964) votes decisively in favour of the second option; the greater part of his essay is devoted to the fundamentals of an appropriately modern eclectic critical edition. The main points are orientation towards a base manuscript where linguistic form is concerned; acceptance of recurring variants (relatively small variations in linguistic 
usage that are insignificant for the sense of the text); elimination of obvious errors; in the case of competing variants, application of the criterion of lectio difficilior; in the case of equally acceptable variants, clear indication of the variants that do not appear in the reconstructed text by appropriate typographical means; and avoidance, as far as possible, of conjectural criticism, about which the most severe misgivings are voiced (Stackmann 1964, 256-265).

The eclectic critical type of edition favoured by Stackmann continues to be cultivated in the field of classical epics up until the present day, albeit with significantly decreasing popularity. Prominent examples of various kinds are Wolff's revision of Benecke and Lachmann's Iwein edition (1968), Brackert's edition of the Nibelungenlied (1970-1971), de Boor's revision of Bartsch's editio minor of the Nibelungenlied (most recently, 21st ed. 1979), and Schröder's edition of Wolfram von Eschenbach's Willehalm (1978). Werner Schröder has been a continually present figure in the recent history of mediaeval German editions, also as a reviewer, and has supported the position of the eclectic critical edition in some sharp exchanges; a series of reviews, which are worth reading, and review-essays from the 1990s, are reprinted in the anthology Schröder (1999). In addition, the formulation of decisive opposition to the now-common editorial resignation of Grubmüller (1993) must be mentioned and - as an example of further revisions of older editions in the Altdeutsche Textbibliothek - Wachinger's adaptation of Paul's editio minor (1st ed. 1882) of Hartmann von Aue's Gregorius (most recently, 15th ed. 2004). Wachinger, who was also the head editor of the series for many years, notes, with regard to Gregorius,

that the combinations of manuscript readings that contradict the stemma, whether they occurred through mixing, through independent, but parallel, alterations, or through correct scribal conjectures, are so numerous and so weighty that the stemma on no account can be regarded as a secure basis for individual text-critical decisions. (Wachinger 2004, xix)

(daß die dem Stemma widersprechenden Lesartenkombinationen, mögen sie nun durch Kreuzung, durch unabhängige aber gleichgerichtete Veränderung oder durch richtige Schreiberkonjekturen zustandegekommen sein, so zahlreich und so gewichtig sind, daß das Stemma keinesfalls als gesicherte Grundlage textkritischer Einzelentscheidungen angesehen werden darf.)

Wachinger then evaluates the advantages and disadvantages resulting from both the alternatives faced by the editor in view of these findings: to edit from a base manuscript or to opt for an eclectic critical edition. He concludes: "Both procedures, when performed competently, seem to me equally legitimate” (Wachinger 2004, xx; "Beide Verfahren, kompetent durchgeführt, scheinen mir gleich legitim"). Wachinger himself stays with Paul's cautious, eclectic critical procedure.

\subsubsection{The history of textual tradition and the edition of late mediaeval utilitarian prose in the Texte und Textgeschichte series (1980-)}

The genealogically reconstructive edition, which has been banished since Stackmann's article in 1964 from the field of the courtly epic (in which, however, it was 
hardly ever realised in its pure form), found its most comprehensive application in a Würzburg research group, begun in 1973, and its research into the history of the textual tradition of prose works (according to the title of the group's volume on methodology, Textgeschichtliche Prosaforschung; Ruh 1985). Its results are published in the series Texte und Textgeschichte, in which fifty-six volumes of studies and editions have appeared since 1980, including extensive multivolume editions of texts with extraordinarily broad and variable manuscript traditions in the late Middle Ages and beyond. An example can perhaps best illustrate the methodology and results achieved. The manuscript tradition of the Rechtssumme (a summa of ecclesiastical law and Christian life) by an otherwise unknown Dominican Friar Berthold, probably from the second half of the fourteenth century, begins at the end of the fourteenth century and is extant in approximately eighty-nine manuscripts and twelve early prints. The edition (Steer and Hamm 1987-2006) is based on a complete recensio of the entire manuscript and print tradition and a computerised collation. It leads to the assumption of four main versions (three redactions $A, B, C$ and an adaptation of the third redaction, $C y$ ), which have taken shape in the manuscript tradition and in turn appear in numerous post-redactional stages of the text. These stages are genealogically reconstructed in the traditional way (using significant common errors/innovations), as lost links between the versions and the surviving textual witnesses. The complete stemma is shown on a five-page pull-out (vol. 1, preceding p. 219^); only a few textual witnesses are to be classified as pre-redactional (preceding the redactions $B$ and $C$ ). The edition does not aim at the archetype of an authorial text that lies at the heart of the versions, but at the four versions themselves. They are, admittedly, not directly preserved in the manuscripts, but are reconstructed from the post-redactional stages of the text (Steer 1985, 48-49); the edition offers the texts of the reconstructed versions synoptically on double pages in four columns, and the four apparatuses document the variant readings of the versions' textual traditions.

\subsubsection{Stemmatics of equivalent parallel versions of the courtly epic (Bumke 1996): New aporias, digital perspectives}

After Stackmann's article in 1964, there appeared to be, for editions of courtly epics, only two alternatives: the base manuscript or the eclectic critical method. In 1996, in a surprising turnaround, Bumke seemed to rehabilitate reconstructive stemmatics in this area - albeit under completely different conditions. Bumke draws the conclusion, from the critical study of the manuscript tradition since Lachmann, that the courtly epics of the period around AD 1200 existed from the very beginning in (critically) equivalent parallel versions that can neither have arisen from each other as adaptations nor are capable of being traced back to a fixed authorial text. He considers that the manuscript tradition, at least approximately for the first half of the 
thirteenth century, is fundamentally unstable. Not until the increase in vernacular literacy towards the end of the century did it stabilise and thus achieve the quality that makes it accessible to the genealogically reconstructive method.

Instead of the genealogy of the tradition of the authorial text, therefore, there appears, in Bumke's case, the genealogy of the tradition of the various versions. However, in this way, the authorial text creeps in again through the back door: this occurs where the manuscript tradition of a version diverges and comparison with the other versions tips the balance in favour of a particular reading (Bumke 1996, 605-608), for in this way it is acknowledged that a common source for the versions can be reconstructed (see Schröder 1998, 295-296). Admittedly, Bumke did not draw this conclusion in his editorial work. Instead, in the edition of the four versions of the Nibelungenklage that he had ascertained, he decided to edit according to the base-manuscript principle; he deviates from the base manuscripts only in the case of obviously erroneous text (Bumke 1996, 608; 1999, 19-28, with detailed discussion of variants in the tradition of version ${ }^{\star} B$ ). In this, he was followed by Mertens (2004) in his base-manuscript edition of Iwein (after B) and Heinzle (2013) in his basemanuscript edition of the Nibelungenlied and Klage (after $B$ ).

The goal of limiting the genealogically reconstructive edition to a certain early stage in the history of the textual tradition (not necessarily with the quality of a version in Bumke's terms) has been realised without fundamentally departing from the idea of a fixed authorial text. The new edition of Stricker's Karl der Große by Singer (2016) can be mentioned as a recent example. Singer's recensio of the manuscript tradition led to five genealogically defined groups of manuscripts, beyond which it is not possible to penetrate further back in order to reach an archetype (Singer 2016, lxiv). From these five families, the text of the best one, relatively speaking, is edited, based on four manuscripts, for which a serviceable "recension formula" ("Rezensionsformel") can be derived from the "stemmatic structure" ("stemmatische Struktur") of the group; in the cases where the recensio leads to equally acceptable readings, "decisions are based on editorial judgement" ("entscheidet das editorische Urteil"), not least on the basis of the readings of the other groups ("die Konsultation der Lesartenverhältnsse der übrigen Gruppen”; Singer 2016, xxiv).

New methods of presentation are offered by digital editions. A salient example, with which we conclude, is the Parzival project by Michael Stolz (see the project website, parzival.unibe.ch/home.html). The project relates directly to the intensive efforts of twentieth-century research on the internal classification of Lachmann's manuscript classes ${ }^{*} D$ and ${ }^{*} G$. They are viewed as versions in Bumke's terms and have, in the two studies of the manuscript tradition emanating from the project (Schöller 2009; Viehhauser 2009), been supplemented by two further manuscript groups suspected of representing versions (see, in agreement, but with implied reservations, Schirok 2011, 313-314; Chlench and Viehhauser 2014). The aim, which has already been realised to a considerable extent, is a comprehensive documentation of the manuscript tradition with digital facsimiles, manuscript transcriptions, 
and synoptic readings of individual lines, which are linked together; the synoptic edition of the four versions according to the base-manuscript principle with apparatuses for each version; and, finally, still at an experimental stage (Stolz 2016), a reading text of version ${ }^{*} D$ (which Lachmann had already favoured) according to the base-manuscript principle, with variant readings of the other versions in the margin and a multilevel apparatus below the text.

Whereas in the early presentations of the project, attempts to elucidate manuscript relationships by means of tools which apply bioinformatic methods of cladistics/phylogenetics to textual relationships (see 5.1.3) were strongly emphasised (Stolz 2003), they are now more likely to be introduced in support of the results of research "according to strictly philological yardsticks" (Stolz 2016, 355; "nach streng philologischen Maßstäben"), in other words, stemmatics. Apart from the methodological problem of the transformation of an unrooted phylogenetic graph into an archetypedirected stemma (discussed in the case of Parzival by Chlench and Viehhauser 2014; in general, see Trovato 2017, 185-216; 5.5 above), which is indispensable (see the two illustrations in Stolz 2016, 356-357), the application of cladistics comes up first and foremost against practical limits, since it assumes the graphic normalisation of the manuscript texts that are to be compared (Chlench and Viehhauser 2014, 7071) - an effort that can probably be made only in the case of smaller sections of text (in the case of Stolz 2016, 210 lines in twenty-one textual witnesses); compare the experiences in Romance studies (7.3.4).

\section{Acknowledgement}

The text was translated from the German by David Yeandle (King's College London).

\section{Further reading}

The following publications offer further insights into the questions dealt with above: Bumke (1996, 1-88; on the tradition history and textual criticism of the courtly epic in the thirteenth century), Schröder (1998; opposing Bumke 1996 from the point of view of reconstructive editing), Heinzle (2003; basic questions in the edition of mediaeval German texts between reproduction and reconstruction), and Chlench and Viehhauser (2014; relationship between stemmatics and cladistics as exemplified by Parzival).

\subsection{Ethiopic}

\section{Alessandro Bausi}

The scholarly edition of Ethiopic (Gə'วz) texts can be taken in many respects as a paradigmatic example of practices common in other linguistic and cultural areas of 
Christian oriental studies as they have developed in the West since the Renaissance, particularly since the eighteenth century. It is a fact that, while the field of Christian Arabic and especially Syriac studies has, if not a longer, then definitely a richer tradition, Christian oriental studies shares some common basic features and has become a relatively coherent field at an academic level as well. For textual criticism and editing, the two main series, both established at the very beginning of the twentieth century and still active, the Corpus scriptorum Christianorum Orientalium (since 1903) and the Patrologia Orientalis (since 1904), emblematically represent albeit with some interruptions - a large part of the scholarly editorial activity carried out for the previous hundred years and longer. It is, however, important to stress a fundamental difference as far as ancient and late antique texts are concerned. Some traditions of the Christian Orient (Syriac, Coptic, and Armenian, to name the main ones) are important for the number and variety of transmitted texts (and the age of the relevant manuscripts), which are not limited to translations but also include many original texts. With only very few exceptions, however, most of the ancient (late antique) Ethiopic texts are translations from Greek, and therefore the philology of these ancient texts falls into the general typological class of editing translations (on which, see the several case studies in Macé et al. 2015 and some examples in 4.5 above).

\subsubsection{Ethiopic philology within Christian oriental philologies}

\subsubsection{Ethiopic philology and manuscript studies}

Despite the explosion of manuscript studies in recent decades, the issue of editorial practice - and particularly the utilisation of the stemmatic method in order to analyse or to edit and/or reconstruct texts - has not enjoyed much consideration in Christian oriental studies (an exception is Comparative Oriental Manuscript Studies: An Introduction; Bausi et al. 2015). Some contributions from Ethiopian studies in the last three decades are an exception, as I will show below. The accentuation of the archaeological and material aspects of manuscript research has, to an extent, been a disadvantage for the critical approach towards texts. Moreover, while many Ethiopic texts were and still are edited without any clearly determined or declared methodological approach, this practice is better understood in terms of a pre-Lachmannian state of the art of editing rather than in terms of a critical rethinking of stemmatic and reconstructive practices. On the other hand, focusing on single documents, or on the statistical evaluation of the average text circulating at a particular time, has substantially shifted the target of philological research towards single cases or the definition of successive stages in a tradition. This can be seen as a complementary task to that of determining the earliest textual phase (it is, in fact, a history of the tradition), but in practice it is usually meant as an a priori rejection of text-critical analysis. This line of action has, in my view, not replaced 
the stemmatic approach. Methodological considerations are further complicated by implications of political correctness in evaluating texts which, aside from their history and original form, have become accepted in a certain recension (vulgata) by institutions (typically, the national churches) which, in the opinion of some scholars, should be credited with a special status. This is, for example, the approach of the "Textual History of the Ethiopic Old Testament" (THEOT) project led by Steve Delamarter and Curt Niccum (see Jost 2015).

\subsubsection{Main features of the transmission of Ethiopic texts}

The first editorial methods applied to Ethiopic texts can be securely traced back to the environment of the Christian kingdom of Ethiopia, which was dominated by the cultural hegemony of the Church. A crucial role in the complex transmission of Ethiopic texts was played by the mediaeval adaptations of late antique written knowledge inherited from Greek-speaking Egypt and translated into Ethiopic early in the Aksumite period (ca. fourth to sixth century AD; for exemplary cases, see Bausi 2006a, 2015a, 2017a, 2018; Bausi and Camplani 2016). A decisive factor in prompting this mediaeval adaptation and revision was the presence of a new layer of Arabicbased texts, at times overlapping with and/or substituting the older ones. Also important was the fact that the literary language (Ethiopic, or Gə'əz) remained the language of education and writing, but had no longer been a spoken language since the tenth century at the latest. This had implications for orthography (several phonemes merged in the course of time and orthographical interchanges occurred, also posing questions of standardisation and normalisation; see Bausi 2016a). Nonetheless, the methods of dealing with texts in premodern Ethiopia have not to date been studied sufficiently to be the subject of even a cursory presentation (for some first attempts, see Bausi 2017b; Brita 2014; Lusini 2004; Mersha Alehegne 2011a). Yet this phase cannot be ignored, since it is an important component in the history of the tradition of Ethiopic texts. Despite the presence of a substantial corpus of older Ethiopic translations from Greek models going back to late Antiquity, all Ethiopic texts are transmitted by mediaeval manuscripts (starting from the twelfth/thirteenth century) with the sole exception of the New Testament, which is also attested by two late antique manuscripts. Manuscripts from before the fourteenth century are still extremely rare. For texts dating back to the Aksumite period, the typology of transmission is not so different from that of Greek and Latin classical texts, which, aside from epigraphical and papyrological witnesses, are mainly attested by much later manuscripts. A different case is that of texts which were created later in mediaeval times and that may be much closer to their earliest manuscript witnesses. Yet there are extremely few, if any, cases of preserved a u to graphs, and textual witnesses (manuscripts) rather distant in time from the creation of the texts are the norm.

\subsubsection{The earliest phases of editing Ethiopic texts in context}

Although they were vaguely known already in mediaeval times, the first close encounters of Western scholars with Ethiopic texts date from the Renaissance, when 
representatives of Eastern Christian communities travelled to and dwelt in Rome under the protection of the pope. In the case of Ethiopians, the ecumenical councils which saw the participation of oriental delegations, such as the Council of BasleFerrara-Florence of 1431-1445, and the eventual establishment of a permanent Ethiopian community in Rome, played a decisive role in promoting the development of Ethiopian studies. The challenges of editing and printing Ethiopic texts started relatively early in time compared with other Christian oriental traditions. The first printed Ethiopic text (not by accident the psalter, the most commonly read Christian Ethiopic book) dates from 1513, with a second four-language edition in 1518, both edited by Potken in Rome (1513) and Cologne (1518). As early as 1548 and 1549, a two-volume edition of the New Testament was printed in Rome by the Ethiopian Tasfā Șəyon with help of Italian scholars. A few Ethiopic texts were also printed in the seventeenth century, but it was only with Hiob Ludolf (1624-1704) that text editing was carried out in such a way that it can be methodologically evaluated. Ludolf's edition of the psalter (Ludolf 1701) still stands out as an advanced example of method in some respects: Ludolf based his edition on three manuscripts and the two available prints, and was well aware of questions of normalisation and standardisation. He did not hesitate to reintegrate ex nihilo missing verses or hemistichs when they were attested by the Greek and Hebrew text and missing in the Ethiopic version, where he explained their absence as due to the inaccuracy of the copyist, so that, ultimately, he fundamentally based his edition on his own iudicium (Ludolf $1701,2 \mathrm{v}-3 \mathrm{v}$ ). Nonetheless, this edition of the psalter, also furnished with a commentary, is still of great importance because of the critical comparison with the Greek and Hebrew texts on which it is based. Ludolf's works represent the high point in Ethiopian studies within the context of oriental studies in the modern age, as cultivated by humanists like Josephus Justus Scaliger (1540-1609) or NicolasClaude Fabri de Peiresc (1580-1637) and others, who had a strong interest in oriental cultures. This situation did not change with the Protestant and Catholic Reformations, after which the study of the Bible became even more important and had to be done in the original language in Protestant churches; this was a continuous source of impetus to oriental studies. The sixteenth and seventeenth centuries are also the period of the polyglot Bibles (from 1514 to 1657; see Wilkinson 2007), the last of which, edited by Brian Walton (1654-1657) in London, also includes an Ethiopic version of the psalter and of the Song of Songs along with a reprint of the New Testament from the Roman editio princeps.

\subsubsection{Christian oriental studies in their connection with classical studies}

The institutionalisation of oriental studies at European universities in the last decades of the eighteenth century (for example, in Germany at Göttingen) was undertaken in close connection with the extraordinary development of classical philology and still within the framework of biblical criticism. Theology still kept its central importance for oriental studies, and theologians in the Protestant tradition had to 
learn Greek and Hebrew. Besides the interest in the biblical text, the interest in ancient Judaism played a major role in keeping this ultimately humanistic tradition of Christian oriental studies alive. The overwhelmingly strictly religious character of Christian oriental texts determined a unification of Christian oriental texts under the umbrella of philologia sacra - a largely neglected aspect of Saidian orientalism (cf. Said 1978). Within this framework, the German theologian (theology was one of the main sites of Semitic studies) August Dillmann (1823-1894) refounded Ethiopian studies in the nineteenth century. He carried out substantial editorial work, not limited to but certainly focused on biblical and apocryphal texts dating from Aksumite times and typologically characterised by large gaps between the time of creation (presumably from the fourth to sixth centuries AD) and the date of the earliest extant manuscript witnesses (fourteenth century at the earliest). In doing so, whenever possible Dillmann carried out a recensio and oriented his editorial practice, as Ludolf had done, towards the available text of the Vorlage that he identified for a work, for example the Septuagint in the case of the Ethiopic Bible, without any prejudicial preference for a given manuscript (either codex optimus or codex vetustissimus). Ethiopic texts as edited by Dillmann, as well as by theologians and scholars in biblical studies in the decades immediately after his period - at least Robert Henry Charles (1855-1931) should be mentioned, since he dedicated much of his efforts to Ethiopic texts (see Bausi 2016a, 54-64) - were considered in terms of contemporary practice in biblical textual scholarship, particularly Septuagint studies (Erho and Stuckenbruck 2013 offer an overview of the manuscripts used for editing major Ethiopic apocryphal texts, but much less on the methods used, for which see still Piovanelli 1987, 1988).

\subsubsection{A splitting of traditions}

Dillmann's activity was deeply rooted in the long history of oriental and biblical studies and philologia sacra (see 7.1), and we can say that, up to the end of the eighteenth century, most of the editors of oriental texts had substantially shared the same methods and approaches as were used in classical philology: orientalists and classicists belonged to the same academic milieu and their attitudes largely overlapped. Yet the new method applied by Karl Lachmann (1793-1851; see 7.2) developed in a way that would eventually create a profound gap between philologia sacra on the one hand and classical philology (i.e. the disciplines using the stemmatic method conventionally placed under the name of Lachmann) on the other. In this respect, the non-adoption of Lachmann's method by oriental (non-classical) studies is a real landmark: it is at this point that classical studies (including Septuagint and Greek New Testament studies, and patristics to a large extent; see Castelli 2011) and oriental studies started to diverge more and more. While in the nineteenth century classical philology became more and more elaborate, oriental studies tended to become weaker and gradually less up to date and less methodologically oriented, since the mainstream was dictated now by classical and particularly Greek studies. 
As stated by Marchand: "In the early modern period, oriental philologists had pioneered many of these text-critical skills, but nineteenth-century orientalists almost by definition could not concentrate on one language; nor could they secularize their field with equal alacrity" (2009, 73).

If the development and secularisation of oriental studies at the end of the eighteenth century also marked the moment when oriental studies ceased to follow the development of the mainstream humanistic disciplines, one cannot disregard the fact that this was also due to some intrinsic features of the respective fields. Besides, the needs and starting point of oriental studies were completely different, since the majority of texts remained unpublished (somewhat similarly to mediaeval Latin and Byzantine studies) and only an absolute minority could be considered. It is not a surprise that, for a long time, publishing one manuscript (the most accessible but not necessarily the best, or "the best" if more were accessible, and so on), rather than editing a text, was the normal approach, and this trend has in many cases survived to the present day. In oriental studies, the content of a single manuscript understood exclusively as a text-carrier - has remained for much longer than in other fields a self-justified and sufficient object of study and research.

It is impossible to provide here even a draft history of Christian oriental text editing from a proper methodological perspective (a very short, slightly more detailed overview can be found in Bausi et al. 2015, 4-9, from which most of the following examples are taken). One must limit oneself to quoting a few examples, among many possible others, of orientalists who were familiar with the questions being discussed in their time. One case in point is that of one of the fathers of modern Coptology, as well as an outstanding classicist, Georg Zoëga (1755-1809). Zoëga applied principles that were very similar to those proposed by Friedrich August Wolf (1759-1824) but which he developed independently and in parallel. In his case, however, the specifically fragmented character of Coptic documentation, usually represented by dismembered codices, oriented his research in a decisive way, but it did not confront him with principles of philological reconstruction starting from multiple witnesses. It is important to point out that Zoëga did not feel the need to go beyond philologia sacra - probably he could not and did not want to do so, for various reasons, some of them being obvious (he worked at the papal court). Rather, he understood the potential interest of the almost virgin field of oriental Christian apocrypha, which he started to explore as far as Coptic texts were concerned (see Bausi 2015b).

\subsubsection{The base-manuscript edition, or "the normal way"}

In the course of the second half of the nineteenth century, philological discourse and methodologies were mainly developed within the field of classical and Romance studies (see 7.3). It is a fact that, with a very few exceptions - usually due to 
a stronger connection to biblical scholarship or classical studies - Christian oriental studies, even at the beginning of the twentieth century and later, by and large practised the base-manuscript method.

\subsubsection{The base-manuscript method}

As already mentioned, the practice of using a base manuscript was partly due to the particular kind of documentation being dealt with - very partially known and without the centuries-long research background of classical studies - but also reflected something akin to an acquired habit. All in all, it had little to do with the reasons put forward by Joseph Bédier (1864-1938) and his rethinking of the reconstructive Lachmannian method, and had much more to do with the continuation of a previous practice current in oriental studies, corresponding to what might be termed the "simple, normal way". In pre-Lachmannian classical studies, the editor normally started from the textus receptus and an existing edition which he emended, and recourse to codices was occasional and optional. In oriental studies, however, the editor normally started from one manuscript, since most of the time the text in question was to be published for the first time and was available in that manuscript only.

Exceptions to this trend can probably be found in every subfield, but they have never become the norm. An interesting early example is that of the Syriacist Arthur Amiaud (1849-1889). In the year of his death, 1889, following in the footsteps of Gaston Paris (see 7.3) both in content and method, he published an edition of the Syriac Alexis legends with an attempt at reconstructing the earliest text, stating in his introduction (with an explicit reference to Paris and Pannier 1872 in Amiaud 1889, x n1):

\footnotetext{
Nous n'avons pas affaire [...] à des compositions personnelles [...]. Si l'on entreprenait de publier une famille de telles œuvres, où chaque auteur respectant seulement les grandes lignes de la légende l'a traitée pour tout le reste avec une liberté presque absolue [...], tout ce qu'on pourrait faire serait de donner chacune entièrement et séparément. Mais ici où nous n'avons [...] que des copies plus ou moins exactes mais toujours sincères d'un même texte, le devoir de l'éditeur est de chercher à retrouver l'original ou à le restituer au moins dans la mesure $d u$ possible, et c'est là le but que nous allons poursuivre maintenant au moyen de la comparaison et de la classification de nos manuscrits. (Amiaud 1889, ix)

[We have not to deal [...] with personal compositions [...]. If one undertook the publication of a family of such works, where every author respecting only the general features of the legend has dealt with all other features with absolute freedom [...], all that one could do would be to present each one entirely and separately. But here, where we have only more or less precise copies of the same text, the duty of the editor is to try to trace the original or to restore it as far as possible, and this is the target we are aiming at now through the comparison and the classification of our manuscripts.]
}

Later, in 1922, Albrecht Götze (1897-1971), later a great Hittitologist, examined the manuscript tradition of the Syriac Cave of Treasures, and on the basis of the extant 
manuscripts he supposed the existence of an arch et y pe, reconstructing its physical structure (columns and number of lines) as well as that of a hyparchetype. He also established subgroups on the basis of mechanic al errors (loss of folia), and corroborated all this evidence with that of "verschiedene Lesungen und gemeinsame Neuerungen" [various readings and shared innovations], giving also a complex but clear s te mm a codicum (Götze 1922, 5-12).

In the second half of the twentieth century, Bernard Botte (1893-1980), the student of canonical oriental Christian liturgical texts, clearly advocated the consideration of versions as textual witnesses when undertaking the search for an original (see also Botte 1966, 177-179):

Les principes que je viens d'exposer ne sont pas neufs [...]. Je ne crois pas qu'on puisse procéder autrement sous peine de tomber dans la fantaisie. Il ne faut se fier aveuglément à aucune version. La question n'est pas de trouver "la bonne version", pas plus que dans une édition critique d'un texte grec on ne doit chercher "le bon manuscrit". Le tout est de faire un bon usage de tous les témoins. (Botte 1955, 168)

[The principles I have set out are not new [...]. I do not think one can proceed in any other way, without risking falling into fantasy. One cannot blindly trust any version. The question is not that of finding "the right version", any more than in a critical edition of a Greek text one must look for "the right manuscript". What is important is to make good use of all the witnesses.]

Hans Ferdinand Fuhs (Fuhs 1968, 31; see fig. 7.5-1 below, and later also Fuhs 1971, 25) has been credited with the first proposal of a stemma codicum for the edition of an Ethiopic text (Lusini 1988, 212n3), but the very first one was probably proposed by Louis Guerrier and Sylvain Grébaut in their edition of the Testament of Our Lord in Galilee in 1912 (Guerrier and Grébaut 1912, 173 [33]). Another early stemma codicum was proposed by Adolf Grohmann in his 1913 edition of several versions of the Vision of Shenute, particularly in the section dedicated to the Ethiopic tradition (Grohmann 1913, 198). Grohmann's contribution contains several interesting observations on the relationship of the manuscript witnesses (gained from applying a reconstructive method in order to determine the mutual relationships between them), as well as other observations concerning the establishment of the text, and presupposes reflection on the role of the introduction in a critical edition.

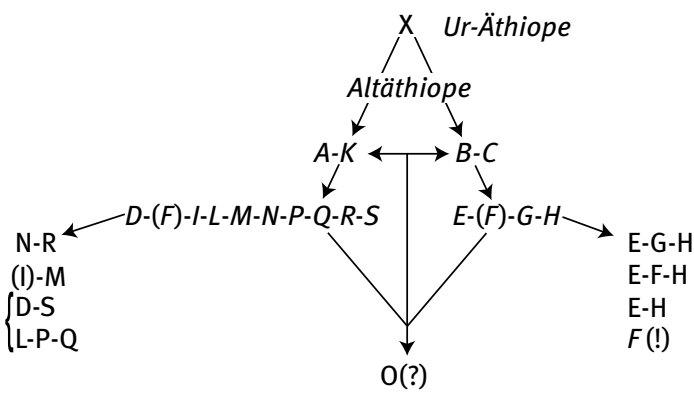

Fig. 7.5-1: Stemma codicum of the Ethiopic version of Micah. Source: Fuhs $(1968,31)$. 


\subsubsection{The purported reasons behind the base-manuscript method}

Returning to the main series of text editions mentioned above, it is obvious that the base-manuscript method has largely been applied in them, with only very few exceptions. In the case of Christian oriental studies in particular, René Draguet's (1896-1980) credo of the base-manuscript method long dominated the Corpus scriptorum Christianorum Orientalium (CSCO), which Draguet directed from the late forties (1948) until his death (see Mengozzi 2015). Draguet himself canonised his suggested method for Syriac texts in a controversial contribution (Draguet 1977), a major part of which was dedicated to technical concerns of layout and printing and very little to proper text-critical methodology. It recommended a simple reproduction of the best manuscript's text - taking into consideration its age and legibility with all its errors included. Draguet's "best manuscript" is thus simply the most suitable for the representation of the form; it is not even the best manuscript a posteriori, that is, the manuscript most similar to the critically established text that emerges from a recensio. It is therefore different - one might say worse - than the codex optimus (or codex vetustissimus, and so on) of pre-Lachmannian philology, which was a base manuscript whose errors could be corrected ope codicum and ope ingenii.

Ethiopic texts were no exception to this trend. If one browses through the introductions to editions published in the CSCO and Patrologia Orientalis series looking for explanations of why this method was applied, one will be soon disappointed. I have carried out this task in two contributions where more details are provided (Bausi 2006b, 2008), and I will not repeat the predominantly discouraging results here. The consideration of later editions does not change this picture (see e.g. Bausi 2009, 2010a, 2015c). As an advisor for the CSCO series, I have myself experienced the difficulty of ensuring respect for minimal standards such as, for example, consideration of all known available manuscripts (all the more so when digital reproductions are easily accessible). Almost all editions in these series are introduced by the same formulaic considerations, in a few cases by additional short comments, often with hardly more than a couple of words; just one representative example is: "Vulgatur textus codicis A notatis variantibus in B" (Arras 1986, v) [The text of co$\operatorname{dex} A$ is published, the variants from $B$ being noted].

\subsubsection{Ethiopic philology in the past thirty years}

Little more interest has generally been displayed in using the so-called n e o - L a c h mannian approach (see 2.4) in oriental studies (see Witkam 1988, 2013). Among the exceptions, one should mention the edition of the Ethiopic version of the Life of Saint Alexis by the renowned orientalist Enrico Cerulli (1898-1988; see at least Bausi 2016b, 191-194, with further references), where different recensions as well as 
individual authorial variations were distinguished, particularly in the more recent manuscripts, which Cerulli attributed to specific characteristics of this very widespread hagiographical text:

Les observations qui précèdent font voir que les mss de la Vie d'Alexis se prêtent peu à l'établissement d'un stemma codicum rigide; ils ne diffèrent pas en cela de ceux des compositions hagiographiques du moyen âge et en particulier du moyen âge oriental. Une critique prudente doit avoir égard à la fantaisie des scribes, aux préoccupations des monastères où furent copiés les mss, et aux habitudes mêmes des scriptoria. En ce qui concerne particulièrement l'Éthiopie, il faut tenir compte que les Actes étaient destinés à la lecture dans les monastères, où on les divisait en sept sections égales pour les sept jours de la semaine, ou encore entièrement, dans une séance unique, dans certains couvents ou églises à l'occasion de la fête du Saint. Toutes ces circonstances pouvaient aisément conduire à des additions, ou à des suppressions. (Cerulli 1969, xv)

[The preceding observations show that the manuscripts of the Life of Alexis lend themselves little to the establishment of a rigid stemma codicum. They do not differ in this from those of the hagiographical compositions of the Middle Ages and especially of the Eastern Middle Ages. Prudent criticism must have regard to the fantasy of the scribes, the preoccupations of the monasteries where the manuscripts were copied, and the very habits of the scriptoria. Concerning Ethiopia in particular, it must be borne in mind that the Acts were intended for reading in the monasteries, where they were divided into seven equal sections for the seven days of the week, or entirely in a single sitting, in certain convents or churches on the occasion of the feast of the saint. All these circumstances could easily lead to additions or deletions.]

Even in this case, however, Cerulli did not use a base-manuscript method. Although he distinguished three groups (ancient, intermediate, and modern) among the fifteen manuscript witnesses he used, he did not adopt any base manuscript for each of them. He edited what he thought was the most ancient version based upon the three manuscripts of the ancient group and provided the variants of all other manuscripts deviating from the older text form (fig. 7.5-2 below). Cerulli observes a tendency that is well known in hagiographical texts (for further references, see Bausi 2014a, 57n6), but it cannot be treated as a universal truth. But it is true in particular for texts which have a very rich manuscript tradition and enjoyed good fortunes and wide dissemination. This condition must be verified for each single case, and there is no getting around this.

In recent decades, remarkable achievements have, indeed, been reached in studies on the text of the Bible and apocrypha (e.g. the editions of the Gospels of Mark and Matthew by Zuurmond 1989, 2001, and of the Gospel of John by Wechsler 2005; the best overview is in Zuurmond and Niccum 2013), although even in this field the state of the art is very far from being uniform (cf. e.g. the editions by Tedros Abraha 2001, 2004, 2014; see also the general remarks in Bausi 2016a, 73-80). A scholar like Ernst Hammerschmidt (1928-1993), and even someone of the calibre of Edward Ullendorff (1920-2011), one of the editors of the Book of Enoch (Knibb and Ullendorff 1978), still justified the use of photographic reproductions for editing Ethiopic texts (for details and references, see Bausi 2016a, 53n28). Obsessed by the 


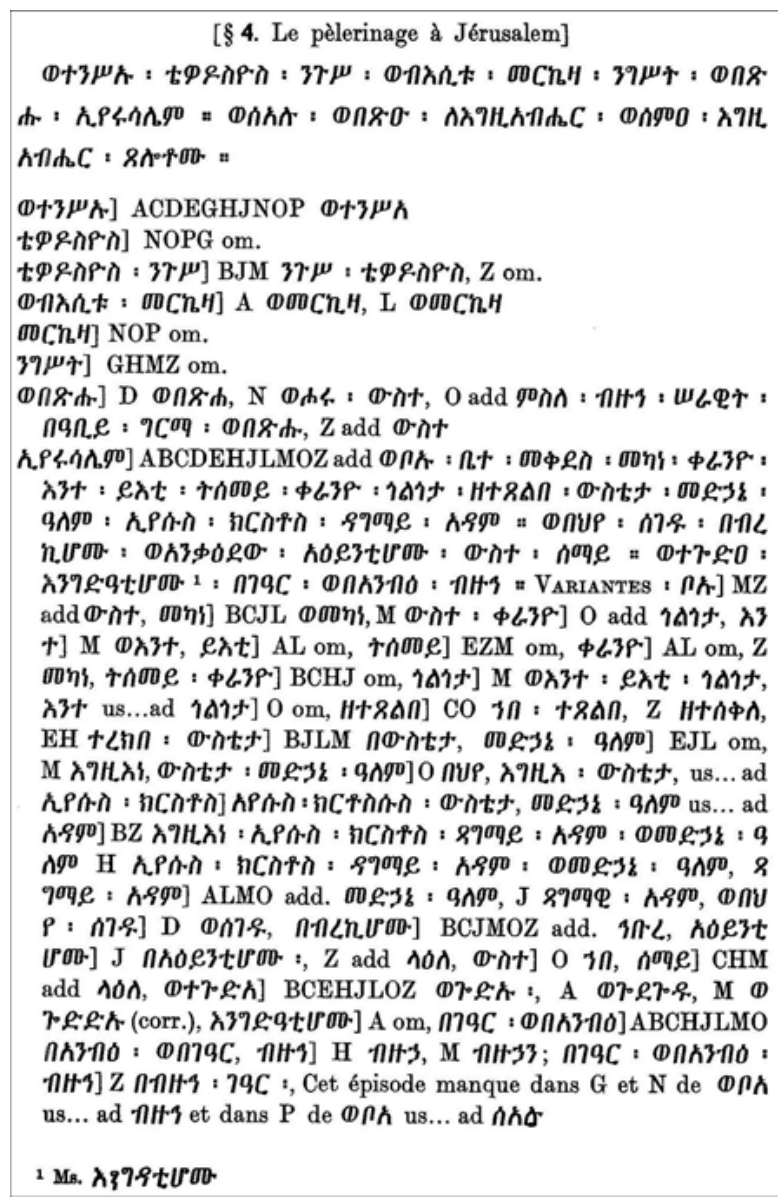

Fig. 7.5-2: Edition of the Ethiopic version of the Gadla Gabra Krastos [Life of St Alexis]. Source: Cerulli $(1969,6)$.

importance of documenting the evidence, these editors advised reducing editing to the making of facsimiles, and apparently attached much less importance to critical editing as a specific task of its own.

In 2015, almost forty years after the publication of the edition of the Book of Enoch, the former main editor, Michael A. Knibb, who had worked in consultation with Ullendorff, published an edition that marks a decisive change of trend. Knibb's edition of Ezekiel (Knibb 2014, 2015; see also Knibb 2017) has a long exemplary introduction that culminates in a stemma codicum where the main aspects of the manuscript tradition are tentatively represented (Knibb 2015, 37). Most of all, Knibb's edition does not apply any base-manuscript method and attempts instead to reconstruct the oldest attainable layer of the text. This decisive change is the 
result of the debate and criticism of the base-manuscript method that have, to some extent, animated the past thirty years of Ethiopic text editing.

\subsubsection{Paolo Marrassini and the application of a neo-Lachmannian approach}

An important novelty for editing Ethiopic texts was represented by the work of Paolo Marrassini (1942-2013), one of the most outstanding scholars in Ethiopian studies of the past forty years (on him, see the introductory papers to his Gedenkschrift, Bausi, Gori, and Lusini 2014; Lusini 2014). Marrassini used with full awareness a neo-Lachmannian approach in a number of critical editions of Ethiopic texts, both original (hagiographical and historiographical) and translated ones (apocryphal writings, for example the Ethiopic version of the Apocalypse of Peter). Marrassini started with the edition of a hagiographical text in 1981 attested by four manuscripts (Marrassini 1981), for which he proposed a stemma codicum according to which he reconstructed a critical text (fig. 7.5-3). His work had the honour of being mentioned in the Breviario di Ecdotica by Gianfranco Contini as a first example of the stemmatic method in Semitic studies (Contini 1986, 66, in a section added to the first edition and entitled "Postilla 1985"). Moreover, besides producing a series of critical editions (at least Marrassini 1981, 1993, 1995, 2000, 2003), Marrassini defended his method in a series of methodological contributions where he approached, among other things, questions of criticism of form and substance and of the relationship between linguistics and philology, and addressed the question of the role of the introduction in a critical edition, and what to do with punctuation in manuscripts (Marrassini 1987, 1992, 1996, 2008a, 2008b, 2009). Even in Marrassini's work, there are obviously points to be revised. It is, for example, apparent, in light of further research and when considering more manuscripts, that the manuscript tradition of the Life of Kiros (a very widespread hagiographical text) is much more complex than he had thought (Marrassini 2004; see Krzyżanowska 2015).

One specific aspect of Marrassini's work is that of having established a school, both in Europe (pupils of his are philologists with chairs in Copenhagen, Hamburg, Naples, and Paris) and in Ethiopia. In fact, in Addis Ababa an MA and a PhD programme in philology were established and have started to yield encouraging results. More editions and studies based on the stemmatic method have been produced, and a few of them are also starting to be published, some of them in international series

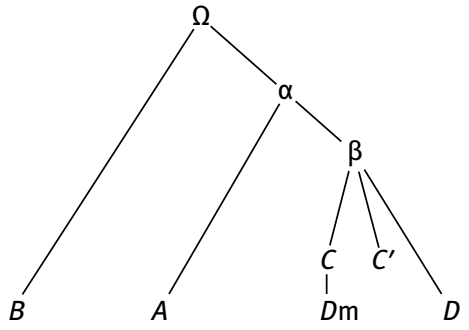

Fig. 7.5-3: Stemma codicum of the Gadla Yohannas Məśrāqāwi [Life of John the Oriental]. Source: Marrassini (1981, xxvi; revised according to the errata corrige). 
(Amsalu Tefera 2015; Hagos Abrha 2011). Pupils of Marrassini's pupils are doing the same (Brita 2007; Pisani 2013, 2015; Solomon Gebreyes 2019; Villa 2019), and more such editions are underway (cf. e.g. Hummel 2015, 2016; cf. also Mersha Alehegne 2011b; Yosef Demissie 2015). A few still-unpublished critical editions have also been produced as MA theses. The case of one thesis is remarkable: an MA thesis consisting of a new critical edition of the Gadla Qawsțos (a hagiographical text already published by Raineri 2004), was published under the auspices of the national Orthodox Church of Ethiopia (Ḩəruya 'Ermyās 2014, 2014-2015). This is the first stemmatically reconstructed text ever published by the Ethiopian Orthodox Tawāhəodo Church. In comparison with what was said at the beginning concerning the standards of traditional text editing (consider the case of a recent edition for which it was possible to determine the ancestor of the manuscript on which the editor produced his own personal redaction; Bausi 2017b), this definitely marks a new trend. The stemmatic method proves, even in these cases, invariably effective.

\subsubsection{The past decade}

Notwithstanding the many texts that have been published in recent decades, there have been very few contributions explicitly dedicated to questions of critical editing. In July 2003, a plenary session of the Fifteenth International Conference of Ethiopian Studies in Hamburg was dedicated for the first time to "Current Trends in Ethiopian Studies: Philology”. To my knowledge, the most relevant - but also the only contributions of methodological character on Ethiopic philology remain, with very few exceptions, those by Marrassini or his pupils (Marrassini 1987, 1992, 1996, 2008a, 2008b, 2009; Lusini 2005, 2017; Bausi 2006b, 2008, 2010b, 2014b, 2015a; as far as reflexes in Ethiopia are concerned, cf. Baye Yimam 2008; Hussein Ahmad 2008; Shiferaw Bekele 2008; Moges Yigezu et al. 2006).

If Marrassini's school has adopted and applied, where possible - it should be taken for granted that everyone is aware of the complexity of editing - a neo-Lachmannian approach (for one of the most recent examples, see Bausi 2017c and fig. 7.5-4 below), there are also different views. A scholar who has clearly expressed a different view on editing Ethiopic texts is Manfred Kropp. He has devoted extensive work and an important monograph to disentangling the manuscript tradition of the Ethiopic royal chronicles and related texts (Kropp 1989), and has published several text editions (Kropp 1988a, 1988b, 1994, 2016), preparatory essays (Kropp 1985, 2011), and focused reviews (among the recent ones where methodological remarks are clearly expressed, see Kropp 2015a, 2015b). In his footsteps, to name some other authors, Anaiis Wion has, for example, rightly criticised the standardisation carried out by Carlo Conti Rossini (1872-1949) in editing documentary texts (Wion and Bertrand 2011, on Conti Rossini 1909), although one may strongly disagree that this is a good example of the adoption of Lachmann as a model by scholars in Ethiopian studies (see Bausi 2017-2018). Finally, a contribution by Reinhard Meßner 
1300

1400

1500

1600

1700

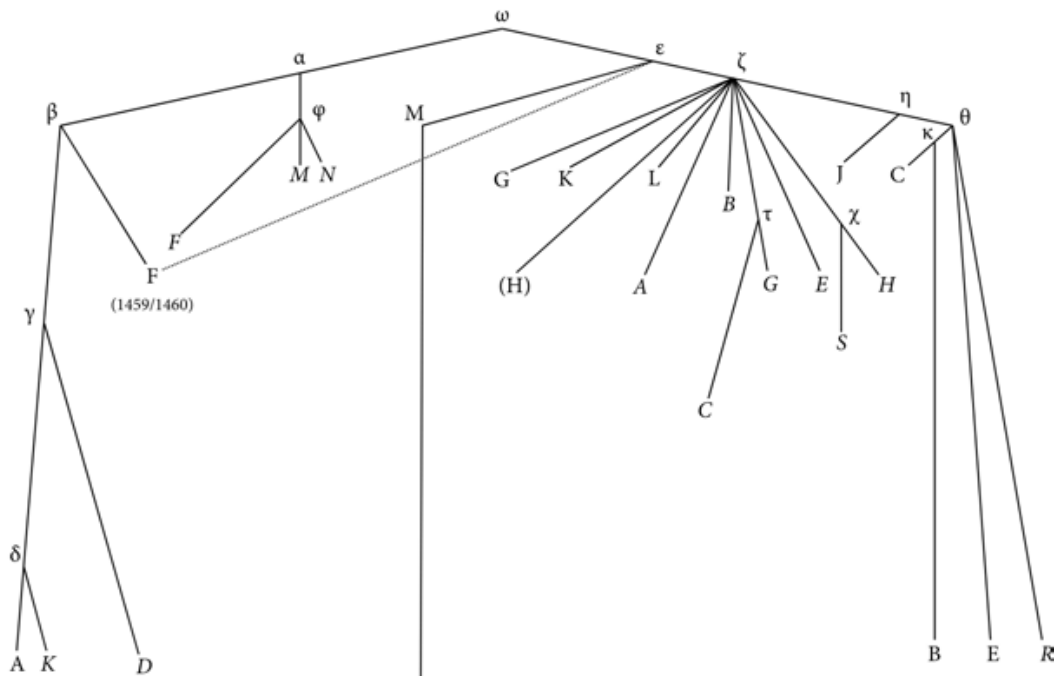

1800

1900

900

Fig. 7.5-4: Stemma codicum of the Gadla 'Azqir [Acts of Azqir]. Source: Bausi (2017c, 351).

(2007) on editing liturgical texts from the point of view of the researcher interested in "living texts" of liturgical use can also be mentioned.

Kropp, on the other hand, has expressed on several occasions a radically sceptical view of stemmatic and neo-Lachmannian approaches. He has noted, on the one hand, that, in his opinion, the practical results are in the end not far from what would result if a base-manuscript method were accepted; but, on the other hand, he has not clearly proposed a soundly based alternative method or even precisely motivated why the stemmatic method should not in principle be accepted, given all that it can offer. He also, even less correctly in my opinion, regards the solution of editing several distinct redactions to be contradictory to the stemmatic and reconstructive approach, something that was proposed for some portions of the Gadla Libānos (Kropp 2015a) where more authorial redactions clearly appear, each of them already attested by more witnesses. This is, by the way, a fortunate case where a conjectural emendation to the editio princeps (published by Conti Rossini 1903), which I could not have in the text as I would have wished due to the fierce opposition of the series advisor, eventually appeared to be the actually transmitted text when new manuscripts of the redaction in question were discovered (see Bausi 2003, 2014a).

All in all, the impression remains that some aspects of criticism of the use of the stemmatic method are rooted in a lack of familiarity with the method itself. We can be confident that what Paolo Trovato has undertaken with his remarkable book, 
now already in a second edition (Trovato 2017), will also profit the textual criticism of Ethiopic and Christian oriental texts. All those who criticise the inanity of the effort required by the stemmatic approach without clearly adopting a position of their own, do not, in my view, touch upon the core of the problem: that without a stemmatic approach, when this method allows clear results (and there are definitely cases where it does), it is simply impossible to provide any sound assessment of the value of the individual witnesses. It should probably suffice to repeat here the words of Alphonse Dain: "Le concept de manuscrit de base, qui rencontre tant de faveur, est un concept antiphilologique” (Dain 1964, 171) [The concept of the base manuscript, which meets with so much favour, is an anti-philological concept].

In Dain's usage - in case it is necessary to recall this - le manuscrit de base is really the base text methodologically speaking, and not the manuscrit de surface, that is, the "reference manuscript for the linguistic surface", the "surface manuscript”, as in the neo-Lachmannian tradition (Trovato 2017, 346).

\section{Further reading}

A useful selection of further reading material and a general bibliographical orientation on Christian oriental philologies can be found in the chapter on textual criticism and text editing in Comparative Oriental Manuscript Studies: An Introduction (Bausi et al. 2015, esp. 324-327). The broadest, most systematic and updated information on the manuscript traditions of single Ethiopic texts and works is offered by the relevant articles in the five-volume Encyclopaedia Aethiopica (Uhlig 2003-2014), albeit with quite uneven approaches. Further information and bibliography on single texts can be found on the portal of the long-term project "Beta mașāḥəft: Manuscripts of Ethiopia and Eritrea", funded by the Union of the German Academies of Sciences and Humanities through the Academy of Hamburg. Within the traditions of the Christian Orient, the Syriac domain is largely covered by the international project syriaca.org (The Syriac Reference Portal), and Coptic by the recently launched European Research Council project "PAThs: An Archaeological Atlas of Coptic Literature" at the Sapienza University of Rome, which has integrated data from previous projects. Caucasian traditions (Armenian and Georgian) are largely represented on the TITUS portal of the University of Frankfurt (titus.uni-frankfurt. de). For the delicate linguistic questions posed by Christian Arabic texts, see the contributions by Paolo La Spisa (2012, 2015).

\subsection{Hebrew}

Chaim Milikowsky

The major group of texts in Hebrew which will be discussed in this section is the rabbinic corpus, a collection of texts, each of which is related to one or more other 
texts in the collection, which are generally dated to the second through sixth centuries $\mathrm{CE}$. None of these texts are attributed in any manuscripts or in any testimonia to an author or editor. Most of them, in fact, should not be attributed to an author, but were generated by the accretion of textual matter, its collection together and subsequent redaction. Some have argued that no one moment and/or process of textual formation should be presumed for any of these texts, and that they were constantly in a state of becoming, but the extant evidence does not support such a position.

\subsubsection{Language and boundaries of the corpus}

Some of these texts are written solely in Hebrew, while others contain a mixture of Hebrew and Aramaic. The texts commonly assigned to this corpus are traditionally divided into two sets of two groups. One element of differentiation focuses upon date and the other upon subject matter. The earlier group of texts is ascribed to the Tannaitic period and the later one to the Amoraic period. In terms of subject matter, there are texts which are primarily legal - halakhic - in nature and there are those which are not legal but contain biblical exegesis, narratives and anecdotes, riddles and apophthegms, and ideas and beliefs, and are termed aggadic. Many texts exhibit a combination of both halakhah and aggadah.

Two texts within this corpus, the Mishnah and the Babylonian Talmud, have had a special status within Jewish tradition for the last two millennia or so. The Babylonian Talmud is a sort of expanded commentary on the Mishnah, and since the high Middle Ages most manuscript and printed versions of the Talmud have included the Mishnah within it. This entity has been the basis of Jewish law and practice since its formation, and therefore has been copied thousands of times, although for a variety of reasons, only a small number of manuscript copies survive; for most tractates (as each individual unit of the Talmud is generally called), it is less than ten. It should be pointed out that the Babylonian Talmud is a large composition, consisting of approximately nine and a half million characters (including spaces), and consequently was only very rarely copied in its entirety. It is divided by subject into orders and tractates, and generally one, two, or three tractates were copied at a time, although a small number of manuscripts contain more. This historical context means that the textual history of these two works is radically different from that of all other works in the rabbinic corpus and requires a separate discussion.

The puzzles regarding the transmission process of the Babylonian Talmud are much greater than those of other rabbinic compositions. The recensional variation found in some tractates suggests the possibility that at an early stage of the oral (?) - transmission there was no urtext, or that passages not stemming from the urtext entered into the text at this time. Furthermore, there is no doubt that contamination between the various branches of the textual tradition was rampant throughout its transmission history. Clearly, then, textual analysis of any sort can 
be of only limited help for the textual critic of the Babylonian Talmud (see Sussman 1990, 92n160; Milikowsky 1988).

\subsubsection{A very condensed history of philological practice in rabbinic studies}

Relatively few rabbinic works have had the privilege of being the focus of extended textual analysis (of any sort). For many of the classic works of rabbinic literature, there exists no scholarly edition of the entire text, nor even lists of its variae lectiones. A comparison with Greek and Latin literature or with the New Testament (see 7.2 and 7.1 respectively) indicates how embarrassing the situation is. Instead of the sanguine possibility of various editors arguing over correct readings - only two foundational rabbinic compositions, the Mekhilta on Exodus and the Sifre on Numbers, have been edited critically twice. Scholars of rabbinics consider themselves fortunate when manuscript material has been made available, even if the citations are haphazard and the method non-critical.

Some sort of limited critical editing in rabbinics began in the eighteenth century, about a hundred years after the beginnings of the critical editing of classical literature (see 2.1.4). Similarly to the situation with Greek and Latin texts, editors initially combined together in one section at the bottom of the page textual notes and commentary. In most of these semi-critical texts, no attempt was made to delineate the textual history of the work, other than of the most basic, elementary kind.

The first rabbinic text which was edited in what became the standard format of critical editions was Zuckermandel's edition of the Tosefta (Zuckermandel 18771881). As was common then, often the lemma is omitted; as was common then and now (in classics), only a small fraction of the variants are cited. All other critical editions of rabbinic texts have both an apparatus of variants and either annotations or a commentary. By my count, eighteen critical editions of various compositions in rabbinic literature have been produced from Zuckermandel's edition until today. None of these editions is of the Mishnah, and only one is of a tractate of the Babylonian Talmud. In addition to these critical editions, and to the semi-critical editions mentioned above, a number of orders of the Mishnah and tractates of the Babylonian Talmud have been published in different types of variorum editions.

Within the past decade, the situation has progressed considerably, both with regard to the print publication of critical editions with concomitant textual analysis and with regard to the digital dissemination of manuscript images and collated transcriptions of variant versions of rabbinic compositions.

\subsubsection{Editorial methodology}

For heuristic purposes, I will schematically (and somewhat simplistically) divide critical editorial methodology into three groups. This scheme is roughly based upon Greetham (1987; see 6.1 above for a typology of editions in general). 
One method is that of the best-text edition, as it is referred to by mediaevalists, or of the codex optimus, the term often used by classicists. The proponents of this method maintain that the editor should use one manuscript as the base for the entire text of the work, changing its readings only when they are "impossible", that is, clear scribal errors, and not when they are simply "improbable”, to quote Vinaver (1939, 369).

Another method of editing texts is grounded in the stemmatic analysis (or genealogical analysis) of the textual witnesses. In this type of analysis, the scholar determines the relationships among the various manuscripts by locating the errors common to two or more manuscripts. After determining which manuscripts join together to form families, that is, derive from a common exemplar, the editor can use this information in order to conclude which variants are attested by more than one independent branch of the tradition, and thereby reconstruct the most original text that the extant documents allow (see 2.2).

Ideally, the establishment of the relationships among the manuscripts allows the editor to evaluate the importance and cogency of the variant readings for each and every passage. In practice, the situation is often more complicated, and textual analysis is insufficient in and of itself to establish the "best" reading. Nonetheless, at the very least, when the relationships among the manuscripts have been clarified, many readings which cannot be disallowed on the basis of the internal criteria of cogency can be firmly and unhesitatingly rejected.

The last method of editing we will mention here is that of radical eclecticism. An editor using this method will decide which is the preferable reading for each and every word in the work. He is deferential neither to the text of any document nor to any systemic analysis; all textual decisions are entirely dependent upon the editor's insight and judgement. This method is the only viable one when stemmatic analysis is not feasible - generally because of heavy contamination between the various branches of the stemmatic tree - and the editor is not willing to use the best-text method.

It is essential to note that all three editions are eclectic editions: any text presented by an editor who does not purport to give his readership an exact transcription of one document and presents a text of the work including at least one deviation from the text of the document serving as his base - such a text must be termed an eclectic text (see 6.1.1). What distinguishes the radical eclectic mode of editing from the other modes is the prior decision of the editor to use only his critical judgment - or possibly, his critical delusions - for the generation of his edition.

For some unfathomable reason, it is the general practice among philologists of rabbinic literature to distinguish between only two types of critical editions, the "diplomatic" and the "eclectic". The first term is used to denote the product of what was called above the best-text method of editing, and the second for every other type of critical edition. This nomenclature is faulty, and should not be used. As already noted, the meaning of the term "diplomatic edition" among textual scholars 
is precise and unambiguous. It can be used only when the editor means to present the text of a document, and not that of a work; such an editor makes no corrections to the text of the document, or, at most, if a correction is made, both the incorrect reading and the correct reading are included in the base text.

\subsubsection{The editorial methodology used in editions of rabbinic literature}

The three types of critical editions described above are ideal types, but nonetheless serve well to delineate the options available to the prospective editor. With regard to rabbinic literature, the prevalent mode has been that of best-text editing; indeed, many editors pride themselves on how little they have changed the manuscript upon which they based their text, though of course not every editor uses the same criteria to decide which readings of the base manuscript are corrected (see Lieberman 1955-1988, 2:5-6).

In this manner, Julius Theodor and Chanoch Albeck (1965) edited Bereshit Rab$b a$, H. Saul Horovitz (1966) edited the Sifre on Numbers, Horovitz and Israel Abraham Rabin (1960) edited Mekhilta d'Rabbi Yishmael, Saul Lieberman (1955-1988) edited the Tosefta, Mordecai Margulies (1972) edited Vayyiqra Rabba, Bernard Mandelbaum (1962) edited Pesiqta de-Rav Kahana, Avigdor Shinan (1984) edited Shemot Rabba I, and Menachem I. Kahana (2011-2015) edited the Sifre on Numbers, to name just some examples.

The radical eclectic method was used by Henry Malter (1930) in his edition of the Ta'anit tractate of the Babylonian Talmud and by Jacob Lauterbach (1933-1935) in his edition of Mekhilta d'Rabbi Yishmael. In addition, in those chapters of Vayyiqra Rabba absent from London, British Library, Add. 27169 - the base manuscript for the greater part of the text - Mordecai Margulies leaned towards this method.

\subsubsection{Louis Finkelstein's edition of Sifre Devarim - and its consequences}

It is often thought that Louis Finkelstein used a radical eclectic mode of editing to produce his edition of Sifre Devarim $(1939,1969)$. This is not the case. Prior to the appearance of this edition, Finkelstein had published a stemmatic analysis of the textual tradition of Sifre Devarim (1931-1932), and it was on the basis of that analysis that he made many decisions in his presentation of the text. It should be noted that Finkelstein's edition originally appeared in 1939, approximately a month after the outbreak of World War II. Because of the need to publish in a hurry, Finkelstein could not finish his introduction, in which he would have outlined his method, and only included a page-long preface (see the prefaces to the first and second editions, both in Finkelstein 1969, n.p.).

In fact, Finkelstein's edition was the only edition of a rabbinic composition whose editor used the principles of stemmatic analysis in the presentation of the 
text until the second decade of the twenty-first century. The reasons for this are several and varied. One contributing factor is the fact that, in the Germany of the late nineteenth and early twentieth centuries - the time when many of the scholars who established the field of rabbinic philology received their training in German universities - a very conservative tendency prevailed in many of the centres of classical scholarship (see Kenney 1974, 126-127; Tarrant 1989, 122). Another point to consider is that, prior to World War II, the two centres of rabbinic philology were Germany and Palestine, while Finkelstein, who was born, trained, and taught in the United States, was an outlier.

Most important, however, were the two reviews of Finkelstein's edition (which appeared as separate fascicles prior to its final publication in 1939) written by Jacob Nahum Epstein (1936-1937) and Saul Lieberman (1937-1938), the two doyens of rabbinic philology in the middle years of the twentieth century. Both were negative.

The crucial point here is that any editor who decides not to use the best-text mode of editing - it is immediately obvious that this mode demands of the editor the least amount of textual acumen - takes upon himself a tremendous responsibility, and offers up his acumen and his critical judgement to the acclamation or, alternatively, the disparagement of all. It was this critical judgement of Finkelstein which was put to the test and found lacking, and that is why his edition was criticised extensively by Jacob Epstein, and, somewhat more moderately, by Saul Lieberman in their reviews.

Epstein opposed in principle the introduction of variants from other witnesses into the text without clear indication of this fact (unless the manuscript used as the base is clearly corrupt). This is especially ill-advised with Tannaitic literature, which had a long history in both oral and written form, and whose variants may be based upon ancient traditions. He continues with a long list of passages where Finkelstein's emendations of the text are unjustified. Epstein explicitly states in his review that Finkelstein's eclectic editorial method “is intrinsically dubious" (1936-1937, 375).

These comments by Epstein should be compared to what he published eight years earlier in a programmatic article on desiderata in the field of Talmudic studies: "We are lacking a scientific edition of the Mishnah, critical and precise, an edition which adjudicates and determines readings [...] by means of the use of manuscript versions” (Epstein 1925, 5).

Lieberman, though less critical of Finkelstein, also objects to his proclivity towards precipitate changes in his text. His objections are similar to those of Epstein, but he elaborates on the theoretical basis for his opposition. He quotes a sentence from his review of a different rabbinic text: "It is necessary to distinguish between a scribal error which has been introduced into a group of manuscripts and a tradition (either correct or incorrect) which was accepted in specific lands" (Lieberman 1937-1938, 324). Lieberman asserts that the editor should not mix together readings of different manuscripts of the same work, for at times we are dealing not with scribal errors but with scribal corrections, corrections which were made consciously and 
on purpose in accordance with the views prevalent in the country of the scribe. He expresses no opposition to the theoretical applicability of stemmatic theory to rabbinic texts, only to the practical application of that theory to the editing of the texts, that is, presenting to the reader a heavily eclectic text.

In his review of Lauterbach's edition of the Mekhilta, Lieberman acclaims Finkelstein's (1934-1935) stemmatic analysis of the manuscripts of the Mekhilta and says that such analysis is necessary for a "correct evaluation of the Mekhilta text" (Lieberman 1935-1936, 57). See also what Lieberman wrote about eclectic editions in his edition of the Tosefta (1955-1988, 1:12).

\subsubsection{Beyond the consequences of Finkelstein's edition}

The pronouncements of Epstein and Lieberman were considered definitive, and, as a consequence, no editions of rabbinic texts subsequent to the 1930s used any but the best-text method of editing - until 2013, when I published a critical edition of the rabbinic chronography Seder Olam (Milikowsky 2013). In this edition, a base textual witness was used for each section of the text, but it was changed hundreds of times during the course of the edition, not only when the base witness had what we, following Vinaver, earlier called "impossible" readings, but also whenever the stemmatic analysis indicated that the reading of the base witness was secondary (see fig. 7.6-1).

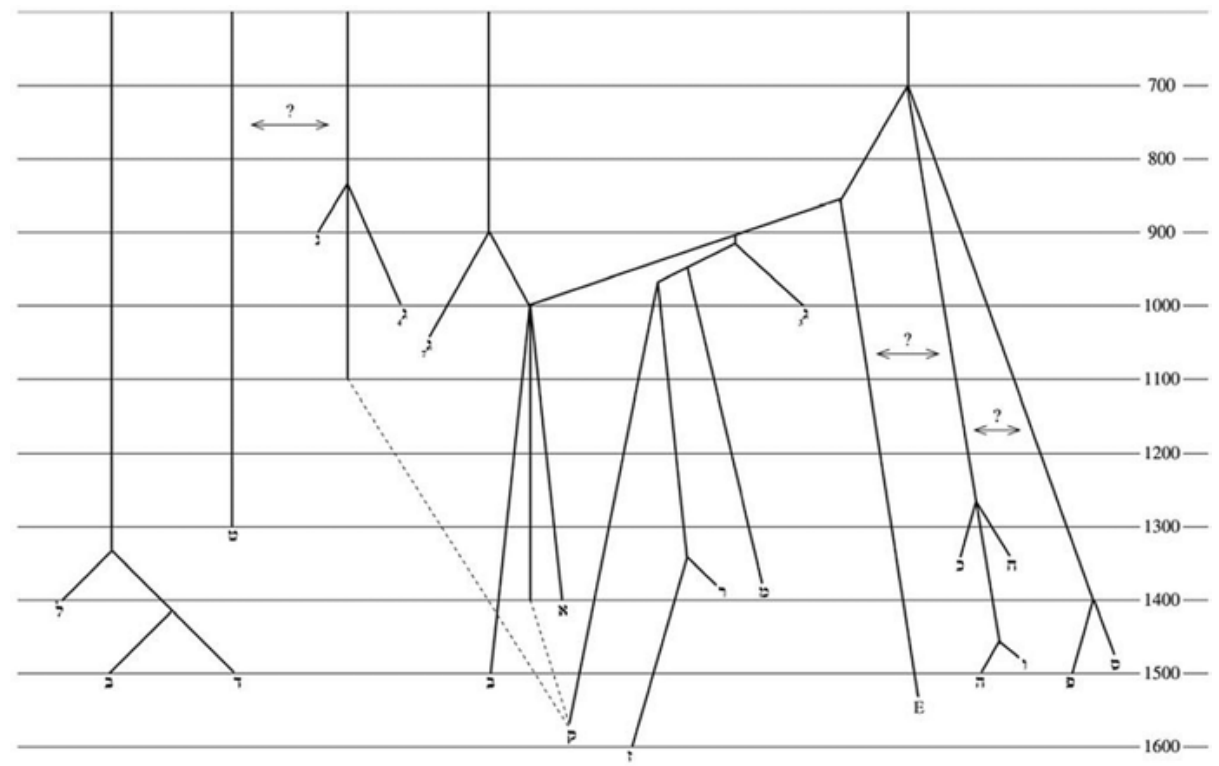

Fig. 7.6-1: Stemma of Seder Olam from Milikowsky (2013, 1:189). All the lines stem from one original; it was simply too difficult graphically to connect all the lines to one point at the top of the stemma. 


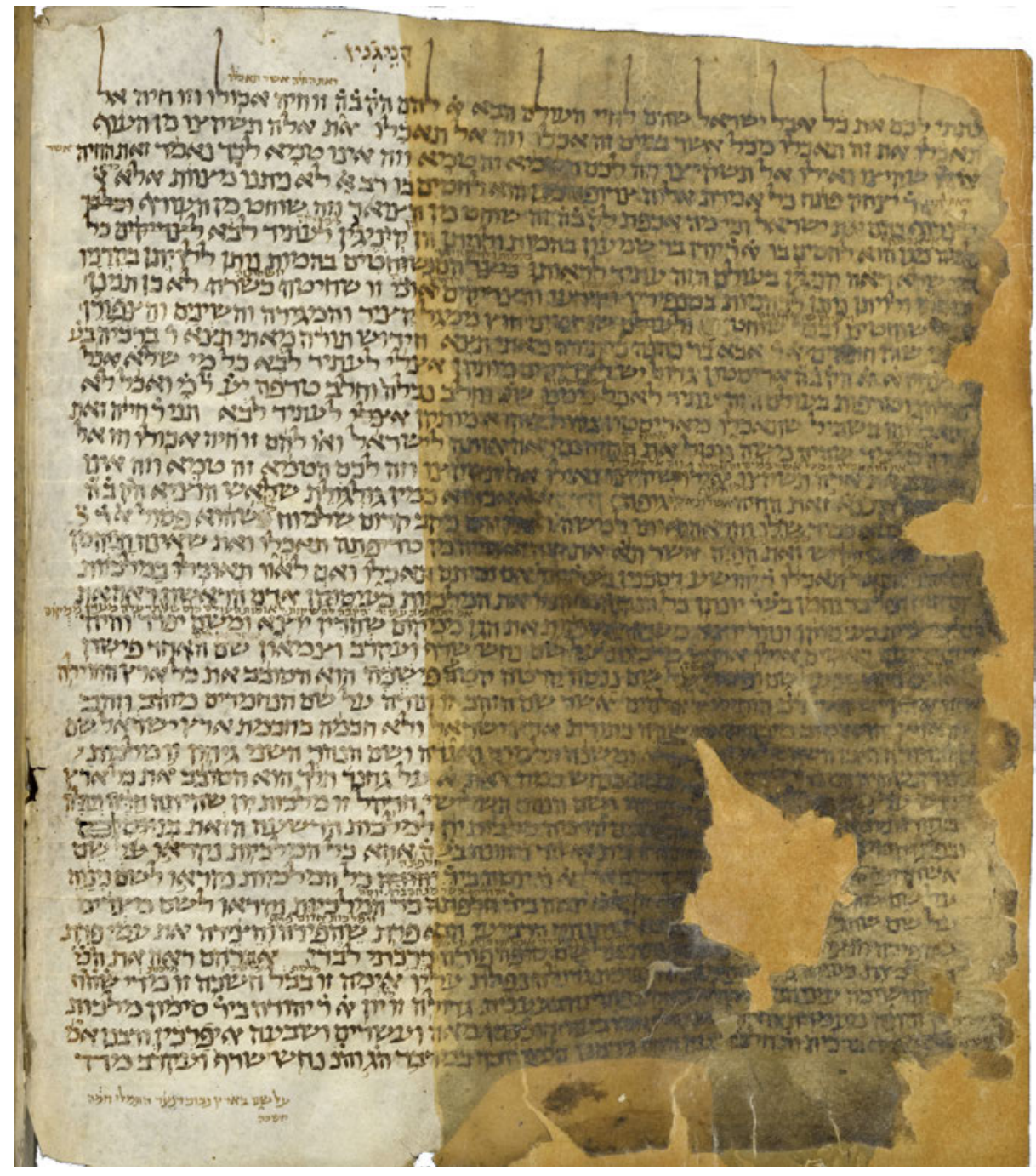

Fig. 7.6-2: Vayyiqra Rabba fragment, with extensive interlinear emendations, ninth-tenth-century hand. Source: Oxford, Bodleian Library, heb. c.18,17.

Subsequently, two of my colleagues at Bar Ilan University, Joseph Tabory and Arnon Atzmon, critically edited Midrash Esther Rabbah (Tabory and Atzmon 2014), also extensively following stemmatic principles. In addition, my ongoing research on the textual history of the early midrashic text Vayyiqra Rabba (see fig. 7.6-2) very much focuses upon stemmatic analysis to delineate the lines of filiation among the various textual witnesses. 


\section{Further reading}

From the above discussion, we can note that two related but distinct critical questions face the textual scholar of rabbinic literature. (i) Is it valid and proper to speak of an urtext with regard to the various compositions in the rabbinic corpus? (ii) What editorial methodology should be used to edit these compositions? The first question was debated in print by Schäfer (1986) and Milikowsky (1988), a debate revisited some twenty years later (Milikowsky and Schäfer 2010). Schäfer's conceptualisations form the theoretical underpinning of the work produced by his student Hans-Jürgen Becker (1999), which should be read with the review-essay by Milikowsky (2002). See also the somewhat similar perspective of Beit-Arié (2000), and Barth (1999). For the second question, there is a dearth of literature (in any language); most textual scholars in rabbinics barely touch upon the crucial methodological questions involved in producing a critical edition. See the relevant comments in Milikowsky (1996, 1999, 2006).

\subsection{Chinese}

Christopher Nugent

China has a continuous textual history that stretches back at least three thousand years; concerns with textual change over the course of both oral and written transmission appear in the early stages of that history. Confucius (551-479 BC) himself is portrayed in the Analects as lamenting lax editorial standards of his day, saying "I still recall when scribes would leave blanks in texts [...] today this is no more" (Analects 15.26). The dominant traditional interpretation of this line is that the Master believed scribes should not guess at the correct version of a missing or seemingly incorrect character when transcribing a text, but instead leave a blank. Numerous other texts from a few centuries later include examples of one character transforming into a completely different one over the course of multiple transcriptions, often with humorous results. Throughout this long history, scholars, and even ordinary readers, have developed a range of strategies for dealing with textual change that both overlap with and substantially diverge from those developed in Europe and elsewhere. Debates over textual criticism were often tied to contemporaneous political debates, in part because political arguments were typically grounded in specific readings of texts, classical texts in particular, but also because the scholars who undertook textual criticism as a specific pursuit were often powerful political actors themselves.

\subsubsection{Textual criticism in China}

The contemporary scholar William Boltz $(1995,394)$ has argued that, although Chinese textual critics have almost always sought to restore texts to some earlier state 
that they felt to be closer to the authors' original intentions, they typically saw textual change over time as an "inherent aspect of the life of the text itself", rather than a fundamental injury or defilement visited upon the text. Correcting a text was thus, in many contexts and periods, simply one of the tasks any serious reader would undertake as part of the full act of reading and understanding it. Boltz speculates that this attitude may have grown out of the nature of textual variation in the primarily logographic script used to write in China. Because all graphic variants are also potential lexical variants, they were not necessarily seen as errors; they were instead alternatives that the conscientious reader would always have to compare and judge for himself (Boltz 1995, 400).

There are a number of terms that have considerable overlap with the English "textual criticism" (though there are no traditional words for "stemmatology"). The earliest is choujiao 倠位校 (or jiaochou 校倠倠), which was traditionally interpreted as including two kinds of collation: analysing a text based on internal cohesion and consistency, and comparing a text with one or more other versions (Cherniack 1994, 82). The earliest explanation of this term dates back to Liu Xiang 劉向 (79-8 BC), to whom a variety of later texts attribute the statement: "When one person reads a text and comparing what is above and below finds an error, this is called jiao. When one person holds a text and another person reads it as enemies facing each other, this is called chou." Beginning in the Northern and Southern dynasties period (420589), the term jiaokan 校勘 began to be used for such scholarship and continues to be used as a general term up to the present. As Susan Cherniack notes, jiaokan (or the contemporary near-synonym jiaokan xue 校勘學) is typically taken to include not only collation, correction, and analysis of texts, but also banben xue 版本學 (the study of the physical characteristics and history of editions) and mulu xue 目錄學 (the study of bibliographical catalogues and classifications; Cherniack 1994, 82). The first full monograph on collation dates to the twelfth century AD. As described by modern scholars beginning with Chen Yuan (1880-1971), traditional collation practices with both single and multiple exemplars took four basic forms: (i) comparison of multiple editions to note differences, (ii) examining a single text to identify internal discrepancies, (iii) comparing a text with other sources on similar subjects, and (iv) using one's own judgment to correct perceived textual problems in a single witness (summed up in Cherniack 1994, 85; see also Cheng and Xu 1998).

Versions of all of these practices have been in use for over two thousand years in China. Covering such a vast span of time and texts in a brief account is nearimpossible, and this contribution can only identify and explicate a few key issues and important stages in the evolution of Chinese textual criticism. After a brief account of material matters, I will discuss three historical periods in which crucial changes in textual practices took place. 


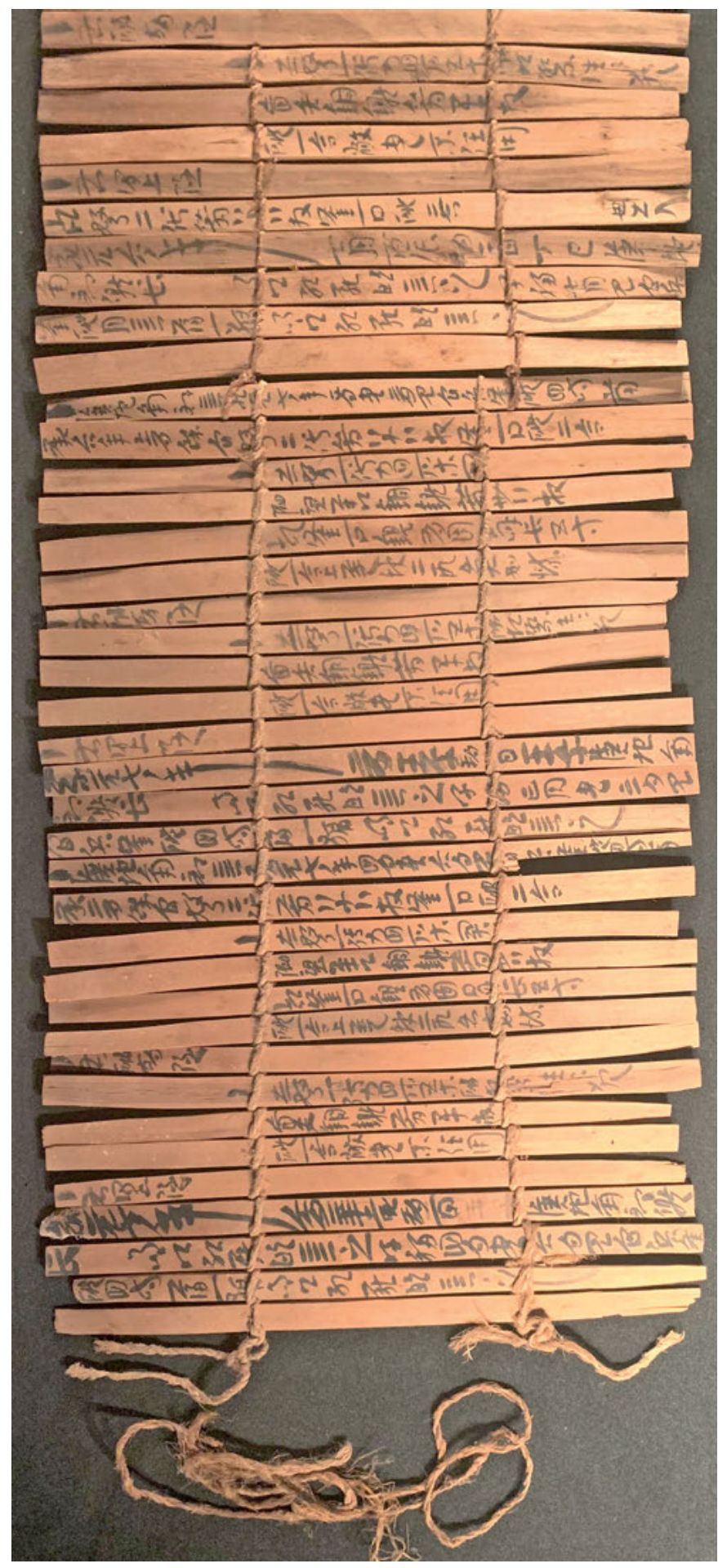

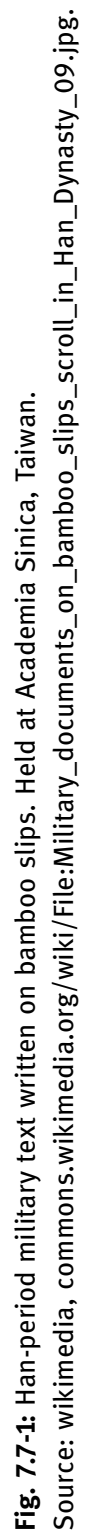




\subsubsection{Textual media}

The earliest surviving writing from China is found inscribed on cattle scapula and tortoise plastrons used primarily for divinatory practices by the royal court of the Shang 商 dynasty (ca. 1300-1046 BC). The written texts on these objects (known in English as oracle bones), which began to be discovered and recognised as written text only at the end of the nineteenth century, do not appear to have been transmitted or to have entered the historical textual record, and thus do not directly concern us here. The earliest surviving texts that are considered part of the literary tradition are found on vessels and other objects (such as weapons) cast in bronze during the Western Zhou 周 period (ca. 1045-771 BC). Many of these texts did enter the tradition and were later circulated in a range of formats. Bronzes were ritualistic objects, not a medium for the initial composition of texts or for more quotidian writing, which would have been done on more perishable surfaces, such as bamboo. Although direct archaeological evidence dates only to the end of the Warring States period 战国时代 (481-221 BC), both oracle-bone texts and bronzes include a word that appears to refer to strips of prepared bamboo, bound together by a string (most likely of either leather or hemp): ce 冊 (Boltz 1999, 107-108). Finds from Warring-Statesperiod tombs indicate that such bamboo strips (and, less frequently, strips of other kinds of wood) were the primary textual medium of the time, one that many argue is the source of China's traditional vertical textual format. Silk was used for writing in some contexts, but the significant expense it entailed limited such use. Finds from the Warring States have also yielded the earliest examples of hair-tipped brushes, though traces of ink on other objects give indications that brushes were used for writing as early as the Shang and for precursors of writing centuries earlier. They would continue to be the primary writing tool, with ink based on lampblack or pine soot, until well into the twentieth century.

It is important to keep in mind that memorisation and oral recitation also played a primary role in textual transmission as late as the Western Han 漢 (206 BC$8 \mathrm{AD}$ ), if not later. This was due in part to traditional modes of instruction and in part to the limitations of the physical media. Bamboo strips were inexpensive and relatively easy to prepare for writing, but they were bulky and difficult to transport in large quantities. It is thus unlikely that full written versions of longer works regularly circulated as full texts as opposed to excerpts and individual chapters. Ownership of physical texts was likely quite limited, even among the elite. Moreover, excavated texts from the pre-Han period in particular demonstrate substantial graphic variation while often maintaining a high degree of lexical stability. This is a strong indication of memorisation and oral transmission: works were set to memory as sounds, but a range of different graphs could still be used to represent those sounds in writing (Kern 2002, 2010). Standardisation of the writing system would be a later development (see further discussion of these particular aspects of the written script below). 


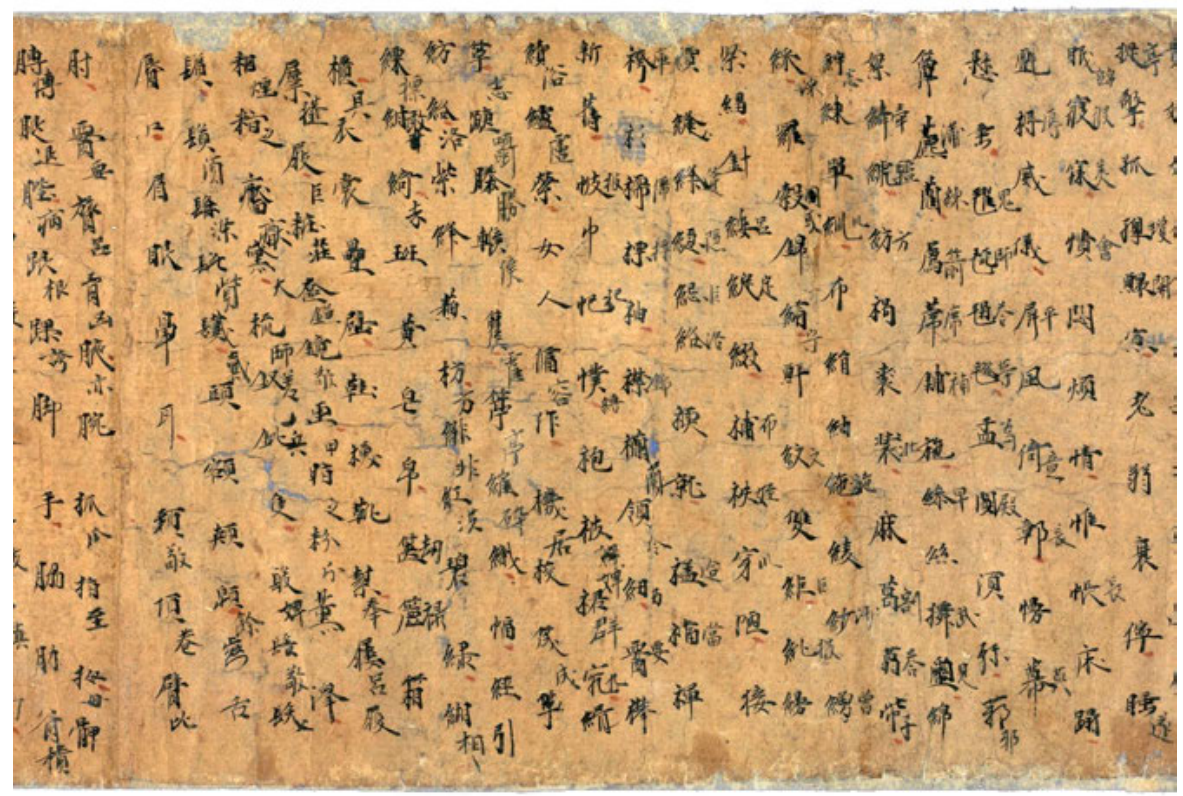

Fig. 7.7-2: Tenth-century AD paper manuscript from Dunhuang, China, containing the vocabulary primer Kaimeng yaoxun 开蒙要训 [Important Instructions for Beginners]. Source: Gallica, Bibliothèque nationale de France, gallica.bnf.fr/ark:/12148/btv1b8302088s/f2.image.

The dominant textual media for most of Chinese history has been paper, a material for which the earliest examples, excavated from tombs, date back to the early years of the second century BC (Tsien 2004, 146-147). These examples included limited writing, such as the name of the medicine the paper was presumably wrapped around, and even a drawn map, though there are no indications that paper was used for more extensive writing at that point. Refinements in quality resulted in a paper more suitable for writing by the second century $\mathrm{AD}$, and by a century later it was likely the most common textual medium, though bamboo continued to be used, especially in more isolated regions. The development of xylographic printing began in the Tang 唐 dynasty (618-907), and was used by both the state and religious organisations by the end of that period. By the end of the eleventh century, there was a flourishing printing industry that would grow substantially in later centuries.

The widespread use of paper made textual production and reproduction more inexpensive than it had ever been. An educated person in the Tang would likely have owned hundreds of scrolls (the primary format of written texts before printing). Printing made large-scale reproduction much more efficient, with the result that the amount of written material and its accessibility increased rapidly and dramatically. At the same time, manuscripts continued to be used in a range of contexts. At one end of the economic spectrum, a fine manuscript would continue to be valued more than a fine printing for many centuries. At the other, copying out 


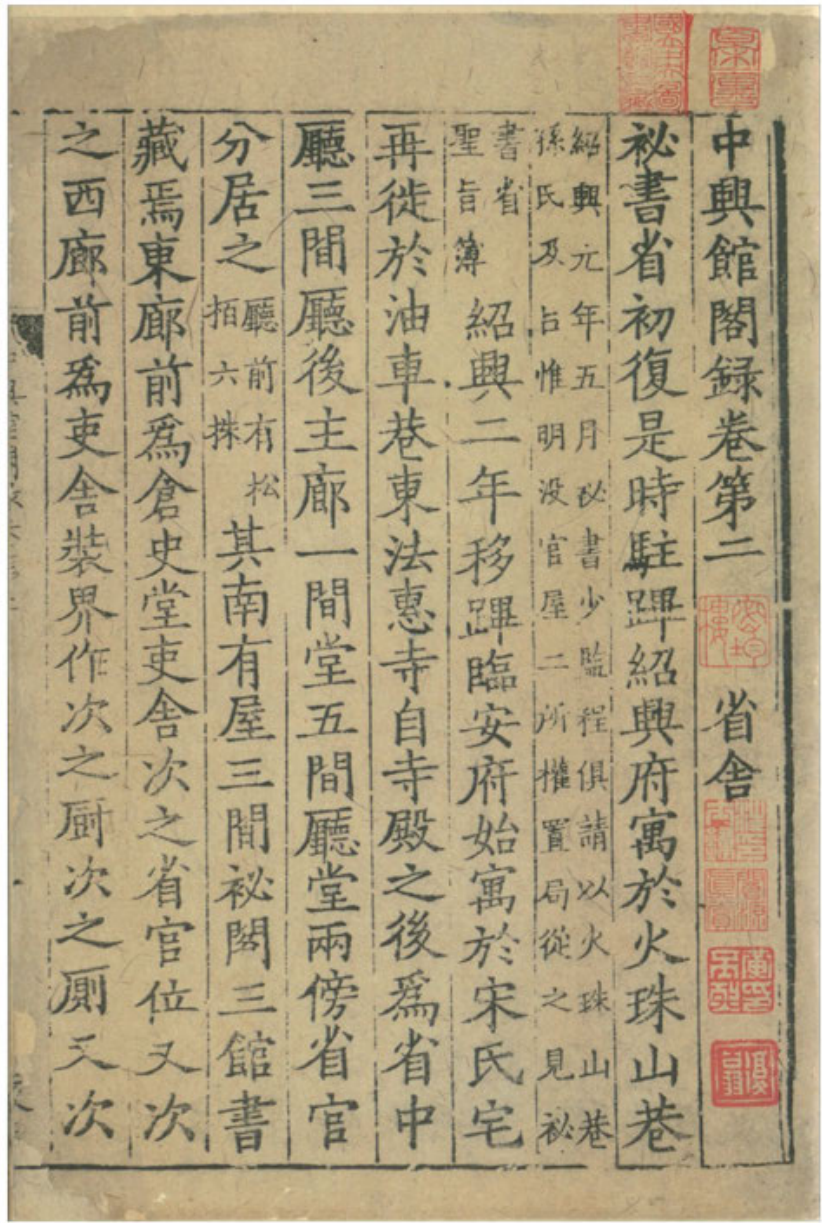

Fig. 7.7-3: Thirteenth-century AD paper woodblock print of an account of the Song dynasty imperial library. Held at the National Central Library, Taiwan. Source: wikimedia, commons.wikimedia.org/ wiki/File:Records_of_the_Southern_Song_Imperial_Library_WDL7099.jpg.

books by hand was still often cheaper than buying a printed edition (and was also seen as an effective way to learn their contents). This textual abundance, however, did not fully eclipse the lively oral and memory-based aspects of literary culture. Poetry, in particular, remained an intensely oral endeavour, even though its products were frequently set down in writing. Texts would often be copied out from memory, and even printed texts would be recited and memorised (though by the thirteenth century, important thinkers had begun to lament that printing had resulted in a more superficial relationship with classical texts, as the wide accessibility of written material made memorisation a choice rather than a necessity; Gardner 1990, 139). 
While all these media have contributed to textual survival, they have done so in different ways. Widespread memorisation and recitation of certain texts allowed them to survive times of large-scale social disruption, whether from the violence of war or from natural disasters, and the destruction of such material textual depositories as imperial libraries or private collections that inevitably resulted. Many texts inscribed on bronze vessels survived unchanged over centuries or even millennia, though they most often did so in the solitude of the tomb, unseen by human eyes. Paper has always been a fragile medium, susceptible to fire, water, insects, and simple neglect. Yet because it is light and inexpensive to produce, it allowed rapid and wide-ranging textual transmission on an unprecedented scale, with the constant textual alteration that always accompanied it. Printing meant that multiple copies of written works were far easier to produce and obtain, but rapid (and often careless) production massively increased textual instability.

\subsubsection{Textual collation and creation in the Han}

The first key period in the history of textual criticism is the later years of the Western Han, especially in the last part of the first century BC. The Han faced a chaotic textual inheritance: natural disasters and the widespread warfare that accompanied the fall of the Qin government in 221 resulted in massive textual loss and dispersal, as government archives were burned and personal libraries, such as there were, faced similarly dire fates. Recent scholarship has suggested that the infamous Qin bibliocaust, in which the First Emperor is said to have demanded the confiscation and burning of all books (and the scholars who taught them) that did not accord with his favoured political philosophy, is likely more an invention of Han-period historians anxious to establish the relative virtue of their own dynasty in comparison to their predecessor than an accurate account of events; yet there is no question that the years of chaos took their toll on the written word.

In 26 BC, Emperor Cheng 成帝 (r. 32-7 BC) assigned his Palace Superintendent, Liu Xiang, the task of organising and categorising the chaotic mass of bamboo scrolls (and, no doubt, scattered unbound strips) contained in the imperial library. He was, additionally, to fill any important gaps that he perceived in the collection by gathering texts, whether in written or oral form, wherever he could find them. Liu Xiang and his staff transformed these scattered materials into separate texts for which, in each case, they eventually provided a detailed account of the content, information about the author, descriptions of the sources, an account of the collation process, and a general discussion of the text. Liu Xiang himself combined and edited these accounts into a catalogue entitled Divisional Records (Bielu 別錄). After his death, his son, Liu Xin 劉㰴 (d. $23 \mathrm{AD}$ ), continued the father's work and produced a further summarised version known as the Seven Summaries (Qilüe 七略).

The Lius and their staff thus undertook China's first great bibliographical project, and in fulfilling their charge they went far beyond simple collection, organi- 
sation, and description. It was, in fact, a full-scale transformation of the textual inheritance into something that, while carefully organised, in many ways bore little resemblance to the textual environment that preceded it. This transformation operated on multiple levels. In terms of script, Liu and his colleagues transcribed all of the materials, which had previously been in a diverse set of regional and archaic scripts, into the more standardised script then current at the Han court. In the process of transcription, they also radically reorganised their material, bringing together textual portions that may have originally circulated separately and changing the structure and order even of texts that were received in a seemingly more coherent form. They heavily redacted works as they organised them, excising often substantial amounts of text that they judged to be redundant. In some cases, as much as $90 \%$ of the original material was discarded in the name of bringing organisation and coherence to a text, with smaller-scale redactions being common (Nylan 2014).

This process was intended to turn disparate materials into organised "books"; yet, as a number of scholars have recently argued, when we have excavated nearcounterparts to the received works that passed through Liu's process, the received text often reads more awkwardly and seems more disjointed than its excavated counterpart (Kern 2010; Richter 2013; D. Meyer 2012). As Martin Kern has written, "Liu Xiang's editorial choices were meaningful and appropriate to the imperial environment of official learning but not necessarily the best reconstructions of ancient texts that originally functioned in a very different cultural context” (Kern 2010, 63). That "different cultural context" was a more intensely oral one, in which written texts would typically be used in conjunction with the oral instruction and argumentation that played an important part in conveying the texts' meanings (D. Meyer 2012). Such texts would often include structures that emphasised mnemonic efficiencies no longer deemed necessary or appropriate when the texts were transcribed in an archival context.

In short, the imperial bibliographical project created standardised versions of texts that differed sufficiently from their precursor material to justify considering them to be new works. They were given new organisational structures and scripts that distanced them from their original context. They were given authors where previously they had none. Liu Xiang and his staff were clearly engaged in an early form of textual criticism (and indeed, the four main categories described in the introduction above can likely be traced back to them), but their work also often obscured the textual past as it created the texts that would be the focus of centuries of scholars who followed.

\subsubsection{Transitions to print}

Some thousand years after the Lius completed their work for the Han imperial library, textual criticism in China entered a new stage with the increasingly wide- 
spread use of xylographic printing and the gradual shift from a manuscript culture to one in which print played a more dominant role. Needless to say, the millennium between these periods saw many important changes and innovations as well, from the spread of paper as the primary writing medium to new scholarly work on classical texts, but the impact of printing stands alone.

There are striking similarities here with the late Western Han. As in that earlier period, readers and bibliographers in the early Song 宋 (960-1279) faced a fragmented and confused textual situation due to the chaos of rebellions and war that brought about and followed the end of the preceding dynasty. Paper was, if anything, more fragile than bamboo, and the large-scale destruction of the holdings of imperial, private, and religious interests took a massive toll. Stephen Owen uses the evocative term "flotsam and jetsam" to describe what survived, noting that it refers, appropriately, to the remains of a shipwreck (Owen 2007, 296; see also Barenghi 2014). Like Emperor Cheng, the first Song emperors sought to restore the imperial collection from those remains, building from a limited base of 12,000 scrolls in the early years of the dynasty to reach over 46,000 just few years later; these additions came from a range of sources, including surviving collections of provincial and regional libraries and private collections (Dudbridge 2000, 2).

Perhaps the most important aspect of bibliography and textual criticism in the Song was the extent to which it was carried out not only by the government but by private individuals as well. The larger project of textual criticism had become far more diffuse than it was in the Han. Different actors had overlapping but often divergent goals for the work they did. The government sought to create model texts, especially of the classics, that could serve as the basis of everything from the exam system to imperial proclamations. As Cherniack argues, "the [governmental] editor's job was to present the single correct text, selected from a set of mistaken alternatives. To record and weigh the excluded alternatives in the form of scholarly annotations was irrelevant and even contrary to this purpose" $(1994,72)$.

Private scholars, on the other hand, would often emphasise the differing alternatives presented by multiple exemplars. This would allow them to put their own scholarly process on display and thus demonstrate their erudition in order to establish their authority (Cherniack 1994, 72). Again, even as central governments sought to establish model texts, individual readers had always seen correction and collation as one of the basic duties of any good reader. It was never the sole purview of specialists, and would not be until well into the modern period. Of course, scholars often lamented that those of lesser abilities ruined texts in the process because of their lack of sufficient learning, but they accepted that readers would take a critical attitude towards texts.

Printing was clearly not the sole cause of widespread awareness of textual variability, but it was an important one. The likelihood that an individual reader would encounter multiple editions of the same text increased dramatically with the spread of print, and many of the most famous writers in the Song describe collating differ- 
ent editions of texts for both edification and entertainment. Indeed, though printing is often described as having a stabilising effect on texts by "fixing" them, Song readers were well aware that this was not necessarily the case. Printing instead seemed to cause a massive proliferation of textual variation that required constant correction and collation to manage.

In addition to being influenced by increasing awareness of textual variation due to printing, textual criticism in the Song was connected to a scholarly orientation that encouraged a sceptical attitude towards large portions of the literary inheritance, including the texts of the classics. In a very broad sense, this grew out of philosophical notions that emphasised the ability of an individual to personally grasp the underlying patterns and order of all things in the universe, from the natural world to the moral and textual one. Song work on texts thus often focused not on hard textual, linguistic, and historical evidence, but rather on the individual reader's own grasp of fundamental truths that allowed him to understand what any given text should say and correct it to bring it in line with that deeper meaning if it appeared to have diverged from it. This was still an act of restoration, but it was a deeply subjective one (albeit undergirded by the belief that all sufficiently cultivated subjectivities will, as they are grounded in objective orders, come to the same conclusions), and would later come under intense criticism for this very quality.

Because of their long-standing cultural and institutional importance, the texts of the classics remained relatively stable through the transition to print during the Song. They were never at risk of falling out of circulation during the chaos at the end of the Tang. The same cannot be said of the vast quantities of literature produced during that latter period. Tang poetry, widely regarded as a high point of literary production in China, comes to us only through the very selective filter of what survived into the Song and what Song printers chose to print. As Stephen Owen and others have demonstrated, different collections that circulated during the Tang provide vastly different impressions of the output of individual poets. Only a very small subset of those collections made it into the Song and were reproduced in print, meaning that our understanding of any given poet is likely based on only a small portion of his works. The judgements of his contemporaries might have been quite different, being based on different material. Song collectors and editors shaped our own understanding of Tang literature in ways we are only beginning to fully understand (Owen 2007).

\subsubsection{Evidence-based textual criticism in the Qing and later}

Scholars in the Qing period 清 (1644-1911) shared their Song predecessors' sceptical orientation towards the received textual tradition. However, they believed that a significant portion of the problems with received texts could be traced to the sloppy emendations introduced by those very Song scholars and readers on the basis of 
their philosophical ideas. Qing textual critics famously turned away from philosophy as the foundation for their work, grounding it instead on rigorous evidencebased philology. The new orientation of textual scholarship became broadly labelled with the term kaozheng 考證 (evidential research). The term itself had been used in the later part of the Song period, but it gained new prominence and importance in the Qing as a way to describe a focus on verifiable evidence rather than philosophical speculation. The factors that led to this shift in orientation were many, ranging from the increasing interest in book collecting by literati in the preceding Ming 明 period (1368-1644) to new exposure to scientific ideas from the West (Elman 1985, 143).

Kaozheng scholarship was characterised by a focus on phonology and palaeography as the most effective ways to restore the texts of the classics to what they must have been in the time of their initial creation. Although their critiques of earlier scholarship were multifaceted, kaozheng scholars took particular issue with the basis of Song scholars' methodology and their lack of understanding of historical phonological shifts. Song-period textual criticism, they argued, was rarely based on observable evidence but instead grew out of much vaguer philosophical notions. Moreover, because these philosophical ideas had been heavily influenced by Buddhism and Daoism, the textual alterations based on them inevitably pulled texts away from their proper Confucian origins.

In terms of phonological issues, earlier readers had long observed that classical texts rhymed (or failed to rhyme) in unexpected ways. Their solution was sometimes to alter the texts so as to bring them in line with their expectations (Elman 1985, 213). Due to their meticulous research into phonology and etymology, kaozheng-based textual critics understood that these unexpected rhyming schemes were often the result of changes in pronunciation of the characters over the centuries since the classics were composed, rather than later mistakes that had crept into the texts. The later emendations to "force" the rhyme were thus themselves errors that the Qing textual critic would have to correct in order to return the texts to their original state.

Contemporary textual criticism as conducted in both China and elsewhere (especially Japan, Korea, Europe, and the United States) is diverse, but much of it ultimately grows out of earlier practices, especially the methodological advances made by kaozheng scholars. The vast majority of pre-Song-period works come to us through the received tradition consisting of printed texts. Collation of those texts, especially as practised by scholars producing critical editions for major academic presses in China, typically follows some combination of the long-standing methods described in the introductory section above, with particular emphasis on comparing multiple editions. In many cases, the earliest exemplar will be a Song imprint, but there are also numerous examples where our earliest exemplar dates from much later.

Recent decades have seen exciting new scholarship on excavated texts as the pace of archaeological discoveries in China has increased. These fall into two major 
groups: manuscripts on paper dating to approximately 400-1000 AD discovered in and around the oasis town of Dunhuang in Gansu province at the end of the nineteenth century; and documents on bamboo, silk, wood, and other materials dating to the Han and earlier that have been unearthed more recently. These very different sets of documents have been the subject of a range of scholarly approaches. The Dunhuang manuscripts consist primarily of previously known Buddhist works, although other types of writings found there are strikingly diverse in terms of genre, language, and degree of representation in the received tradition. When creating a critical text of works with multiple exemplars from Dunhuang but not part of the received tradition, scholars in China will often use a version of the Bédier "best-text" method, though they typically make more changes to their "best text" than one would expect. The situation with Han and pre-Han excavated texts is more complex. Because of the massive bibliographical project undertaken in the Han described above, even excavated texts that appear to have counterparts transmitted by copying differ from those later collations dramatically. Indeed, it is these discoveries that have revealed the extent of the impact of Liu Xiang's work. Some scholars in the West, such as Boltz (1995), have utilised a Lachmannian stemmatological approach to create an assumed semblance of an "original” text. Others, such as Kern (2002), have criticised such an approach, arguing that lengthy periods of oral and mixed oral/written transmission make attempts to create a true "original" misguided.

Regardless of the particular approach, recent theoretical and practical work on mediaeval European manuscript culture has been particularly influential for scholars working in the West (Boltz, Tian, Kern, Owen, Nugent, Richter, Meyer). The combination of traditional Chinese approaches and newer theoretical ideas coming from scholars working on European traditions looks to be a fruitful one, and many new avenues of scholarly exchange are sure to open up in coming years.

\section{Further reading}

Readers interested in exploring textual issues in the early and pre-imperial period would gain much from Kern (2002). For a fuller treatment, Richter (2013) is excellent as well. For the Song period, Lianbin Dai (2016) looks closely at the important case of Zhu Xi. For the Qing period, Sela's new work (2018) is recommended. For those who can read Chinese, see Hu (1931), Wang (1972), and Guan (2013).

\subsection{Early modern printed texts}

Iolanda Ventura

This section deals with examples of methodologies used when editing Renaissance printed works from the nineteenth to the twenty-first centuries (see 1.4 for an assess- 
ment of the technical and cultural revolution induced by the introduction of the printing press). These works can be divided into two main categories: works that circulated directly in printed form (and for which no manuscripts survive) and works preserved both as manuscripts and printed copies. Types of modern editions (see 6.1) include facsimile editions (7.8.1), diplomatic or critical editions based on one single printed copy or on several (7.8.2), and critical editions based on both printed books and manuscripts (7.8.3).

\subsubsection{New life for old celebrities: The facsimile edition}

A facsimile edition is an exact photostatic reproduction of one copy of a printed work. In contrast to a diplomatic edition (see 6.1.3), it does not offer a faithful and accurate transcription of the text but reproduces visually all external features of the text. Several reasons may be advanced to justify the choice of this technique. A first, obvious one is if the length of a work would make the transcription too long to complete in a reasonable amount of time (the possibility of OCRing early printed books, albeit not yet perfectly, will change this situation considerably). A second, no less important reason can be found ex negativo in the lack of interest in reproducing a text that is already clear and correct in its printed form (although an image of a text is, of course, less usable than a transcription).

The main contribution offered by the editor consists of an introduction providing readers with basic information about the author, the edited work, and its characteristics, and about the role it played in the history of the literary genres to which it belongs and/or in the history of its contemporary culture. The most important functions performed by facsimile editions are as follows. ( $i$ ) They put works that are necessary for research at the disposal of scholars in a form closer to what could be accessed when those works were created and used. (ii) They compensate, although incompletely, for the lack of a critical edition, which may never be published. This is the case, for instance, with Avicenna's Liber canonis in the Latin translation made by Gerard of Cremona around 1150, which is still used and quoted, if not with the help of the printed versions scholars can find in a library, then according to the facsimile edition printed in Brussels in 1971 (Avicenna 1527, repr. 1971). This reprint presents the Latin version as published in a 1527 edition, which had corrections and improvements by one of the most illustrious Renaissance Arabists, Andrea Alpago (on Alpago, see Levi dalla Vida 1960). (iii) They allow readers to consult a precious old printed copy displaying relatively sophisticated production techniques. This is the case, for example, with Hartmann Schedel's Chronik. This universal chronicle, authored by the famous Nuremberg physician, humanist, and book collector Hartmann Schedel (1440-1514), was published in 1493 by Anton Koberger both in Latin and German. It was accompanied by a lavish corpus of illustrations consisting of some 1,800 coloured xylographs, which makes the work extremely valuable for ex- 
perts both in the history of humanist historiography and of book illustration. The work was published as a facsimile in 2001 (Schedel 2001), in a version that reproduces the work and the illustrations exactly and can therefore be used as a substitute for the precious original.

Digital facsimile editions have now enhanced the accessibility of these early printed books. They are made available either in the framework of digitisation programmes for both manuscripts and early printed works run by single libraries, such as the Bayerische Staatsbibliothek, the Biblioteca Apostolica Vaticana, the Bibliothèque nationale de France, or the British Library, or in the framework of research projects that combine the study of a work or a group of works with the availability of digital editions on the Web. Digital reproductions offer several advantages compared to non-digital facsimile editions: (i) several printed copies of the same work can be displayed at the same time, allowing a comparison of form and content; (ii) digital facsimiles are searchable via library catalogues or search engines; (iii) most of them are accessible for free, whereas non-digital facsimiles are very expensive; and (iv) further material and tools for accessing, analysing, and understanding the work can be added. Among numerous projects, we can mention the website Welt und Wissen auf der Bühne: Theatrum-Literatur der Frühen Neuzeit (theatra.de), which allows the reader to access and download for free some two hundred works that use the metaphor of the theatre or of the garden as a model to represent encyclopedic knowledge, and to study them with the help of a large body of literature (albeit not updated since 2012).

\subsubsection{Old wine in new barrels: Modern editions of Renaissance printed works}

Renaissance works preserved only in print may differ greatly with respect to their connection to the author's original, to the number of editions, and, last but not least, to the versions of the text that were published. If, to name but one example, Johann Heinrich Alsted's Encyclopaedia in septem tomos divisa was printed only once in 1630 (Alsted 1989-1990), other works were printed several times, sometimes after being revised by their authors. Erasmus of Rotterdam's Adagia, for example, was printed thirteen times between 1508 (editio princeps, Venice: Aldus Manutius) and 1536 (Basle edition, printed by Hieronymus Frobenius). If, in the case of Alsted, a facsimile of the sole existing printed copy may suffice, in the case of Erasmus' bestseller or other relatively unstable texts, other editorial strategies will be called for.

When dealing with several different printed copies of the same early modern work, editors will need to select and collate these different copies, and to prepare an edition according to one or more printed witnesses. There are, again, several possibilities for an edition. (i) If based on one single printed copy, the edition corresponds, mutatis mutandis, to the monotypic edition of a codex unicus (see 6.1.3).

(ii) The editor may use one printed copy as a base text, using one or more other 
printed copies to correct and improve the quality of the text, and including their variant readings in a critical apparatus. This corresponds to a best-manuscript edition (see 6.1.3). (iii) Several, if not all, printed copies may be collated to produce a critical (reconstructive) edition (see 6.1.2).

All types of editions aim at facilitating the consultation and use of these early modern works by contemporary readers. Consequently, in the editions, a normalised orthography will usually be adopted, abbreviations will be expanded, punctuation (4.3.4) will be adapted, and the text will often be translated into a modern language. Commentaries and apparatuses of sources are valuable features of these editions, allowing the reconstruction of the author's library and of his authorities and references. All these elements represent a decisive step forwards compared to a mere facsimile edition, and provide a more reliable basis for the study of an author's culture. On the other hand, editorial emendations or conjectures (see 6.2.3) are reduced to a minimum and are basically meant to correct obvious misprints. As for the criteria used for the reconstruction of the text, they are relatively different from those used in editing texts preserved in manuscripts, as the paths of transmission of printed copies are obviously very different for several reasons. First of all, the author's work did not undergo a long process of changes and deterioration due to manual copying. His final original text is easier to detect, especially if the editio princeps was published during his lifetime or even under his supervision. Even if the author reworked his text and published it again, the collation of the different versions does not have to wrestle with variant readings caused by later, non-authorial innovations, but only with deliberate changes that are valuable for research and have to be documented and highlighted. This generally leads to a reduced number, and less problematic nature, of variant readings, and to a general tendency towards philological work that is descriptive rather than invasive.

Furthermore, if we do not have to struggle with authorial versions, the texts we deal with are more stable and, as soon as they reach a fixed form, obtain an authoritative status. As a consequence of this, if the text does not contain evident misprints, it is not necessary to correct it. It is also normally possible to detect easily the (mostly chronological) connections between the different printed copies, and our evidence is rarely lacunose (only rarely is a complete set of printed copies lost in its entirety), and the editio princeps acquires a central position around which later printed copies are clustered.

A practical consequence of this stability of the tradition and centrality of the oldest printed edition is the small size of the critical apparatus. Generally speaking, the apparatus is only used to record variant readings shown by other printed editions, or to record the presence of marginalia. In fact, editions relying on a single printed copy without being a facsimile are quite rare. One important exception is represented by the two modern editions of the 1543 print (published in Basle by Johann Oporinus) of Vesalius' De humani corporis fabrica, each with a French translation. The first modern edition was published completely in the print medium 


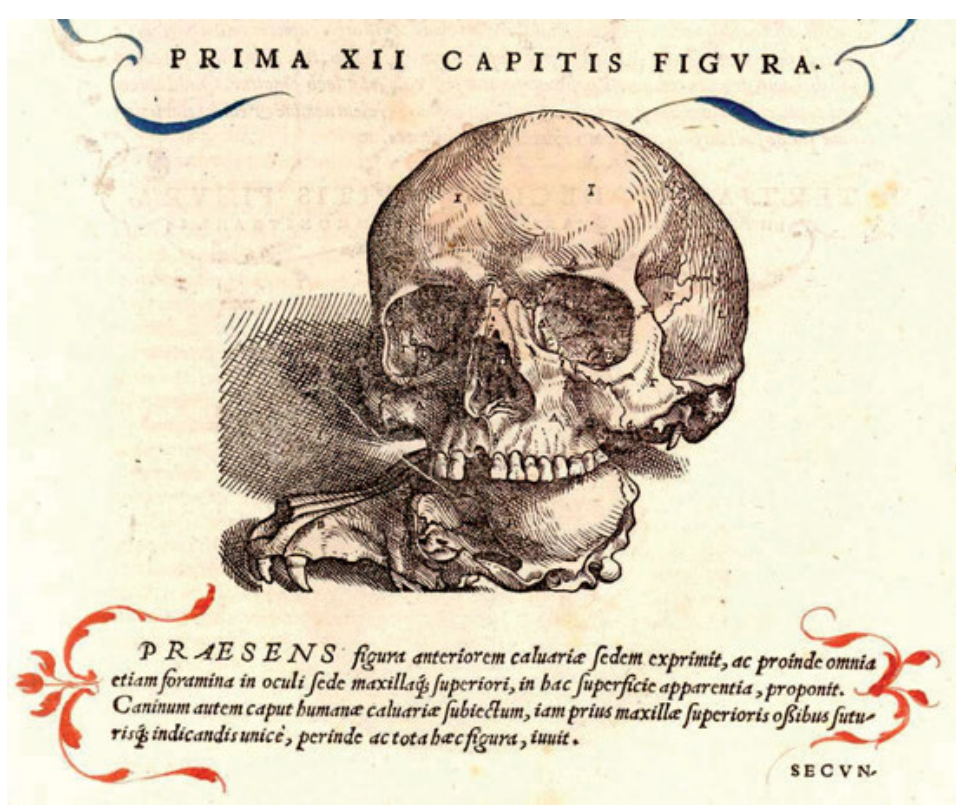

Fig. 7.8-1: Anatomical illustration from Vesalius $(1543,47)$.

(Bakelants 1961); the second modern edition is still ongoing as an online project (www3.biusante.parisdescartes.fr/vesale/debut.htm). The reason for ignoring the second, updated, print edition of the Fabrica published in 1555 by the same Johann Oporinus, and for concentrating on the editio princeps, is that the 1543 edition has attracted more attention because of the revolutionary character of its anatomical illustrations (see fig. 7.8-1), even though the 1555 edition is more advanced from an epistemological and scientific perspective.

The majority of the editions based on several printed copies take as a starting point either the entire printed tradition or a relevant part of it, and use them to provide a complete overview of the transmission and a critical text. Usually, the evidence used by editors consists of the editio princeps in combination either with a wide chronological range of secondary printed copies, or with those that are chronologically close to the editio princeps or relevant for scholarship. Normally, editiones descriptae, that is, printed copies that, after a precise examination, turn out to be pure reprints of a previous print, are left aside. As for the establishment of the text, the general rule is to select either the editio princeps or the last edition supervised by the author as a base text, and to use the others to correct the first one, or, more often, just to record the differences, possible errors, and innovations featured in them. These general principles can be adapted to the specific situation of the edited text. The following three examples are ordered in an increasing level of complexity. 


\subsubsection{1 lacopo Zabarella, De virtutibus naturalibus}

A first, linear, example of a new edition of a printed work following the principles I have just listed, and taking into account some necessary adaptations, can be found in the recent publication of Iacopo Zabarella's (1532-1589) De virtutibus naturalibus (Valverde 2016: for the editorial criteria, see 1:46-48). The editor, Juan Valverde, relied on the two independent copies printed in the same year (1590) in Venice (by Paolo Meietti) and in Cologne (by Giovanni Battista Ciotti). He collated them against the edition which had been the most famous up to that point, namely the one published in Frankfurt by Lazarus Zetzner in 1607, which scholars had long used thanks to a facsimile reprint (see 7.8.1) issued in Frankfurt in 1966; the facsimile should not be discarded, but nevertheless needed to be improved on.

As for the decision to collate the two earliest printed copies, the editor's choice is motivated by the fact that, whereas the Venetian print is closer to the author and its text is more correct, the Cologne edition features some elements that cannot be neglected when we attempt to understand the development of the text in print. The two editions resulted from two independent projects, and their opening sections show significant differences: the Cologne edition includes a dedicatory letter addressed by Zabarella to Pope Sixtus V, whereas the Venetian edition includes a prologue by the author that had already been published in his De naturalis scientiae constitutione (Zabarella 1586, printed in Venice by Paolo Meietti). The Cologne edition contains the same mistakes that are found in the text of the Venetian one, but has been emended in a list of errata published as a separate sheet in the Venetian print. All in all, we can conclude that the Venetian and the Cologne prints were based on the same urtext but developed differently. As for the Frankfurt edition, the modern editor notes that it keeps almost all errors that were corrected in the Venetian errata list but at the same time introduces some others.

From the approach followed by the editor, we can conclude that he selected his material by considering two editiones principes exhibiting substantial differences but nonetheless possibly relying on the same urtext, and chose to follow the more correct text; and that he did not dismiss an edition that might now be considered superfluous but nonetheless deserves attention because it was - in a well-known facsimile - the basis on which scholarship had relied for several decades.

\subsubsection{Erasmus, Opera omnia}

The project of a critical edition of Desiderius Erasmus' (1466-1536) Opera omnia began in the early sixties, and has been run by the Dutch Royal Academy for Sciences and Arts since its inception (description on huygens.knaw.nl/erasmi-operaomnia/?lang=en; see also brill.com/view/serial/ASD). Following Erasmus' choices, as well as the structure of the editions published in Basle between 1538 and 1540 and in Leiden between 1703 and 1706, the arrangement of the edition reproduces the canon (ordo) that divides his ouvre into nine classes dealing respectively with 
(i) philology and pedagogy; (ii) proverbs (the Adagia); (iii) correspondence; (iv) morals and ethics; ( $v$ ) religious instruction; ( $v i$ ) the Greek text, annotations, and Latin translation of the New Testament; (vii) paraphrases of the New Testament; (viii) editions of or commentaries on patristic authors; and (ix) apologiae. According to the guidelines included in the general introduction in Erasmus (1969), the modern edition is to furnish a critical text based on prints and taking into account, whenever available, manuscripts. However, pre-eminence will be given, still according to the guidelines, to "the first edition authorized by Erasmus [which] will be the basis for the establishment of the text" (xviii); variant readings attested in "authoritative" editions will be recorded, whereas those derived from "reprints published without Erasmus' knowledge" will be left out (xix-xx). Each print is to determine the orthography chosen for the edition, thus explaining the eventual inconsistencies. All in all, the general plan acknowledges Erasmus' authority and control over the editions he could supervise. On the other hand, this plan does not intend to reduce the editorial work to the choice of one, fixed, stable edition for all works, nor to focus on the one print that constitutes the basis for the edition of each work. Rather, the goal of the editorial choices is to reconstruct in the edition the path followed by the writings before reaching a definitive printed form, and to show changes and updates made by Erasmus while reworking them. This concept of an evolutive edition, which places manuscripts and editions in a flow reflecting both Erasmus' activity and the circulation of the texts before and after the appearance of the authorised versions, leads to some important consequences. (i) In principle, even when the Basle editio princeps of the Opera omnia plays an important role, the stages of development that preceded it have to be taken into account, if not in the edited text, then at least in the introduction to the work. (ii) The same goes for each authorised version selected as the basis for the edition, which implies that, although it remains the basis, earlier stages of the work cannot be neglected. (iii) If an earlier version is preserved, entirely or in part, that clearly differs from the one represented in the printed editions, it is included in the edition, albeit in a separate place. For example, the first redaction of the Antibarbarorum liber comprises the "original version" written by Erasmus and witnessed only in a manuscript preserved in Gouda. (iv) Later versions are recorded insofar as they still belong to Erasmus' activity. The analysis of editions that do not belong to the horizon of Erasmus' life and activity, as well as contaminations between "authentic" and non-authentic prints are outside the scope of the edition. $(v)$ According to these principles, each editor establishes, after a careful analysis of the circumstances of the redaction and the phases and main features of circulation, his own array of printed versions and, if still available and relevant, manuscripts. This array constitutes the basis of the edition in terms of selected text and sources of variant readings; it, and the stages of the history of the text, are to be described in the introduction.

A concrete example is the edition of the well-known Encomium moriae (Erasmus 1979), a work whose history stretches between 1511, the probable date of the first 
(unauthorised) edition, and 1532, the date of publication of the final version in Basle by Hieronymus Frobenius and Nicolaus Episcopius. It went through several revisions and additions of commentaries, partly by Gerardus Listrius and partly by Erasmus himself. Its editor, Clarence $\mathrm{H}$. Miller, prepared it on the basis of the edition published in 1532. Seven other editions "in which Erasmus had a hand" (in Erasmus 1979, 39) are included (see also the conspectus siglorum on p. 66). They are selected with the main purpose of illustrating Erasmus' activity in reworking the text, and to exemplify all kinds of additions and revisions he made to the original text.

On the other hand, the rather problematic case of the Iulius exclusus, edited in 2013 by Silvia Seidel Menchi (Erasmus 2013; see the introduction, 5-222), a work whose attribution to Erasmus has long been denied, and that circulated in manuscripts before and after the publication of the editio princeps in 1517 (Mainz: Peter Schöffel the Younger), led to different choices. The edition is, in fact, based on Basel, Universitätsbibliothek, A IX 64, namely the manuscript written by Bonifacius Amerbach and completed in 1516. Further witnesses are Basel, Universitätsbibliothek, A IX 64a, written by the same Amerbach, and the editio princeps. The witnesses are chosen according to their closeness to the archetype and to their contribution to the establishment of a fixed, authoritative text that was diffused through print and became the vulgata.

\subsubsection{Girolamo Fracastoro, De sympathia et antipathia liber I}

The critical edition of Girolamo Fracastoro's De sympathia et antipathia rerum liber I published by Concetta Pennuto (2008) is remarkable in several respects. In order to understand this situation better, and to explain the methodology followed by the modern editor, a few words of explanation about the history of the text are necessary (see Pennuto 2008, xiii-xlvii). Girolamo Fracastoro (1478-1553) published the text for the first time in Venice in 1546 (printers: Tommaso and Giovan Maria Giunti). This edition is accompanied, in an appendix, by a list of errata ita corrigenda which did not enter the textual tradition immediately, and consequently did not influence the second and third prints (Lyon, 1550 and 1554; printers: Guillaume Gazeau and Jean de Tournes), but were integrated into the text only in 1555, when a new Venetian edition was brought out by the same Tommaso and Giovan Maria Giunti. This edition did not only, however, include Fracastoro's corrections, but was also marred by several interventions (or, better, by deliberate linguistic manipulation) on the part of its editor, Paolo Ramusio (1532-1600; son of the Arabist Giovan Battista Ramusio). Despite this, the 1555 edition became the reference text, practically erasing the memory of the editio princeps from all other editions (all in all, there are twelve, stretching from 1546 to 1671). Only the Nuremberg edition, published in 1662 as a part of the Theatrum sympatheticum, does not include any changes (i.e. neither the errata nor Ramusio's “improvements") and seems to go back to an "original” without any changes. Thus, the development of the text shows changes, updates, and innovations from several sides: the author, an editor, and the printed texts with 


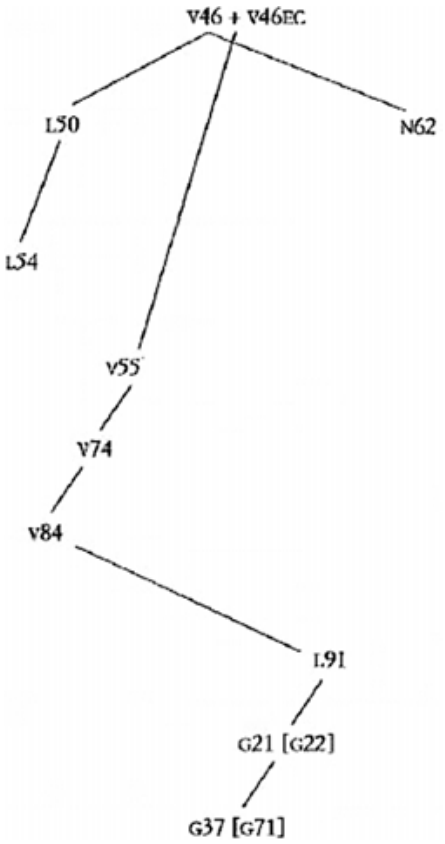

Fig. 7.8-2: Pennuto (2008, lxx).

their own errors and deviations. The consequences of such a state of the tradition for the modern editor can be summarised as follows. (i) She could not limit her work to the reconstruction of the author's original text, for this would be an artificial conflation formed by the text of the editio princeps and the insertion into it of the errata originally included in the appendix. (ii) She could not simply dismiss Ramusio's linguistic manipulations of the text as later interventions and, consequently, leave them out of the edition, for it is not certain whether they were the result of his own work or were inspired by written or oral contact and exchange between him and Fracastoro. Whatever their origin, they are part of the dynamic development of the text; therefore, they must be recorded, at least in the critical apparatus. (iii) As almost every printed copy showed variant readings of its own or, as we have seen in case of the one printed in Nuremberg, a distinctive connection to the editio princeps, the editiones descriptae, or those that could be considered as such, are almost non-existent. Therefore, all editions have to be taken into account. (iv) She could not limit her work to the establishment of a correct text according to one or more selected prints, including in the apparatus only errors and misprints from single editions that undermine the content, but had to put together two different, nonselective critical apparatuses, the first recording the "varianti d'autore" [author's variants] (i.e. the changes made by Fracastoro himself), and the second reflecting the historical development of the text: "un apparato storico evolutivo con le varianti chiaramente non d'autore" [an evolutive critical apparatus with the variants clearly 
not from the author] (Pennuto 2008, xviii). ( $v$ ) Last but not least, she had to produce a stemma editionum representing the textual development graphically (see fig. 7.8-2).

\subsubsection{Editing printed texts beyond prints: Some examples of interaction between prints and manuscripts}

For some editorial projects of Renaissance works, resorting only to printed copies is not enough. For the preparation of such editions, which I call "mixed", the printed version of the work cannot constitute a reliable basis for an edition, because it does not deliver a complete text of the work or comprises one redaction of a work existing in several versions, or because the tradition of the work is also partially made up of manuscripts. In the following examples, I will simply sketch the methods followed by three scholars for integrating both printed copies and manuscripts in a single editorial project.

\subsubsection{Bernardino Telesio, Varii de naturalibus rebus libelli}

The first example is the edition of some minor works written by Bernardino Telesio (1509-1588) on subjects of natural philosophy (especially Aristotelian meteorology and biology), such as comets, the sea, lightning, colours, tastes, and respiration, published by Luigi de Franco (1981). These works (De cometis et lacteo circulo, De mari, De fulmine, Quod animal universum ab unica substantia gubernatur, Contra Galenum, De usu respirationis, De coloribus, De saporibus, and some others) were not unknown, as most of them had already been included in the 1590 printed edition supervised by Antonius Persius. Some others, neglected by Persius, had been made available as appendices in Francesco Fiorentino's book on Telesio's conception of nature (Fiorentino 1872-1874). Finally, the De colorum generatione had been published independently by Telesius (1570).

Almost all the works are preserved both in manuscripts (some of which are autographs) and in prints. In addition, they exhibit various stages of composition: minutae and sketches - which were sometimes later revised, with corrections introduced in the printed copy presented to the revisore ecclesiastico in order to obtain the imprimatur (de Franco 1981, xxi) - as well as final prints (de Franco 1981, xxxixlvii).

In this distinctive case, the editor's task was twofold: to establish a critical text and to represent the genesis and the development of the work from scratch to its final shape (de Franco 1981, xliii). I cannot discuss all the texts edited by de Franco and their methodologies here, and point only to two specific cases, those of the De mari and the Quod animal universum. The former work is preserved in five manuscripts and in two printed editions, both published in 1570, one including it in the anthology supervised by Persius, the other containing it independently. Of the five manuscript witnesses, the most relevant ones are the two drafts preserved in Napoli, 
Biblioteca Nazionale, VIII.C.29. The first draft is the autograph submitted to the revisore ecclesiastico; it preserves a first redaction with some corrections. The second draft is, in fact, the final version, and corresponds to the text printed independently in 1570. The printed text edited by Persius adds three chapters compared to the previous version, which also figure as sketches (minutae) in the autograph copy. This situation led the modern editor to choose the independent print of 1570 as the basis for the edition and the Persius edition as the basis for the three added chapters, and to edit the text of the first draft as an appendix.

The second case, the Quod animal universum, is apparently simpler, but by no means less interesting (de Franco 1981, 1-li). The work is preserved in print only thanks to Persius' edition. It might have circulated in manuscript form, but no copy of the complete text has survived. The printed text, however, cannot be considered a reliable basis, for it is disfigured by errors and unclear formulations as well as by further mistakes added either by mechanical factors or by unfortunate conjectures made by Persius in an attempt to improve the quality of the edition. Facing such a situation, the modern editor had to turn to the minutae preserved in two manuscripts (Città del Vaticano, Biblioteca Apostolica Vaticana, Ottob. Lat. 1929 and Città del Vaticano, Biblioteca Apostolica Vaticana, Ottob. Lat. 1306) to restore the disfigured passages and reconstruct a reliable text.

\subsubsection{Anonymous, Cinq-cent rondeaux d'amour}

In 2011, Françoise Féry-Hue published a new edition of an anonymous work sometimes attributed to Pierre Gringore (1475-1538/39), the Cinq-cent rondeaux d'amour, written during the first decades of the sixteenth century, whose origin can perhaps be placed at the court of Angoulême, as the dedicatory letter addressed to Francis I of France shows (Féry-Hue 2011). By using the metrical form of the rondeau and the fashion of short versified letters, the author tells a tragic love story that ends with the death of the lady and the retirement of her lover to a monastery. The purpose of the work was possibly to provide members of the court with material for private reading and spiritual cultivation; the destiny of the work was, however, different, for the print probably helped to widen its reception and to enlarge its audience. The Cinq-cent rondeaux is handed down by five sixteenth-century manuscripts $(C$ : location unknown, Collection Particulière; $F$ : Paris, Bibliothèque nationale de France, fr. 19183; R: Paris, Bibliothèque nationale de France, Rothschild 2855; L: Den Haag, Koninklijke Bibliotheek, 129.G.20; S: Soissons, Bibliothèque Municipale, 204), and was printed ten times between 1527 and 1550. The edition of the work is based on the Soissons manuscript, used as base text. But all other manuscripts were collated and used to improve the text, and their variant readings were recorded in the apparatus. Moreover, the editor offers, synoptically, a transcription of the text of the editio princeps published in Paris in 1527 (printer: Alain Lotrain). This editorial decision can be explained by the complicated tradition of the text, which did not allow the editor to draw a convincing stemma. Moreover, the editor wished to emphasise the 
development of the text and its dynamics, to show how it moved from a limited courtly readership in manuscripts towards a larger audience in print, and how both external and internal features of the two forms of dissemination contributed to shaping this dynamics. In this context, the printed text, as represented by the editio princeps, does not simply represent the end of the manuscript tradition and the beginning of a new way of disseminating the text, but is also one of the main steps in the dynamics leading towards the transformation of that text and of its perception.

\subsubsection{3 lacopo Ammannati Piccolomini, Lettere}

The case study represented by the edition of Iacopo Ammannati Piccolomini's Lettere (Cherubini 1997) describes a more complex form of interaction between manuscripts and prints, and, above all, a different perception of printed version(s) compared to the codices. More specifically, it shows that the inclusion of manuscripts and prints in the same editorial enterprise is necessary for reconstructing the complete corpus of writings of the author, and that the perception of a printed text in such a project does not always correspond to our impression that the print represents a moment of fixation and consolidation of a tradition. Again, in order to make readers aware of the reasons determining the editor's choices and methodologies, some further information about the text and the edition should be provided. Iacopo Ammannati Piccolomini (1422-1479) had intended to commission and publish a collection of his own letters, but was prevented from doing so by his death. His friend and secretary Iacopo Gherardi took up the task of collecting, ordering, revising, and publishing the letters in a collection, but the editio princeps he managed to publish in 1506 in Milan (Piccolomini 1506), was incomplete and not satisfactory. This edition (Cherubini 1997, 1:25) was later used as a basis for further printed editions (the last of which was printed in Frankfurt in 1614; on the prints, see Cherubini 1997, 1:58-76), each of which was incomplete compared to the editio princeps, containing only parts of the epistolary production of Piccolomini. On the other hand, groups of letters handed down in the form of minutae and copies had already started to circulate independently in small manuscript collections (Cherubini 1997, 1:26-58). Facing such a situation, Paolo Cherubini, who published an edition of all the letters written between 1444 and 1479 found to date, not only had to gather together a complete corpus of the letters (found in different stages of composition) but also had to catalogue prints and manuscripts and to understand their relationships. Consequently, he edited, according to chronological principles, letters preserved either in single copies or in various copies in different forms and stages of completion.

One example is Epistula 17 (Cherubini 1997, 1:363-368), a moral treatise written in the form of a letter sent by Piccolomini to himself on December 18, 1461, after he had been made cardinal by Pius II. This letter is witnessed both by Salamanca, Biblioteca de la Universidad, ms. 2109, and by the printed editions published in 1506 (namely the editio princeps) and in 1614 in Frankfurt (in officina Aubriana). In 
this case, the modern editor reproduces the text according to the printed copies, and records the variant readings of the Salamanca codex in the critical apparatus.

The interaction between manuscripts and prints, between different forms of collection, and between different compositional stages of the individual letters influenced, together with variant readings, the stemmatological representation of their mutual relationships. Clearly, it was not possible to draw a single stemma codicum, nor does it seem that the editor intended to have one. Rather, he structured the numerous manuscript collections into groups or clusters according to the common elements they shared and the innovations they showed in comparison to what could be considered their models.

The situation that the editor of Ammannati Piccolomini's letters had to face is not an exceptional one. Other editors of collections of letters have had to develop similarly flexible strategies for representing the relationships between manuscripts and printed witnesses, and for editing the texts. The recently completed edition of Joseph Justus Scaliger's Epistulae (Botley and van Miert 2012; see also the Web version, emlo-portal.bodleian.ox.ac.uk/collections/?catalogue=joseph-justus-scaliger) clearly shows that its editors, Paul Botley and Dirk van Miert, had to edit different kinds of material, sometimes overlapping. The same letters were often transmitted through multiple copies, both as manuscript and in printed form, with different statuses: autograph letters, authorial drafts and copies, and so on.

\section{Further reading}

For a general assessment of the cultural importance of early printed editions, see Feld (1978) and Pettegree (2011). The following two handbooks of textual criticism offer insights into the methodology of editing early printed books: Stoppelli (2008) and Stussi (2015); see also Trovato (2017).

\subsection{Genetic maps in modern philology}

Dirk van Hulle

The notion of the stemma is a metaphor (see 2.2.2). Like all the "metaphors we live by" (Lakoff and Johnson 1980), this metaphor of the family tree is indicative of a particular way of thinking - in this case, of an ideology that inherits the fixation on "purity" of the textual "bloodline". In this sense, the genealogical method sometimes seems to reflect an ancient or mediaeval obsession with pedigree, combined with a nineteenth-century preoccupation with origins. In modern times, however, the problem is usually not the lack of an original autograph, but rather the abundance thereof. And among this abundance, the problem the early twentieth-century 
textual critics were faced with was choosing the most authoritative text. This section therefore starts with a brief historical background, discussing the tensions between two schools of scholarly editing that have determined much of the debate in modern-day textual scholarship, the German and the Anglo-American traditions. This historical background is followed by a discussion of two notable trends. First, a development from schools or traditions to "orientations to text” suggests a less prescriptive and less biased understanding of the discipline. A second notable trend is the development from a focus on (final) authorial intention to an openness to multiple intentions, which becomes especially manifest in sister-disciplines such as genetic criticism. This openness to multiple intentions implies an increased awareness of other agents of textual change. The section's central question relates to the suitability of the notion of the stemma when it comes to mapping the genesis of a text.

\subsubsection{The tensions between Anglo-American and German editorial traditions}

The British bibliographer Ronald B. McKerrow $(1939,7-8)$ defined the most authoritative text as "that one of the early texts which, on a consideration of their genetic relationship, appears likely to have deviated to the smallest extent in all respects of wording, spelling, and punctuation from the author's manuscript". It is interesting to note that McKerrow used the adjective "genetic" long before the emergence of "genetic criticism" in France in the second half of the 1960s (see below). McKerrow worked with the notion of an "ideal text", which "should approach as closely as the extant material allows to a fair copy, made by the author himself, of his plays in the form which he intended finally to give them" (McKerrow 1939, 6). Final a u th orial intention was the governing principle, and it remained so for several decades. In 1951, Walter Wilson Greg (1951, x) defined his first rule as an editor as follows: "The aim of a critical edition should be to present the text, so far as the available evidence permits, in the form in which we may suppose that it would have stood in a fair copy, made by the author himself, of the work as he finally intended it." In his second rule, he defined the copy text as the most authoritative text of the early prints (Greg 1951, xii). In addition to final authorial intention as a guideline, giving the editor the freedom to make an educated guess as to what this intention was, the fixation on purity persisted.

When, building on McKerrow and Greg, Fredson Bowers further developed the "copy-text theory", he defined "the aim of textual criticism" as "the recovery of the initial purity of an author's text and of any revision (insofar as this is possible from the preserved documents), and the preservation of this purity despite the usual corrupting process of reprint transmission" (Bowers 1970, 30; my emphasis). The notion of purity in Bowers's definition is symptomatic of the then-dominant view, which almost automatically regarded textual agents other than the author as introducers of textual "corruption" in the sense of an intrusion into the text as the author wanted it to be, and thus as impeding realisation of the author's intention. 
Because the notion of purity was linked to the author's final intention, this created a tension with Wimsatt and Beardsley's influential essay "The Intentional Fallacy” (1946). The growing sentiment against intentionalism in literary studies led to counter-narratives such as Eric Donald Hirsch's Validity in Interpretation (1967). But the debate itself seemed to suggest that there was an underlying assumption in both camps that the text is what the author wanted to write. As G. Thomas Tanselle noted in "The Editorial Problem of Final Authorial Intention" (1976, 171-172), "the question of the bearing of authorial intention on interpretation would hardly arise unless the text is assumed to be what its author wished". From the perspective of textual scholarship, this assumption is not self-evident. The copy-text theory allows the editor to choose readings from different versions in order to establish a text that reflects the author's final intention.

From the perspective of German editorial theory, the copy-text approach resulted in what was critically dubbed "an eclectic (contaminated) text" (Zeller 1975, 237). This criticism was voiced by the Swiss editorial theorist Hans Zeller, one of the most eminent representatives of the historical-critical edition and the German school of scholarly editing. Although his criticism opposed Bowers's eclectic approach, Zeller's notion of contamination again suggested a form of corruption, an impediment to purity, albeit a different kind of corruption and a different kind of purity. For what Zeller referred to was the "contamination" of the integrity of the text in a historical document. Criticising the assumption that "the sum of authoritative readings yields an authoritative text" (Zeller 1975, 137), he argued that an "eclectic editor contaminatingly synchronizes that which occurred diachronically", thus creating a text that has never existed before, "in the name of authorial intention" (Zeller 1995, 106). One of the most remarkable (post)modern editions of a modernist text that epitomised this debate was the 1984 edition of James Joyce's Ulysses by Hans Walter Gabler, Claus Melchior, and Wolfhard Steppe. This edition combined elements from both the German and the Anglo-American traditions of scholarly editing, and gave rise to a long controversy, partly because it confronted both these editorial traditions with their respective orientations to text. Because it tried to reconcile the reality of the historical documents with the ideality of the author's intention, it has been called "the climax of the traditional method" (Sahle 2013, 129).

\subsubsection{From schools or traditions to orientations to text}

The notion of purity gradually lost currency. This trend was, to some extent, facilitated by authors themselves. To illustrate this phenomenon, the Irish writer Samuel Beckett is a good example. Like many authors, Samuel Beckett was sensitive to changes in transmission and unsolicited modifications to his texts. This sensitivity, however, did not relate to purity but to integrity, in the etymological sense of "entirety" (from Latin integer, "whole"), that is, including all the impurities as well. 
With reference to the play Endgame, Beckett actually tried to protect his text "in all its impurity" (to Alan Schneider, February 6, 1958, Beckett 2014, 103; my emphasis). This was his reaction against the attempts by the British censor, the Lord Chamberlain, to remove the line referring to God with "The bastard, he doesn't exist." A similar form of censorship had been applied to Waiting for Godot. The first British edition (Faber and Faber, 1956) had been expurgated by the Lord Chamberlain. Almost ten years later, in 1965, Faber and Faber decided to bring their version "closer to the original", and Beckett hoped the "integral" text would now be treated less "puritanically" (to Charles Monteith, November 15, 1963; Beckett 2014, 580).

Obviously, the recovery of a text's integrity is just as vague as what Bowers called "the recovery of the initial purity of an author's text". To provide more clarity, it is important to distinguish between the elemental material and forces involved in the production, revision, and dissemination of literary works. These elements are material, causal, temporal, genetic, commercial/aesthetic, and performance-related. The relative importance one attaches to these elements determines one's o ri en ta tion to text. Peter Shillingsburg originally defined five orientations (documentary, sociological, authorial, bibliographical, and aesthetic) in Scholarly Editing in the Computer Age (1996). They were recently revised to add a "genetic orientation" and fine-tune the other orientations (van Hulle and Shillingsburg 2015). These orientations relate to the different ways of framing the narrative of the genesis, revision history, and publication of a text. They are conceived as a descriptive, not a prescriptive framework. There are no "right" or "wrong" orientations. The central issue is simply consistency: the framework helps determine one's orientation and, no matter which orientation one chooses at the start of a project, the trick is to apply it consistently.

(i) If one's focus is on the documentary evidence, the orientation is m at erial, because, from this perspective, textual authority resides in the extant documentary material evidence. This material orientation can be subdivided into a bibliographical and a lexical approach. The bibliographical approach considers the visual, tactile, physical, or iconic aspects of the material document so important that it becomes logically impossible to replicate or emend it. The lexical approach does allow the text of a document to be replicated, but emendation is logically not allowed since the document is regarded as the ultimate textual evidence. The German model of the historical-critical edition sometimes does emend obvious errors (Textfehler), but that is, strictly speaking, a non-materialist intervention.

(ii) If an editor focuses on the involvement of every agent of textual change (not only the author but also any other agent involved in the composition, revision, and production of texts), the orientation is c a u sal. This causal orientation is a continuum between an authorial and a social approach. The question is whether the interventions by all agents of textual change are to be valued equally. The a u thorial approach focuses on the text created and/or desired by the author; the social approach concentrates on the text created in concert with all the production staff 
involved. In the latter case, authority resides in the institutional unit of author and publisher.

(iii) If the moment when a text was produced is the central concern, the orientation is temporal. If there are elements in the text that do not fit the period of its production, this will be a criterion for emendation. From this perspective, authority resides in periods of inscription or reinscription. This orientation can be divided into a production-oriented and a diachronic approach. The production-oriented a p proach views the work as a series of snapshots, each fixed more or less well in a document, whereas the diachronic approach regards the work as a creative development. For this orientation, the central issue is not the document but either the "moment in time" or the "sequence of development". The record of these two forms of temporality (captured in a document) can be faulty, so the logic of this approach allows the editor to emend the text.

(iv) If one is mainly interested in the dynamics of the composition as implied by the extant versions, their chronology, and the changes within (deletions, additions, substitutions) and between them (variants or rewritings), the orientation is g e net ic. Its focus is on the actions and trajectories of creative invention as implied by the chronological succession of textual changes, which is different from material orientation (for which authority resides in the document) and from temporal orientation (for which authority resides in periods of inscription or reinscription). The genetic orientation not only investigates endogenesis (the succession of draft versions) and epigenesis (the continuation of the creative process after publication), but also ex o g e n es is (the interaction with external source texts), which may result in editions that include the reconstruction of an author's personal library.

$(v)$ If the editor wishes to pay special attention to the tension between a play's stage directions and its actual performance, this focus on performance constitutes a separate orientation, which becomes all the more important in the case of postdramatic theatre.

(vi) If editors choose to modernise or revamp a text based on their subjective aesthetic preferences, or if they try to respect the known aesthetic principles of an author or of a historical publisher, the orientation is aesthetic.

For a more elaborate discussion of these orientations, see van Hulle and Shillingsburg (2015).

\subsubsection{Stemmata and genetic maps}

Given this variety of orientations, the notion of textual purity becomes increasingly problematic. And, whether one wishes to speak of textual "purity" or "impurity", the question is whether the stemmatological method works for modern texts in the way it does for older texts. One of the defining elements of philological practices in modern times is the relative abundance of autograph manuscripts or other (also 
digital) documents pertaining to the genesis (rather than the transmission) of texts. Still, this abundance is only relative, for manuscripts are "poor" material, according to Hans Magnus Enzensberger. In Die Entstehung eines Gedichts (1962), he distinguishes two approaches to a poem's genesis: from the inside and from the outside. The former can only be applied by the author, who has the advantage but also the disadvantage of hindsight, for memory tends to distort the past. The latter approach can only work with what Enzensberger calls "unequivocal" (eindeutig) but "poor" material, because no memories are attached to it. This was the case with the manuscripts of Heinrich Heine when they were acquired by the Bibliothèque nationale de France and Louis Hay was charged with their examination. This was the start of genetic criticism. Although the term was coined in the 1970s, the idea behind it was formulated by Louis Hay (1967) in the French newspaper Le Monde. Hay speaks of two ways of reading, vertical (across versions) and horizontal (following the narrative sequence). These two forms of reading should not be confused, he suggests, but their results might be mutually enriching and elucidating. This vision was developed in the subsequent decades. The research object of genetic criticism is the creative process. In spite of its abstract nature, this objective requires the examination of concrete documents. And, in spite of what Enzensberger claims, these material traces are not always unequivocal and involve quite a bit of interpretation. From this material, genetic critics infer the dynamics of the writing process.

Given the importance of material traces as a starting point of genetic criticism, Pierre-Marc de Biasi conceived his basic model of the average writing process as a typology of documents (de Biasi 1996). Central in this model is the "pass for press" moment (bon à tirer, i.e. the moment the author decides that all is set for printing). In general, de Biasi distinguishes three different phases of the writing process: pre-composition (exploration, documentation, reading, note-taking, conceptualisation), composition (textualisation, drafts, typescripts, revisions), and post-composition (publication history, performance history, self-translations).

The notion of the ste $\mathrm{m} \mathrm{m}$ a is not (or very rarely) used in genetic criticism. Some scholars, however, do apply it to the genesis of literary works. A good example is Ruby Cohn's (2001, 220) “stemma” of the genesis of Samuel Beckett's Fin de partie/ Endgame. Cohn disagrees with other Beckett scholars, such as Giuseppina Restivo, about the "origin of the stemma". In "The Genesis of Beckett's Endgame”, Restivo $(1994,85,88)$ had suggested that a few early sketches in the Sam Francis Notebook were the "core" and the "basis" of the play. The notebook contains two dialogues between "A" and "B" (University of Reading, MS 2926, f. 6r-10r, 11r-20r) and one dialogue between " $X$ " and his factotum " $F$ " (f. 23v-48r). Restivo's thesis is that the $\mathrm{A}-\mathrm{B}$ dialogues and the $\mathrm{X}-\mathrm{F}$ dialogue in the Sam Francis Notebook together form the "two different starts" (Restivo 1994, 85). Ruby Cohn's alternative "stemma” for Fin de partie/Endgame differs from Restivo's “line of development” (Restivo 1994, 93), and deviates from the descriptions in the catalogue at the University of Reading, in that not all fragments that are catalogued as early versions of Fin de partie are included in the "stemma". 


\section{Genetic Map of Fin de partie}

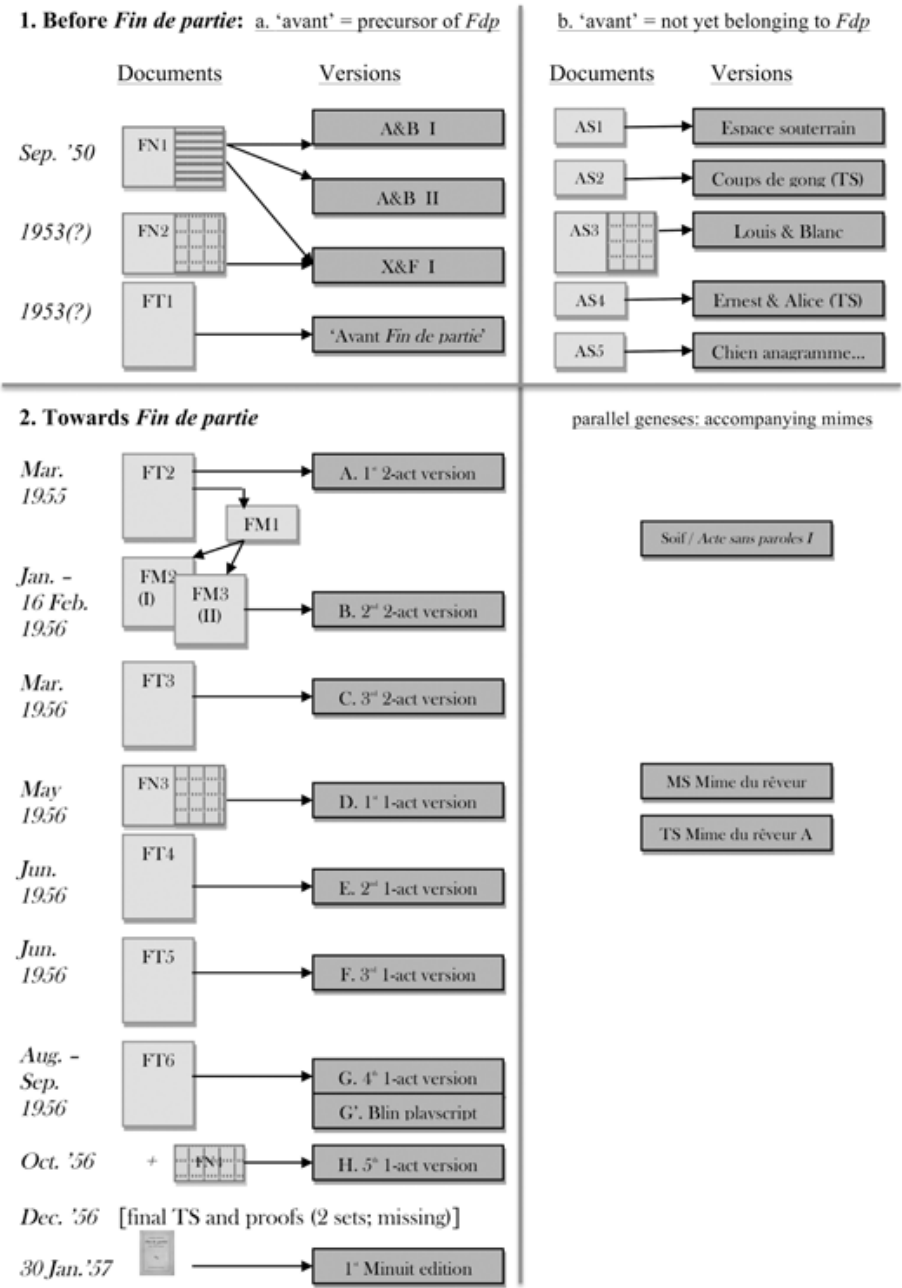

Fig. 7.9-1: Genetic map of Samuel Beckett's Fin de partie. Source: Beckett Digital Manuscript Project (beckettarchive.org/findepartie/about/chronology).

The question is whether this arboreal model is suitable for reconstructing a work's genesis. To begin with, an arboreal model suggests a "seed" as the beginning of the writing process. This metaphor is often used in literary criticism, but, as Restivo's idea of "two different starts" suggests, the reality of actual writing processes suggests that literary geneses seldom grow from one single "seed". Creativity is often sparked by a combination of numerous sources of inspiration, including a writer's personal library. But, even if one leaves exogenesis out of the equation, endogenesis does not always start in one single draft. Moreover, the arboreal model would imply 
two directions of growth from the seed, with not only a stem and branches, but also roots reaching down underground.

It might therefore be wise to work with less organic metaphors and to reconstruct the trajectory of the creative process by means of a map (fig. 7.9-1). The "g e netic map" of Fin de partie in the Beckett Digital Manuscript Project works with Samuel Beckett's own notion of "Avant Fin de partie". This is the name Beckett gave to one of the typescripts (FT1), which he donated to the University of Reading (MS 1227/7/ 16/7). The notion of "avant" [before] points to a crucial question of genetic criticism: where the avant-texte of a particular work starts. Between the completion of the antecedent play, En attendant Godot, and Fin de partie, Beckett wrote several dramatic fragments that can all be called "before Fin de partie"; but then we have to make a distinction between "before" in the sense of a precursor of Fin de partie and "before" in the sense of "not yet belonging to Fin de partie" (because some of the dramatic fragments do not contain any significant characteristics of the published version of the play). Nonetheless, even in the latter case, the trials and errors that did not lead directly to a successful publication did indirectly contribute to the creative process. They would not belong to a "stemma", but they do have a place on a "map".

The genetic map also makes a distinction between documents (which have material substance) and ver si o n s (which are a conceptual abstraction). One notebook (e.g. French notebook 1, FN1) can contain two early versions of the play and, vice versa, one version (e.g. the second two-act version) can be so long that it was written in two documents (FM2 and FM3, which were separately sold and ended up on two sides of the Atlantic, at Ohio State University and Trinity College Dublin respectively).

\subsubsection{From final authorial intention to multiple intentions}

What genetic maps show, above all, is that authors' intentions can be highly changeable, to the extent that several genetic critics no longer see the writer as a monolithic "self" but as a succession of selves. The writer who cancels a word is already different from the one who wrote it. This interval opens up the space in which genetic criticism operates, according to Nicholas Donin and Daniel Ferrer $(2015,24)$. It is not only genetic critics who stress the fluidity of the text in modern times. When John Bryant developed his "fluid text" theory, he no longer referred simply to (final) authorial intention but to "an announced notion of intentionality" in defining the critical edition as

a genre of scholarly editing in which a text is constructed usually after the inspection, and sometimes the conflation, of significant versions of the work; it is also a text that is invariably emended along certain principles so as to bring it closer to an announced notion of intentionality. (J. Bryant 2002, 20) 
In the twentieth century, the notion of "intention" became such a taboo that critics increasingly eschewed the term. But, in scholarly editing, the notion cannot be avoided. Instead of steering clear of the term, textual scholars have sought to define it more clearly and suggested a distinction between what authors intended the text to mean and what they intended the text to do (i.e. what character or punctuation mark was intended to be inscribed; Shillingsburg 1996, 36-37). The latter type of intention is what textual scholarship usually has to deal with, and therefore the subjectivity involved in the critical act of determining an author's intention is "hedged in at every point by whatever can be ascertained or inferred about the history of the work's writing and early production”, as Paul Eggert notes $(2013,104)$. In this sense, it may also have been one of the author's intentions to leave all matters of spelling and punctuation to the copy-editor at the publishing house. A famous example is Jane Austen, who relied on her publisher to correct her spelling mistakes, as Kathryn Sutherland pointed out (see Garner 2010). The help of a copyeditor can take on such proportions that a writer's "typical" style eventually turns out to be the work of someone else, as in the case of Raymond Carver and Gordon Lish. The author of the short-story collection What We Talk About When We Talk About Love is famous for his minimalistic writing style. But this style is actually, to a large extent, the work of his editor, Gordon Lish, who was fiction editor of the magazine Esquire from 1969 to 1977. Lish's papers (in the Lilly Library at Indiana University in Bloomington) show how drastically he pruned as an editor, sometimes even rewriting some of Carver's stories. For instance, the story "If It Please You" was so thoroughly rewritten that, according to Stephen King (2009), it is "a total rewrite, and it's a cheat". But others see Lish as a crucial agent of textual change who was instrumental in creating the Carver style in the first place. In 1971, he edited Carver's story "Neighbors" for publication in Esquire, making so many cuts that it resulted in the minimalist effect for which Carver is famous. For the Collected Stories, published in 2009, Carver's widow printed some of the stories in both the author's version and the version edited by Lish (see Lorentzen 2015). This practice does not represent two "schools" or "traditions" of editing. Instead, it shows two orientations to text at work. Within the causal orientation, Stephen King's attitude as a creative writer understandably belongs to the authorial approach; the edited version represents the social approach.

In conclusion, philological practices and editorial theory in modern times show a development from "purity" to "fluidity" and an increased awareness of other agents of textual change. These agents often play a role in the multiplicity of changing authorial intentions and thus in the creative process, which continues even after a text's first publication. This field of epigenetics is the common ground where traditional schools of scholarly editing and genetic criticism can meet and mutually benefit from each other's perspectives. What this mutual exchange of ideas could yield is a re-evaluation of the notion of the stemma when it comes to mapping a text's (endo- and epi-)genesis. 


\section{Further reading}

Readers who would like to know more about the development of critique génétique, especially in France, can be referred to Grésillon (1994), de Biasi (2000), Ferrer (2011), and van Hulle (2014). A useful collection of articles on the topic is to be found in de Biasi and Herschberg Pierrot (2017). Ferrer (2002, 2016) offers insights about the relationships between genetic criticism and textual criticism in general. Van Hulle and Shillingsburg (2015), already cited above, is an introduction to what is meant by "orientations to text". 